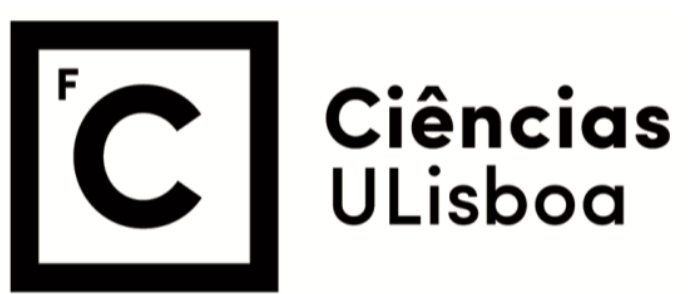

\title{
Using Games to Practice Screen Reader Gestures
}

Gonçalo Miguel Monteiro Ferreira Barras Lobo

Mestrado em Engenharia Informática

Especialização em Engenharia de Software

Dissertação orientada por:

Prof. Doutor Tiago João Vieira Guerreiro

Prof. Doutor André Filipe Pereira Rodrigues 



\section{Acknowledgments}

First of all, I would like to thank to my thesis advisors Doctor André Rodrigues and Doctor Tiago Guerreiro for all the guidance through the journey that is the master degree. I would not have been able to complete this without their help and advice. I would like to thank my family as well, for supporting me throughout this phase of my life, from the moment I entered FCUL to this moment in which their support has been absolutely vital to my life and for giving me the opportunity to pursue my goals. My family will always be a source of motivation in my life.

To Liliana, my girlfriend that accompanied throughout my academic life and is always there for me, as an incredible source of motivation to chase my dreams and to challenge myself every day. To the colleagues who have been by my side from the first year and the colleagues I have met along the way that have provided me with supporting words, memorable memories and helped me with my academic pursuits, particularly Nuno Duarte. Also, a special thank you to Eduardo who has been a close friend for my whole life and has provided me with incredible support.

I would like to also thank FCUL, for being the place in which I was able to have the conditions and opportunities to reach my academic goals for the last eight years. Thank you also to Lasige research group, that received me with open arms and provided me with the tools, opportunities and guidance to succeed. A special thanks to David Gonçalves for helping me contact the volunteers that have participated in the development of this thesis.

Last but not least, to the Fundação Raquel and Martin Sain and Associação Promotora do Ensino dos Cegos (APEC) and for everyone who participated in my study as for without them and without their time this work would not have been possible. 

To my grandparents. 



\section{Resumo}

Os telemóveis hoje em dia são considerados uma extensão da nossa vida pessoal e social. Passaram de uma ferramenta que apenas fazia funções simples como fazer chamadas e enviar mensagens para uma ferramenta que permite comunicar com colegas e amigos a partir de qualquer lugar, permite consultar qualquer tipo de informacão e tornaram-se também num método de entretenimento através de música, vídeos ou jogos.

Os sistemas operativos móveis mais populares, Android e iOS, têm vindo a desenvolver e a melhorar as opcões de acessibilidade e incluem os mesmos tipos de funções: reconhecimento da fala, zoom, fontes maiores e os leitores de ecrã. Os leitores de ecrã oferecem um conjunto de gestos e uma interface que lê o conteúdo do ecrã e permitem navegar pelo telemóvel e aceder às várias aplicacões, que poderão ou não estar otimizadas de modo a acomodar este tipo de acessibilidade.

Enquanto que para alguns utilizadores a utilização destes gestos é mais fácil, para utilizadores menos experientes a sua utilizacão pode ser mais complicada, pelo facto de estes disponibilizarem um conjunto de gestos de interacão cuja utilizacão pode ser mais confusa e por obrigar a conhecimento prévio da interface ou a explorar todos os seus elementos em busca do elemento que pretendem. Para além disto, o processo de aprendizagem de gestos para utilizadores menos experientes pode ser entendido como entediante uma vez que nenhum dos métodos inclui uma componente lúdica, através da qual seja possível aprender um gesto ou um movimento de maneira mais agradável e é um processo muito dependente de tentativa e erro, na qual os utilizadores vão descobrindo um gesto em específico à medida que precisam da funcionalidade que o gesto oferece.

A criação de jogos acessíveis e a acessibilidade nos jogos são temas que têm suscitado muito interesse nos últimos anos através da existência de plataformas online nas quais investigadores, developers e jogadores podem partilhar experiências. Os jogos são uma forma de entretenimento que fomenta o treino e a repeticão de gestos, movimentos ou padrões que podem ser aprendidos, melhorados e memorizados. Também são uma maneira de interagir socialmente e de criacão de relações e contactos com outros utilizadores que joguem os mesmos jogos e experienciem as mesmas dificuldades.

Os jogos são populares devido ao elevado grau de interação que têm. Estes oferecem uma interação na qual as escolhas dos jogadores influenciam o resultado do jogo. Para além disso, têm demonstrado ter vários benefícios para a saúde, como o alívio de stress, 
educação e bem-estar social. No entanto, alguns jogos não são totalmente acessíveis ou a sua jogabilidade não oferece opções acessíveis e por causa disso, pessoas com algum tipo de deficiência visual poderão não conseguir aproveitá-los ao máximo e acabam por experienciar uma jogabilidade limitada ou muito diferente da normal. Neste sentido, os jogos acessíveis tornam-se interessantes para jogadores cegos ou com algum tipo de deficiência visual, uma vez que são uma solução para o facto de estes não poderem jogar os jogos mais convencionais.

Nesta tese apresentamos Games for Gestures, um conjunto de três jogos acessíveis: Foguete, Guarda Redes e Corda. Estes jogos acessíveis permitem aos utilizadores descobrirem e treinarem o conjunto de gestos que é oferecido pelo Google Talkback e com a criação destes jogos queremos entender se poderá ser possível melhorar a acessibilidade e combater os problemas descritos anteriormente com a criação de jogos acessíveis para o telemóvel, que se foquem em ensinar e praticar um ou um conjunto de gestos corretamente, de forma a obter o resultado pretendido.

Os jogos que desenvolvemos permitem aos utilizadores treinarem um gesto específico à sua escolha, de forma a poderem melhorar os seus resultados e entender qual será o resultado esperado desse gesto na utilização normal do seu smartphone. Para além disso, os jogos têm a capacidade de explicar ao utilizador o gesto que está a fazer através de um sistema em que lhe é oferecido feedback visual e audível sobre o gesto que está a executar e assim permite entender como a execução do gesto pode ser melhorada.

O jogo Foguete é baseado no jogo de arcada clássico Asteroids, no qual o jogador se encontra num ambiente onde está a controlar uma nave espacial pelo espaço e o objetivo é o de desviar dos vários tipos de inimigos, cuja função é embaterem na sua nave. Este jogo foca-se nos swipes direcionais para a esquerda e para a direita e em ensinar a navegação Swipe To Explore. O jogo Guarda Redes introduz o jogador num ambiente de equipa de futebol, no qual desempenha o papel de guarda-redes e o objetivo é o defender o máximo de remates possíveis da equipa adversária. Este jogo foi desenvolvido tendo em consideração utilizadores mais experientes, por isso foca-se nos gestos mais avançados que o Google Talkback oferece, como os gestos angulares e os gestos para a frente e para trás, através de dois modos de jogo. O último jogo que desenvolvemos, Corda, coloca o utilizador num ambiente em que está a brincar com várias crianças a saltar à corda e o objetivo é o de saltar o maior número de vezes sem perder. Este jogo tem como foco ensinar o gesto do duplo-toque e principalmente o tipo de navegação Explore By Touch.

Para avaliarmos o desempenho dos jogos produzidos realizámos um estudo com 6 pessoas cegas ou com algum nível de deficiência visual e com diferentes níveis de experiência no smartphone, no qual pedimos para jogar cada um dos nossos jogos, num periodo de 5 dias. Após este período conduzimos entrevistas remotas gravadas com cada um dos participantes em que são feitas um conjunto de perguntas relacionadas com a sua experiência a jogar os nossos jogos, com o seu processo de aprendizagem de gestos e de 
navegação e quais os métodos que utilizaram para tal, com o seu conhecimento sobre gestos e qual é sua a percepção sobre utilizar jogos para ensinar utilizadores de smartphone a aprender os gestos, principalmente utilizadores menos experientes.

Os nossos resultados sugerem que os jogos produzidos produzimos combatem uma falha que existe em termos de jogos acessíveis, visto que foram bem aceites e os participantes explicaram como existe pouco conteúdo semelhante, principalmente para telemóvel. Para além disso, os participantes demonstraram uma grande vontade em oferecer feedback de como os tanto os nossos jogos como os jogos acessíveis em geral jogos podem ser melhorados, de forma a torná-los ainda mais interessantes e de os partilhar entre amigos e família. Para além disso, os nossos resultados sugerem que os jogos acessíveis poderão vir a fazer parte de um conjunto de métodos utilizados para aprender gestos, sobretudo para utilizadores menos experientes, uma vez que são capazes de oferecer uma componente de entretenimento a um conjunto de métodos que não a tem e que por não a ter são entendidos como aborrecidos, levando a uma aprendizagem que poderá não ser nem a melhor nem a mais rápida.

Por fim, os nossos resultados também sugerem que o processo de aprendizagem de gestos também pode ser melhorado e esta melhoria pode influenciar aspetos como a autonomia e a inclusão em ambientes sociais, principalmente para utilizadores menos experientes, assim como a capacidade de identificar, experimentar e escolher outros tipos de tecnologias acessíveis face a outras tecnologia existente.

Palavras-chave: Acessibilidade, Smartphone, Jogos acessíveis, Gestos, Screen-Readers 



\begin{abstract}
Nowadays, a smartphone is fundamental for multiple aspects of our lives. These have evolved from a basic tool to communicate to a multi-purpose tool that allows to communicate with colleagues and friends and to get any information or entertainment.

Android and iOS, the most popular mobile operating systems, have developed built-in screen readers that make smartphones generally accessible to blind people using gestures and help them use more of their smartphones. However, users experience difficulties due to unfamiliarity with the gestures and due to lack of interaction with their touchscreens.

One possible way to improve the accessibility of these technologies could be through games that can teach how to perform a gesture correctly and explain how it can be used, as lately there has been a growing interest on using video games as an innovative educational tool.

We developed Games for Gestures, a set of accessible games to discover and learn the gestures Google Talkback offers and our goal is to explore whether it is possible for mobile accessible games to be used as a gesture discovery and practice method. Corda focuses on teaching how to navigate with Explore by Touch. Foguete focuses on directional swipes left and right and on teaching Swipe To Explore. Guarda Redes is focused on the more advanced gestures.

To evaluate our games, we performed a study in which participants played our games for a period of 5 days. After that, we conducted audio-recorded remote interviews with questions about the games and their overall perception of gestures.

Our results suggest that accessible games could be important in the process of learning gestures, as they offer a playful method of learning, particularly for less experienced users. This, in turn, would increase their autonomy and inclusion, as this process would become easier and more fun for them.
\end{abstract}

Keywords: Accessibility, Smartphone, Accessible Games, Gestures, Screen-Readers 



\section{Contents}

\begin{tabular}{ll} 
List of Figures & xv \\
\hline
\end{tabular}

List of Tables $\quad$ xvii

$\begin{array}{lll}1 & \text { Introduction } & 1\end{array}$

1.1 Motivation . . . . . . . . . . . . . . . . . . . . . . . 1

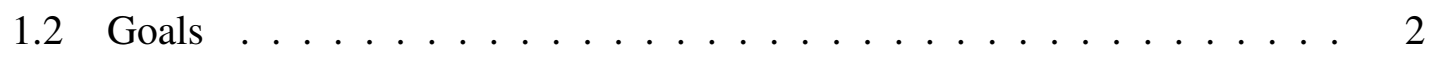

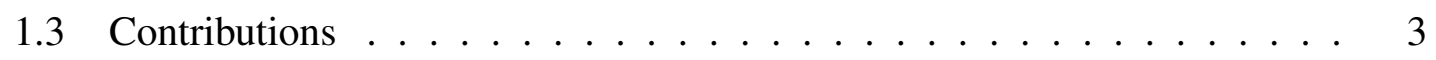

1.4 Document's Structure . . . . . . . . . . . . . . . . . 3

2 Related Work 5

2.1 Touchscreen Accessibility $\ldots \ldots \ldots$. . . . . . . . . . 5

2.1 .1 Gestures . . . . . . . . . . . . . . . . . . 6

2.1 .2 Text Entry . . . . . . . . . . . . . . . . . . . . . . . . . . . . . . . . 10

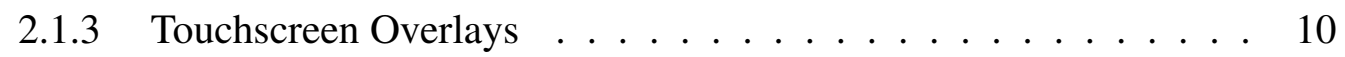

2.2 Accessible Gaming for Visually Impaired People . . . . . . . . . . . . . . . . . . . . . . . . . . . . . . . . . . . . . .

2.2 .1 Audio Games . . . . . . . . . . . . . . . . . . . . . . . . 12

2.3 Learning Through Gaming . . . . . . . . . . . . . . . . . . . 13

2.4 Discussion . . . . . . . . . . . . . . . . . . . . . 15

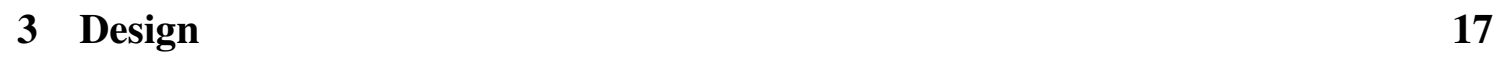

3.1 Design Motivations . . . . . . . . . . . . . . . . . . . . . . . . . . . . . . . . . 17

3.2 Use Case Scenarios . . . . . . . . . . . . . . . . . . . . . . . 18

3.3 Navigation . . . . . . . . . . . . . . . . . . . . . . . . . 19

3.4 Requirements . . . . . . . . . . . . . . . . . . . . . . . . . . . 19

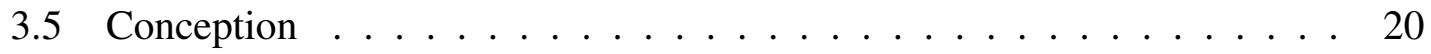

3.5 .1 Gesture Detection . . . . . . . . . . . . . . . . . . 21

3.6 Games For Gestures . . . . . . . . . . . . . . . . . . . 22

3.6 .1 Corda . . . . . . . . . . . . . . . . . . 22

3.6 .2 Foguete . . . . . . . . . . . . . . . 23

3.6 .3 Guarda Redes . . . . . . . . . . . . . . . . . . . . . 24

3.6 .4 Common Features . . . . . . . . . . . . . . . . . 25 


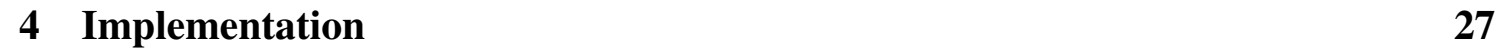

4.1 Overview . . . . . . . . . . . . . . . . . . . . . . . 27

4.2 Unity . . . . . . . . . . . . . . . . . . . . . . . . . 29

4.3 Common Design Aspects $\quad \ldots \ldots \ldots$

4.3 .1 Game States . . . . . . . . . . . . . . . . . . . . . . . 29

4.3 .2 Gesture Recognizer . . . . . . . . . . . . . . . . 30

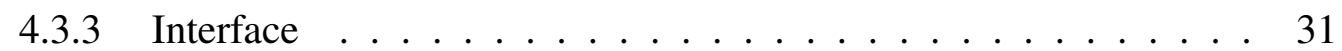

4.3 .4 Sounds . . . . . . . . . . . . . . . . . . 34

$4.4 \quad$ Gesture Implementation $\ldots \ldots \ldots$. . . . . . . . . . . . . . . . . . 35

4.5 Gesture Collection . . . . . . . . . . . . . . . . . . . . . 38

4.6 Tutorials $\ldots \ldots \ldots \ldots \ldots$

4.7 Foguete $\ldots \ldots \ldots \ldots \ldots$

4.8 Guarda Redes . . . . . . . . . . . . . . . . . . . . . . . . . 43

4.9 Corda $\ldots \ldots \ldots \ldots \ldots \ldots$

4.10 Database . . . . . . . . . . . . . . . . . 46

5 User Evaluation $\quad 51$

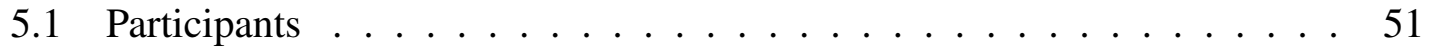

5.2 Procedure . . . . . . . . . . . . . . . . . . . 52

5.3 Data Analysis . . . . . . . . . . . . . . . . 53

5.4 Findings $\ldots \ldots \ldots \ldots \ldots \ldots \ldots$

5.4 .1 Exclusion from Playing _ . . . . . . . . . . . . . 55

5.4 .2 Gesture Learning and Perception . . . . . . . . . . . . . . 56

5.4 .3 Discovery Through Entertainment . . . . . . . . . . . . . . 57

5.4 .4 Gesture Practice and Discovery . . . . . . . . . . . . . . 58

5.5 Limitations $\ldots \ldots \ldots \ldots$. . . . . . . . . . . . . . . . 60

5.6 Discussion . . . . . . . . . . . . . . . . . . . 60

5.6 .1 Learning Process . . . . . . . . . . . . . . . . . 60

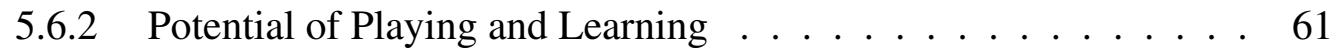

6 Conclusion $\quad 63$

6.1 Future Work . . . . . . . . . . . . . . . . . . . . . . . 64

\begin{tabular}{|ll}
\hline A Corda Tutorial Script & 67
\end{tabular}

\begin{tabular}{lll}
\hline B & Foguete Tutorial Script & 69
\end{tabular}

\begin{tabular}{|ll}
\hline C Guarda Redes Tutorial Script & 73 \\
\hline
\end{tabular}

\begin{tabular}{lll}
\hline D Interview Script & 77
\end{tabular} 
\begin{tabular}{lll}
\hline E & Demographics Questionnaire Script & 79
\end{tabular}

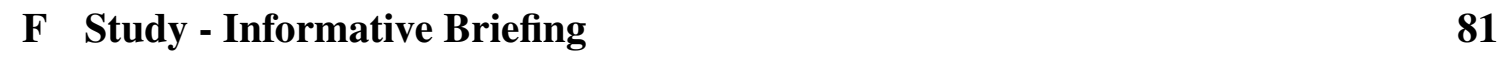

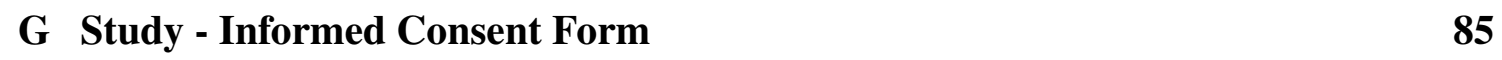

\begin{tabular}{|lr}
\hline H & Study - Codebook \\
\hline
\end{tabular}

\begin{tabular}{|ll}
\hline I $\quad$ Study - Themes Outline & 91
\end{tabular}

\begin{tabular}{ll}
\hline Bibliography & 99
\end{tabular} 



\section{List of Figures}

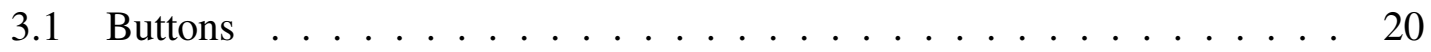

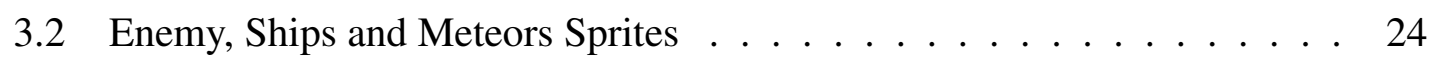

3.3 Goalkeepers Gloves and Football Field . . . . . . . . . . . . . . . . 24

4.1 Flow Diagram $\ldots \ldots \ldots \ldots \ldots$

4.2 Initial Screens - Foguete, Guarda Redes \& Corda . . . . . . . . . . 31

4.3 Guarda Redes - Toggle Buttons . . . . . . . . . . . . . . . . . . 32

4.4 Daily Games Notification System … . . . . . . . . . . . . . 33

4.5 Foguete - Screen Lanes . . . . . . . . . . . . . . . . . . . . . . 34

4.6 Amplitude of the angles measured $\ldots \ldots \ldots \ldots \ldots$

4.7 Player and Enemy Spaceship sprites $\ldots \ldots \ldots \ldots$. . . . . . . . . 42

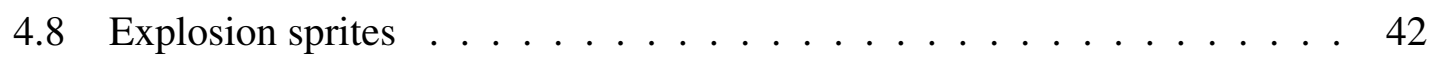

5.1 Gesture Performance - Total vs Correct (Corda) . . . . . . . . . . 53

5.2 Gesture Performance - Total Gestures vs Correct Gestures (Foguete) . . . 54

5.3 Gesture Performance - Total Gestures vs Correct Gestures (Guarda Redes) 54 



\section{List of Tables}

$2.1 \quad$ Google Talkback Gestures $\ldots \ldots \ldots$

4.1 User - Attributes and their description . . . . . . . . . . . . . . 47

4.2 Game Session - Attributes and their description . . . . . . . . . . . . . . 48

$4.3 \quad$ Detecao - Attributes and their description . . . . . . . . . . . . . 49

$5.1 \quad$ Demographic Information and Gaming Frequency of participants . . . . . 52

$5.2 \quad$ Play session time details. Playtime for each game rounded to seconds. . . 55

H.1 Study - Codebook . . . . . . . . . . . . . . . . . . . . . . 90

I.1 Study - Themes Outline . . . . . . . . . . . . . . . . . . . . . 91 



\section{Chapter 1}

\section{Introduction}

\subsection{Motivation}

Smartphones now have become the most common mobile devices and are part of one's life in many ways. These have gone from a tool that only makes calls and send messages to a multi-purpose tool that allows to communicate with colleagues and friends, to get any type of information and also for our entertainment. Not only that, smartphones changed the way people access information through services and how interactions with peers occur.

Smartphone's popularity and usability have created new opportunities in the development of ubiquitous assistive technologies. As a consequence, touch-based user interfaces have become one area of interest regarding mobile interaction as these can present significant accessibility barriers to blind or visually impaired users [26, 25, 39].

Mobile screen-readers, such as Google's TalkBack ${ }^{1}$ or iOs' VoiceOver ${ }^{2}$, are built-in screen readers that make smartphones generally accessible to blind people using commands or gestures through which the user can interact and use applications. While for some users these tools are mastered and allow them to use their smartphones freely, for other users with less experience interacting with these devices is still confusing and challenging to master, as it requires understanding the gestures or how navigation and textentry works, as these often require memorization of gestures and so, visually impaired people often adrift and have to undergo through a learning process in how to utilize these accessible tools [48, 51].

Throughout the years mobile accessible games have been developed and there are multiple examples of games available, either developed and posted on websites [3, 7, 53] or as the result of user-evaluated studies [30, 37, 56]. Video games are mainly designed for entertainment, which requires for them to be fun, captivating and these aspects put

\footnotetext{
${ }^{1}$ Google Talkback https://support.google.com/accessibility/android/topic/ 3529932 ?hl=pt\&ref_topic=9078845 (Last visited on October 5th, 2020)

${ }^{2}$ VoiceOver https://www.apple.com/accessibility/iphone/ (Last visited on October 5th, 2020)
} 
on major constraint on the way people interact with them. Audio Games share these attributes but are particularly appealing to blind and the visually impaired, as these not only are a solution to the fact that blind gamers might not play mainstream games but also serve as a meeting point for blind gamers as seen in AudioGamesNet ${ }^{3}$ website, where amateur developers, gamers and enthusiasts of audio games meet to discuss and share experiences.

Having said that, our objective is to understand if mobile accessible games can be used as a gesture discovery and practice method for people with visual impairments. By developing and providing interesting games that focus on how to perform a specific gesture, inexperienced and experienced users can understand on what occasions that gesture must be performed and how it should be performed correctly. Our major goal is to perform the task described previously, through a process of understanding the gestures involved in screen-reader technologies, understanding how these can be taught and a final user experience in which the results will be analysed.

\subsection{Goals}

Our major goal is to study whether mobile accessible games can be used as a gesture discovery and practice method for people with visual impairments. Through the development of interesting games that are focused on how to perform a specific gesture, inexperienced and experienced users can understand on what occasions that gesture must be performed and how it should be performed correctly.

Also, we aim to understand whether by playing our games participants felt any difference in their day to day use of smartphone and if their knowledge about gestures has improved. To achieve this, we will conduct audio recorded remote interviews in which we will ask participants what were their thoughts about the games and their general knowledge related to gestures, how to perform them, if they are using them successfully in their daily smartphone usage and whether they feel that after playing our games they started to use more gestures.

Another important aspect is to understand how we can develop our games in order to make their gameplay related to the gestures we are aiming to train. To do this, the development of the games in Android will be focused on how one or few specific gestures can be correctly applied and for that is important to understand how these gestures can be taught.

\footnotetext{
${ }^{3}$ AudioGamesNet https://audiogames.net/search-games/ (Last visited on September 1st, 2020)
} 


\subsection{Contributions}

Our main contributions with this dissertation are:

- A set of accessible games for smartphones, Corda 4 , Guarda Redes 5 and Foguete ${ }^{6}$, known as Games for Gestures, focused on the gestures Google Talkback has to offer. We designed and developed the games based on the research done on guidelines for the development of accessible games and these have resulted from adaptations of initial ideas.

- Our results suggest that accessible games can be used as a method of teaching and practising gestures on smartphones and proving that our games could serve that purpose.

\subsection{Document's Structure}

This document is organized as follows:

- Chapter 2 - Related Work. We provide an overview of how touchscreen accessibility increased over the years and how visually impaired users can interact with touchscreen interfaces, alongside with problems that might occur. We also introduce screen-readers and discuss touch-based gestures. We also delve into accessible games, particularly audio games, provide multiple examples of accessible mobile games and how they have served as an inspiration to the games we have developed. Finally, we take a closer look into how games can be used as a learning tool and the effects of learning through gaming, by providing examples of games used in this context with concrete results.

- Chapter 3 - Design. We present Games for Gestures. We start by explaining the design motivations, requirements and use case scenarios that served as motivation for their development. Then, we get into detail about the gesture detection our games implement and showcase the features our games offer, after explaining them and their purpose.

- Chapter 4 - Implementation. We explain the implementation of Games for Gestures. We start by providing an overview of the system and then explain in detail how our games aims to detect the same gestures Android's Gesture Detector detects. Then, we get into more detail about each game, their mechanics and development

\footnotetext{
${ }^{4}$ Corda https://play.google.com/store/apps/details?id=com.FCUL. Corda

${ }^{5}$ Guarda Redes https://play.google.com/store/apps/details?id=com.FCUL. GuardaRedes

${ }^{6}$ Foguete https://play.google.com/store/apps/details?id=com.FCUL. 
and what aspects are different between them. Finally, we also explain how they communicate with our databases, what information is stored and its relevance.

- Chapter 5 - User Evaluation. We conducted a user study with 6 visually impaired participants with different levels of smartphone expertise which lasted for 5 days. Each participant played our games for that period. After it, we have conducted audio recorded remote interviews in which we would ask participants their thoughts on our games and whether they have reflected any change in their smartphone usage. We present the results.

- Chapter 6 - Conclusion. Our final thoughts on the work and prospects for future work. 


\section{Chapter 2}

\section{Related Work}

We identified three main areas of related work: touchscreen accessibility, accessible gaming and learning through gaming. In the first area we will discuss the challenges that touchscreen interfaces offer, introduce screen-readers and discuss touch-based gestures. In the second area we will describe Audio Games, what they are and how they can be implemented and the benefits of increasing accessibility in games. In the third area we will discuss how video and audio games could be used as an educational tool with various examples of technologies developed and a series of guidelines for the development of accessible educational games.

\subsection{Touchscreen Accessibility}

Touchscreen devices have become the standard of input and interaction for mobile devices and blind people have been incorporating them into their lives. Touchscreen interfaces offer the advantage of flexibility and control as they can display different interfaces on the same surface, such as a scrollable list, a QWERTY keyboard or a telephone keypad. In addition, they allow users to manipulate items directly on the screen.

Touchscreen interfaces support interaction through multiple techniques such as tapping, selecting, swiping and more complex gestures such as flicking, rotating and pinching [62] as these are supported by multi-touch interfaces.

One of the earliest research in the area [45] compares three touchscreen interaction techniques which years later have been adopted for touchscreens: land-on, which consists in activating what was first touched on the screen; first-contact, which works has land-on except that if nothing is immediately touched, the user can slide the finger to the desired target and whatever target was touched first is activated and take-off, in which there would is a cursor in the shape of a plus sign above the user's finger and the user moves the cursor until it hovered over the desired target.

These interaction techniques are highly used in commercial touchscreens of various sizes. For example, Android mainly uses a land-on technique: if the user misses the target 
and tries to move the finger to the target, other actions may occur. Android also uses the take-off strategy in its QWERTY keyboard, as it allows the user to correct an error by moving the finger to the desired letter and lifting it off [20].

Android and iOS, the most popular mobile operating systems, have developed built-in screen readers that make smartphones more accessible to blind users through the use of gestures. Google Talkback ${ }^{1}$ is the screen reader developed by Android and VoiceOver ${ }^{2}$ is the screen reader developed by iOS. These provide different methods of navigation for visually impaired users with different levels of expertise in using their smartphone and are a tool that aims to increase the accessibility of touchscreen interfaces.

Although screen reading software has improved the accessibility of touchscreen interfaces, they have limitations. First, they typically only provide audio feedback and cannot provide tactile feedback which is also useful to blind people. Second, they are adapted to smartphones' touchscreens and other types of touchscreens may present additional interaction challenges [27]. Third, there is often a conflict between the screen reader and the information presented by the application, often resulting in the loss of information for the user [42, 8]. In addition, the localization of that information could be better provided, through references to the keys or to absolute locations, for instance, the edges of the phone [51].

Smartphones are perceived as very useful and physically easy to use but also offer challenges or barriers such as the cost, lack of configurable assistive settings and difficulty of usage under certain circumstances [60, 26]. Smartphone's accessibility disadvantages cause some blind people to face challenges and possibly leads to a learning or an adoption process of their smartphones in their day to day interactions [48, 26]. Also, inexperienced users show concerns with the lack of support and set of inconsistencies about how the device's services and accessibility features behave.

Despite these challenges, visually impaired users see their smartphones as an important part of their daily activities to improve their independence and autonomy and as source of entertainment and show commitment and willingness to continue exploring and improving their ability [51].

\subsubsection{Gestures}

Mobile smartphones with touchscreens have become more popular amongst blind and visually impaired people. The development of screen-readers has made smartphones more accessible and visually impaired people feel they could become part of their lives through a set of gestures.

\footnotetext{
${ }^{1}$ Google Talkback https://support.google.com/accessibility/android/topic/ 3529932 ?hl=pt\&ref_topic=9078845 (Last visited on October 5th, 2020)

${ }^{2}$ VoiceOver https://www.apple.com/accessibility/iphone/ (Last visited on October 5th, 2020)
} 
However, this feeling is not shared by the entire community as some cannot discard their feature phones with keys. As learning how to use a smartphone is a difficult process, many overcome the challenges and become expert users while others just stay at the novice level. Also, many users tend to not change from their feature phones to smartphones as there are still options available on the market and as these prove to be more useful for them in certain situations [51].

A lot of research has been conducted on how the gestures could be performed and the preference of gestures, considering multiple finger gestures, strokes, taps and their length and the use of sonification techniques to teach and correct gesture performance. [5, 47] explore how gestures could be improved to make touch based interactions more accessible and usable to visually impaired users and gestures with multiple fingers, strokes or longer gestures were identified as the most difficult.

Kane, Wobbrock, and Ladner [29] performed two studies two studies on preference and performance of touch gestures compared to sighted people. The first consisted in asking participants to invent gestures for a given set of tasks, allowing them to conclude that blind have preference for gestures that use screen corners, edges, multi-touch and gestures that involve tapping virtual keys on a keyboard. The second was to determine whether there were significant differences between the two groups of participants. Significant differences were found in the speed, size and shape of gestures performed.

Based on those studies, Kane et al. proposed a series of guidelines for usable touchbased gesture interaction. These guidelines suggest not using print symbols such as letters, numbers or punctuation, to favor screen landmarks, reduce location accuracy demand through better targeting methods [39], limit time-based gestures to reduce errors and use familiar layouts and consistent placement when possible.

Anthony et al. [1] also suggest alternative support for multi-touch interaction, for users who might not be able to perform multi-finger gestures and constant touch habituation, in which long duration touches that do not change or move would be ignored by the system.

A study performed by Sandness et al. [55] explored the use of one-finger touch-based directional gestures on self-service devices. The user would be given a set of options and would select an option by performing a simple gesture in any part of the screen in the direction of the desired option. Even though this study was performed in a touch-based kiosk, it was well received by people with and without visual impairments.

Google Talkback is a built-in an screen-reader included on Android devices that makes smartphones generally accessible to blind and visually impaired people through gestures with which the user can interact and use applications. It provides auditory feedback so users can take advantage of the device without looking to the screen.

Talkback offers two methods of navigation: Explore by Touch and Swipe to Explore. Explore by Touch consists in slowly dragging one finger around the screen while hearing 
the icons, buttons and other items as the finger is over them. Swipe to Explore explores the screen items one at a time and to explore the user has to swipe left or right to move through the items in sequence.

Talkback focuses on one item by surrounding with a green square rectangle, the focus. When an item is focused, to activate it the user has to perform a double-tap. This method of selecting an item is present in both methods of navigation.

Talkback offers a set of simple gestures, mainly used to navigate using Swipe To Explore. These only require one finger to be performed. Also, Talkback offers a set of gestures for operations such as scrolling or zoom. Finally, Talkback offers a set of advanced gestures to navigate with one finger, two-part swipes at a right angle, intended for experienced users and a faster navigation.

When compared to VoiceOver, both use tap and double tap to select and activate items, as well as swipe left or right to navigate within the interface. Both also offer a similar interface exploration, in which the user can touch or drag a finger over the screen to hear the items presented in the interface. However, VoiceOver offers more than twenty gestures and the number of fingers to perform them varies from one to four. Additionally, taps can be single, double or triple. It also offers gestures which have different results in the context of different applications.

We can divide Talkback gestures into three types: basic gestures, back-and-forth gestures and angle gestures. Table 2.1 lists all Talkback gestures. The table is divided by the type of the gesture, the gesture, the action performed and the number of fingers required to perform the gesture. All gestures listed below are assignable to new actions. 


\begin{tabular}{|c|c|c|c|}
\hline Type of Gesture & Gesture & Action Performed & F. Req. \\
\hline \multirow{11}{*}{ Basic } & Swipe Right & Moves to the next item & 1 \\
\hline & Swipe Left & Moves to the previous item & 1 \\
\hline & Swipe Left or Right & Change pages and screens & 2 \\
\hline & Swipe Up or Down & Cycles through the navigation settings & 1 \\
\hline & Swipe Up or Down & Scrolls through lists and pages & 2 \\
\hline & Double-tap & Selects focused item & 1 \\
\hline & Drag one finger & $\begin{array}{c}\text { Explore screen and hear aloud } \\
\text { what is being touched }\end{array}$ & 1 \\
\hline & Drag on input text field & Move character by character & 1 \\
\hline & Press and hold & Long press to open additional menus & 1 \\
\hline & Double-tap anywhere & Activate the last item touched & 1 \\
\hline & Press and hold & [Lock Screen] Turn on Talkback & 2 \\
\hline \multirow{4}{*}{ Back-and-forth } & Up then Down & Moves to the first item & 1 \\
\hline & Down then Up & Moves to the last item & 1 \\
\hline & Right then Left & Scrolls forward or moves slider up & 1 \\
\hline & Left then Right & Scrolls backwards or moves slider down & 1 \\
\hline \multirow{7}{*}{ Angle } & Up then Left & Goes to the Home screen & 1 \\
\hline & Down then Left & Goes to the previous screen & 1 \\
\hline & Left then Up & Provides an overview & 1 \\
\hline & Right then Down & Opens the Notifications Tray & 1 \\
\hline & Left then Down & Allows for screen search & 1 \\
\hline & Up then Right & Opens local context menu & 1 \\
\hline & Down then Right & Opens global context menu & 1 \\
\hline
\end{tabular}




\subsubsection{Text Entry}

Today's touchscreen devices present challenges related with text-entry, by the fact that interfaces display all the letters on the screen and many letters carry multiple options, such as to insert a specific character or number, with gesture accuracy and even with the efficiency of the interfaces [51, 8].

Studies such as [40, 49, 39, 21] illustrate some of the needs for improvements of touchscreen text-entry methods as well as coping strategies, which include memorization of the device's functions, customization of their devices or even the use of multiple devices at the same time to overcome the limitations of one of those devices [26].

No-Look Notes [4] and NavTouch [21] are examples of text-entry systems for touchscreens developed to address these situations, that offer an easier access to the alphabet through a small number of gestures. BrailleTouch [9] serves as another example, despite being in the context of Braille literacy.

Text-entry methods are an important aspect of screen-readers even though they are not directly relevant to the work that will be performed, but previous examples are mentioned as they are about touch-based gesture interaction.

\subsubsection{Touchscreen Overlays}

Tactile overlays, alongside vibrations or friction, are often used for aid and exploration on a large touchscreen and offer haptic feedback as a means to accurately inform and help the user. These consist in interaction techniques that improve touchscreen usability while preserving an application's original spatial layout and are implemented as semi-transparent windows that are placed above standard applications [27, 28]. When activated, it gathers information about the location and context of all on-screen targets and provides access to them through a combination of speech and audio feedback, alternative gesture input and additional user interface controls. Furthermore, they do not require any alterations to the underlying touchscreen hardware [27].

Access Overlays [27] and Personalizable Static Overlays [50] offer a set of softwarebased overlays intended to improve the accessibility of large touchscreen interfaces, the first through three techniques that help the user search and identify targets on-screen and the second through a virtual overlay that superimposes all other interfaces on the screen.

\subsection{Accessible Gaming for Visually Impaired People}

Video games throughout the years have spread wide across multiple platforms and devices, like computers, mobile phones and others. These are heavily based on visual aspects such as the interaction, scenery and scenario and colors, shapes, text and visual objects are the main aspects communicated to the gamers and are designed for entertain- 
ment, which requires them to be fun. Much of this growth revolves around the use and development of powerful graphical engines that can support three-dimensional worlds and visually immersive games.

However, video games often are not fully accessible. People with visual impairments may find it impossible to play games which rely on visual feedback. On one hand, increasing the accessibility of games could bring benefits such as the inclusion in social and gaming communities as well as physical and health benefits [12] for gamers. On the other hand, developers struggle as the cost of implementing accessibility features is not worth the return and there is not a wide-enough audience to make accessibility development worthwhile [64].

Porter and Kientz [44] analysed the current state of accessibility in games, to identify and understand issues and barriers. Surveyed gamers expressed that some games do not recognize input from assistive devices and software and needed to ask for external help, which diminished the gaming experience and brought them feelings of reluctance. Surveyed developers explained the lack of accessibility in gaming is derived from the fact that developers are mostly able-bodied individuals, thus making certain impairments a concept not considered important in game development.

To address these issues, multiple studies have been conducted to identify and suggest guidelines for the development and improvement of accessible games [43, 36]. Garber [12] suggests the use of subtitles, adjusting hues for colour-blind players and allow the customization of the text size, characters and game sensitivity. Porter and Kientz [44] suggest testing games with people with disabilities, to better identify problems of the current games. Barlet and Spohn [22] offer accessibility guidelines directed to smartphones such as adding a buffer against accidentally touching the same stop and having a 'hit box' delineating the touchable area of the screen. Leporini and Hersh [32] suggest multimodal feedback and options to turn them off, as well as compatibility with assistive technologies, enabling users to access games in the most appropriate ways.

To further increase accessibility, another point of view could be by making games accessible to everyone, visually impaired and not visually impaired. Universally Accessible Games [19] are games that can be concurrently played by people with different abilities and preferences, including people with disabilities. Instead of targeting one specific audience, they target various disability groups simultaneously, allowing the use of assistive devices or altering the user interface to suit to each individual's needs.

David et al. [17] shares multiple gaming experiences of people with visual impairments and comes to the conclusion that people with visual impairments play diverse games but lack the opportunity and experience of playing with players who have different visual abilities. This limitation is described as a lack of intersection in gaming opportunities and it reflects in the habits and interests of people with different visual abilities. 


\subsubsection{Audio Games}

Audio games are games on which the user interface and game events use primarily sounds instead of graphics to convey information to the player. These can provide an accessible gaming experience to visually impaired players [13]. Their development typically falls within two categories: either they were the result of an adaptation of a game or were developed specifically for visually impaired people.

Through the use of sound, players can have more possibilities for gameplay that do not exist with visuals alone, which allows for games far more accessible to people with all levels of sight.

Audio games can be played and enjoyed by sighted people and by people with visual impairments alike. They are particularly appealing to blind people and have a strong fan base that develops, plays, enjoys and discusses these games on websites such as AudioGameHub 3 and AudioGamesNet

Rovithis et al. [52] provide an overview of the existing techniques that manipulate sound and suggest three categories, each one representing a different function of the overall gaming experience: sounds that replace a visual user-interface and allow for the player's navigation through the game options-menu; sounds that are used as feedback on the player actions and sound stimuli that express the game's plot, mechanics and meaning.

There are multiple games that use different sound strategies to become accessible to blind gamers: Mach 1 Car Racing [23] is a remake of the classic racing game Pole Position. To indicate which direction to turn, the game provides audio cues such as the echo of the player's engine. In addition, the game uses self-voicing with an adjustable rate of speech. Players control their car using the arrow keys. Similar games are Blindfold Racer [34] developed for iOS and RAD [56].

Shades of Doom [16], AudioQuake [2] and Terraformers [61] are first-person shooter games which use different accessibility strategies. Shades of Doom uses audio cues to help find the way through the levels. A navigation tool provides synthetic speech about the player's surrounding. AudioQuake uses structured sounds to alert the play for an object or event. Terraformers uses a sound compass where different tones are used to indicate the direction the player is pointing. It also offers a sound radar that can be used to identify what is in front of the player. With that radar, it is possible for the player to tell how far objects are.

Finger Dance [37] and Blind Hero [63] are modifications of Dance Dance Revolution and of Guitar Hero, respectively. The first replaces the original music with audio cues that indicate which keys the player music touch, while the second uses a glove that provides

\footnotetext{
${ }^{3}$ AudioGameHub http://www. audiogamehub.com/games/ (Last visited on September 1st, 2020)

${ }^{4}$ AudioGamesNet https://audiogames.net/search-games/ (Last visited on September 1st, 2020)
} 
tactile feedback on which inputs the player must provide, preserving the original music.

VBGhost [38] is a game designed for visually impaired players as an adaptation of "Ghost", a word game in which easy player adds a letter to an existing word fragment, without completing a word or writing an invalid fragment. VBGhost achieves accessibility by offering a high contrast menu, reading options and word fragments aloud on touch.

UA-Chess and Access Invaders [18] are games in which two gamers with different (dis)abilities can play using a variety of alternative input or output modalities and techniques in any combination. Both support various input methods, are highly customizable, offer output through visual or auditory displays, use profiles to adapt the game to each person and support non-visual gameplay. Access Invaders, however, struggled as players with different abilities perceived the game differently.

AudiOdissey [15] and ShadowRine [11] are also accessible games designed for sighted and visually impaired gamers to play together. AudiOdissey features multiple input controls, fully accessible menus and play levels allowing all individuals to share a common gaming experience. ShadowRine uses a screen reader to provide audio information on the cursor location and keyboard operations to design 2D fields.

\subsection{Learning Through Gaming}

Gestural interaction has become a primary means of touchscreen input across a range of devices, from smartphones to tablets and even personal computers. To interact accurately, touchscreen gestures must be performed according to a certain convention that has to be learned [41]. For example, user interfaces that support directional swipe gestures may identify the gesture based on its location, its speed, its length and its angular direction and all these characteristics must fall within expected constraints to be properly classified.

Learning how to perform gestures correctly may be especially difficult for users with visual impairments. While sighted users may learn to perform gestures through observation of other users, video or in-application tutorials or visual feedback provided from the applications, methods which effectively teach how to perform gestures more accurately, that observation and those methods are not accessible and learning gestures on a screen can be challenging [41].

Several projects have used sonification to address this problems, mainly to teach nonsighted users shapes. GUESS [24] allowed blind users to explore simple shapes using a stylus and a tablet with sonification feedback, combining pitch and stereo. Timbremap [58] also combined pitch and stereo with spearcons to guide blind users in exploration of a touchscreen map. However, these systems were primarily optimized for slow exploration of a shape, rather than gestural aspects such as rotation and speed of a gesture.

Based on the research explained previously, Oh, Findlater and Kane [41] proposed 
two techniques to teach gestures based on sound: one is corrective verbal feedback with text-to-speech and automatic analysis of the user's drawn gestures and the other is gesture sonification, to generate sound based on finger touches, creating an audio representation of the gesture. Their findings suggest that sonification and corrective verbal feedback can be useful for helping blind users to replicate a variety of gestures, such as taps, swipes, shapes and multistrokes and multitouch gestures.

Video games are a technology that specialises in engaging and motivating users to spend time on a task or a set of tasks. And they are highly successful in doing that. One could argue all video games are educational as they train the key skills for the player to gain success within the game. And lately there has recently been a great deal of interest in the potential of games to function as innovative educational tools and in understanding the motivational qualities of mobile and computer games to create educational tools.

Video games can be a successful educational tool, as they are engaging, motivate users to spend time on a task an on perfecting it and have the potential to improve learner motivation and consequently, learning outcomes. Through repetition and a captivating gameplay, a user can become better and achieve better results at a game he is playing and enjoy that process.

While it seems apparent that games have the potential to function as a powerful learning tool there is little evidence that they produce reliable, valid and long-lasting educational outcomes and that they are better than the traditional educational tools. However, this does not mean that games have not produced positive educational outcomes.

Lee et al. [31] through Skills Arena investigated whether their educational mathematical drill game could be integrated into a class room. Their findings were that students completed 3 times as many maths problems over 19 days using a computer game than they normally did using just worksheets. McLean et al. [35] performed similar work and found positive results for games in comparison to other teaching methods, across a range of games that taught geology and biology.

Targett and Fernström [59] investigate the entertainment of audio games and if these could be used for skills acquisition or in therapeutic applications. To this, they developed two games: Os \& Xs, a variation of the classic game Tic Tac Toe and Mastermind. User testing confirmed these game were particularly interesting for the blind community and showed that audio games could assist in increasing both memory and ability to concentrate.

Linehan et al. [33] provide a practical framework for designing engaging game mechanics in educational games based on empirically validated teaching methods developed by behavioural psychologists. Their suggestions are based on the goals and rewards of the game, as goals should be achievable and divided into smaller goals if not achieved and rewards should be offered according to the player's rate of completion of those rewards and their pace and skill through the game. 


\subsection{Discussion}

We explored three main areas: touchscreen accessibility, accessible gaming and learning through gaming. We found that despite current attempts towards touchscreen accessibility, there are still multiple issues.

Touchscreen accessibility continues to be a problem despite multiple attempts to increase it, one of them being screen-readers. These have proven to be a successful tool, although still have limitations. We analyse Google Talkback and look into the gestures the screen-reader offers and the overall preference for gestures in touchscreens, concluding that gestures involving multiple fingers, strokes or longer gestures were the hardest to perform.

We also looked at accessible games, the benefits of improving accessibility in video games and found out that developers struggle at the cost of implementing accessibility features and do not consider their development to be worthwhile, leading to a concept deemed not important in game development. To address this, we have identified guidelines for creating games more accessible, which will be taken into consideration.

In addition, we looked into audio games as these use primarily sounds instead of graphics to convey information to the player and can provide an accessible gaming experience to people with all levels of sight through the use of different sound strategies. We provide with multiple examples of audio games that have served as examples for the development of our games.

We explored educational games and how these can be used as a tool to effectively make players learning through playing them. To achieve this, games must be engaging and motivate users to spend time on a task and on perfecting it. To show this, we present examples of educational games for sighted users and for blind users and show how their results can prove that games are a valuable learning tool.

We also investigate guidelines for the development of engaging game mechanics for educational games and found out that implementing an in-game reward system with achievable goals according to the player's rate of completion of the tasks and skill could be a manner of engaging and motivating users to play and spend time on the game. 


\section{Chapter 3}

\section{Design}

The previous chapter review the current state of art in touchscreen accessibility, their shortcomings and in how games have the potential of being used as a learning tool. We have discussed audio games, how they are perceived by the community and the role they can have in both being a method of enjoyment and a method of practice of gestures.

In this chapter we will describe the use case scenarios that have inspired the creation of our games. We will also present Games for Gestures, a set of games we have developed to explore and practise the gestures offered by Google Talkback. We will enter into more detail about their requirements, conception and the process of how we aim to correctly detect the same gestures that Android detects.

\subsection{Design Motivations}

The research done previously allowed us to understand the challenges of interacting with a touchscreen device for visually impaired people. Also, we took a closer look into how audio games can be a learning tool through multiple examples of new games or adaptations of existing games that proved to be successful in teaching concepts, either to one person or to a set of people playing together.

These examples have allowed us to produce a set of ideas that resulted in successful implementations of the games. Taking into consideration the research done previously, we modified those ideas and made them be more related with the set of gestures we aim to teach with our games.

To better understand the challenges experienced and how visually impaired individuals interact with their smartphones, we have embedded in the community by participating in monthly regular sessions in a local centre, where we would mainly provide smartphone support. These sessions allowed us to observe their interactions in detail, how they navigate on their smartphones, how accurate that navigation is and what challenges they experience. Not only that, it also allowed us to understand how these challenges are overcome. 


\subsection{Use Case Scenarios}

Carlos and Maria are two fictional personas we have created to detail two use case scenarios that served as the basis for the development of our games.

Carlos recently bought a smartphone and only knows how to navigate with Explore by Touch.

Carlos wants to listen a podcast.

Carlos is in his home and wants to listen to his favourite podcast, about remote islands. Carlos wants to listen to the most recent episode but does not know if there are any recent podcasts, as on the screen are only displayed the first two and Carlos does not know how to navigate to more episodes. As Carlos only knows how to Explore by Touch and has not learned any other navigation mechanisms, he is unable to reach the episode he wishes. Carlos has a game on his smartphone that has taught him a set of gestures that allowed him to play the game. These gestures correspond to the set of gestures used to navigate using Swipe To Explore. Carlos has discovered not only these gestures through the game but also can practise them and can become better at performing them by playing. Carlos then selects the first podcast of the series and performs a swipe right, which reads aloud the title of the next podcast. After hearing it, Carlos realizes he has already heard that podcast and performs another swipe right to listen to the next title. The screen now is displaying a new podcast which Carlos was not able to hear. Carlos then selects it and listens to it. Carlos never faced this problem again.

Maria has been using a smartphone for more than 6 months, knows how to navigate with Explore by Touch and Swipe To Explore but wants to search for a contact faster using advanced gestures.

\section{Maria wants to call to her friend Rosa.}

Maria wants to call her friend Rosa and ask her how she has been. Maria first opens the application Contacts, selects the first contact and listens to it. However, Maria is only displayed few contacts, none of which is Rosa's and wants to reach her contact faster. Rosa has recommended Maria to install a game that teaches her about a set of gestures to play the game. This game teaches a set of gestures used to navigate using advanced gestures, such as swipe back-and-forth left then right and right then left. Maria has discovered that she can practise those gestures by playing the game and that she could use them to navigate faster in her smartphone, in this case, to search for a contact faster. Maria then selects the first contact of her list and listens to it. Then, Maria performs a right swipe to advance to the next contact. After a while, Maria reaches her friend Rosa, selects 
her contact and calls her. To navigate even faster, Maria now selects her first contact and performs a right then left swipe, moving the slider of her contacts page lower, closer to her contact Rosa. Now Maria searches for any contact much faster than she used to.

\subsection{Navigation}

Google Talkback offers two means of exploration: Explore by Touch and Swipe To Explore. Explore by Touch consists in slowly dragging one finger around the screen while Google Talkback announces the icons, buttons and other items as the finger is over them. In addition, Talkback focuses on the item by surrounding it with typically a green square or rectangle, the focus. When an item or button is focused, to activate it the user has to perform a double-tap.

Swipe To Explore works differently. To explore the screen one item at a time, the user has to swipe left or right to move through the items in sequence. When an item is focused, Talkback provides with a hint after a short delay about the actions that can be perform on that object. Further, this method of exploration allows the user to select what type of navigation settings he wants to use: navigation by headings, navigation by links, navigation by checkboxes or to explore every element in a page in a logical order.

We intended our games offer at least with one of these types of navigation. This allows us to ask our participants to turn off Google Talkback while playing with our games, as complications arise from playing our games while Talkback is turned on.

To navigate in our games using Explore by Touch, the user has to drag one finger on the screen to hear the options available to him. If the user wants to enter one of those options, while it is focused they have to perform a double-tap on the screen.

\subsection{Requirements}

The research performed in terms of accessibility guidelines from the various examples we have explained previously allowed for us to identify the following set of requirements before the development of our games:

- Simple games with short sessions: our games have to be simple and played in short sessions and this their gameplay has to reflect this.

- Based on the gesture's movement: a gesture has to be related to one movement and the movement performed by the gesture needs to be associated with the game's mechanics.

- Same gestures as Talkback: the gestures offered by our games have to be the same gestures Google Talkback offers and can only recognize those gestures.

- Ability to learn, practise and understand the gestures: our games need to teach the user how to perform the gestures accurately, to practise and explain them in a 
simple manner.

- Understand the function of the gesture: our games need to explain how the gestures performed are related to the gestures used by Google Talkback.

- Accessible like screen-readers: our games have to be accessible in the same way the users are used to screen-readers, by providing Explore by Touch.

In addition, we want navigation on our games to be as simple as possible. As such, Buttons are displayed horizontally and multiple buttons on a page are presented on top of another, resembling the organization of the android settings menus, displaying multiple options. This organization allows users to navigate through our games using Explore by Touch the same way they would navigate through their smartphones.

To complement what we have explained previously, the height of the buttons is higher than usual so they are easier to locate and distance between two buttons is small, once again contributing for Explore by touch to be easier. Finally, buttons are displayed starting from the bottom of the screen. Figure 3.1 shows the organization of one of the pages with multiple buttons.

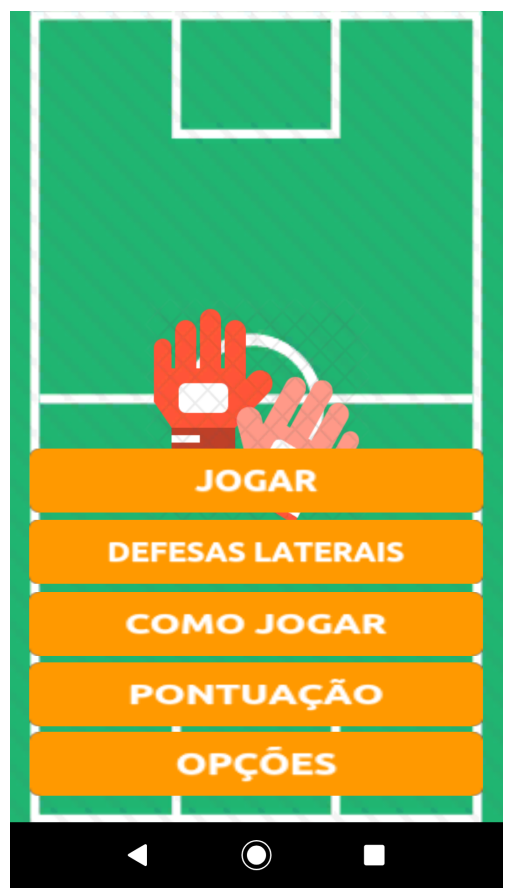

Figure 3.1: Buttons

\subsection{Conception}

In this section we get into more detail about how we aim to correctly detect the same gestures that are detected on Android. We will delve into Android's Gesture Detector, how it works and how we plan to implement our gesture detector to be as similar to Android's as possible. 


\subsubsection{Gesture Detection}

A key aspect of our work is that the gestures identified and used in each game are identical to the gestures recognized by Android and by Google Talkback. So, we had to delve into Android's gesture detection, to understand how it works and how we can implement our own gesture detector.

Android's gesture detection is comprised of two phases: data gathering about touch events and interpretation of the data, to see which criteria it meets. When the users touches the screen, the View that receives those events triggers the callback onTouchEvent(), responsible for handling touch screen motion events. A Motion Even $1^{1}$ describes movements in terms of an action code and a set of axis values. The action code specifies the state change that occurred such as a pointer going down or up. The axis values describe the position and other movement properties.

Motion Events are typically composed by this set of pointers:

- MotionEvent.ACTION_DOWN: triggered when the user first touches the screen;

- MotionEvent.ACTION_MOVE: triggered while the user is moving its finger through the screen;

- MotionEvent.ACTION_UP: triggered when the user lifts its finger from the screen;

- MotionEvent.ACTION_CANCEL: triggered when this action is canceled;

- MotionEvent.ACTION_OUTSIDE: triggered when the movement occurs outside of the boundaries.

The Gesture Detector ${ }^{2}$ defines a set of listeners used to notify when a gesture occurs and it uses Motion Events carrying the information with the users' touch. It consists of two interfaces: OnGestureListener is used to notify when a gesture occurs and OnDoubleTapListener is used to notify when a double-tap or a single-tap event occurs.

OnGestureListener also makes use of a set of threshold values that define the characteristics of a swipe, a tap, a double-tap or a long-press. Those values are defined in the View Configuration ${ }^{3}$ In there, to correctly say that a user has performed a swipe, the Gesture Detector accesses two thresholds: the minimum and maximum value of velocity, which is set to 50 and 8000 dips per second and the minimum distance for a scroll, 8 dips.

\footnotetext{
${ }^{1}$ Motion Eventhttps://developer.android.com/reference/android/view/ MotionEvent (Last visited on October 5th, 2020)

${ }^{2}$ Gesture Detector https://android.googlesource.com/platform/frameworks/ base/+/56a2301/core/java/android/view/GestureDetector.java (Last visited on October 5th, 2020)

${ }^{3}$ View Configuration https://android.googlesource.com/platform/frameworks/ base/+/master/core/java/android/view/ViewConfiguration.java (Last visited on October 5th, 2020)
} 
To correctly identify a double-tap, the Gesture Detector accesses two thresholds: the maximum duration between the taps, 300 milliseconds, and the maximum distance between the taps to be considered a double-tap, 100 dips.

When a swipe is performed, the Gesture Detector will analyse the given motion event and trigger the appropriate callbacks: to begin with, it will gather the information about the moment when the user first touches the screen; then, it will check whether the touch is part of a double-tap touch, a single-tap touch or a long-press touch - if it is, the next steps do not occur; the next step is to measure the distance of the performed swipe and check whether it exceeds the threshold defined for the distance of a swipe and finally, when the user lifts its finger, it will calculate its velocity and check whether it is faster then the defined threshold. If all conditions are met, the Gesture Detector confirms the user performed a swipe.

When a double-tap is performed, the Gesture Detector performs a similar operation to the one described previously: to begin with, it will receive the information related to the user's first touch; after that, it will check whether the touch is part of a single-tap touch, a double-tap touch or a long-press touch; if the next user input is another touch, the Gesture Detector will check whether we are in the presence of a double-tap. If the characteristics of this double-tap are lower than the thresholds, than it has correctly identified a doubletap and the application's context will interpret that gesture.

\subsection{Games For Gestures}

Games for Gestures are the set of accessible games we have developed in the context of this thesis. These games focus on the gestures Google Talkback has to offer, listed in Gestures and allow to understand the expected result of a gesture outside of the game. Taking into consideration the number of gestures offered, we have decided to create three games, as we felt we could incorporate more gestures with more than one game.

Corda focuses on teaching how to navigate the smartphone through Explore by Touch. Foguete was developed to train the directional swipes left and right and is focused on teaching Swipe to Explore. Guarda Redes is the most complex game, it was developed for more experienced users and is focused on the more advanced gestures, such as back-andforth gestures or L-shaped gestures.

\subsubsection{Corda}

Corda is the first game we developed. Here, the player is playing jump the rope in the playground. Players will hear a sound cue of a rope hitting the ground. When that sound occurs, it means the rope has hit the ground and the player has to jump. Otherwise, the player will trip on the rope. 
The goal of Corda is to teach how to correctly perform a double-tap and is focused on Explore by Touch, as this mode of navigation includes selecting an option and performing a double-tap to enter or activate it.

The player's goal in Corda is to listen to when the rope hits the ground and then jump. The longer the user lasts, the faster the rope sound cue is be played and the time the player has to perform the gesture to jump correctly decreases.

A tap on the screen means the user is lifting one of its legs to jump. To jump correctly, the player is required to perform a double-tap. If they do not jump or do not jump correctly, they will trip on the rope and lose. When the player performs a double-tap on the screen, our game will analyse the difference in milliseconds between the touches that compose that double-tap, to determine whether is was a perfectly executed. Each of these scenarios are successful in jumping, but a perfect double-tap will give more points to the player.

Corda was created as we intended to analyse the double-tap gesture, which is not present in any of the other games. Considering the other two games, we could not find a way to incorporate the double-tap into their gameplay in a meaningful way without affecting it in a negative manner. Also, the introduction of a third game allowed us to not increase the number of gestures practise in any of the games, specially Guarda Redes.

\subsubsection{Foguete}

Foguete is based on the classical Asteroids game. Here, the player's spaceship is floating through space and it has to dodge from enemies and catch bonus points. Enemies consist of enemy spaceships and asteroids. The game has a background music resembling old arcade games, further increasing the player's immersion while playing.

We have divided the screen in three identical vertical areas: left, center and right. The player will hear a sound cue, signaling a new enemy is coming from his left or right adjacent area. The goal of the game is for players to learn and practise Swipe to Explore. So, players use swipes left and right to dodge. The player's goal is to score the most amount of points.

If the player hits an enemy then loses one life, ending the game when all three are lost. If the player hits bonus points, then will receive extra points. If the player successfully dodges an enemy, an audio cue will be played signaling the enemy has passed the player's ship position.

Foguete also has available a menu which explains all sounds present in the game. This menu allows the players to see and hear a small explanation about the sound used that they are hearing. Finally, in the main page the player is able to check their highest score. 


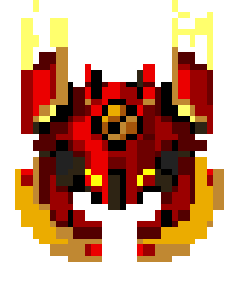

(a) Enemy Sprite

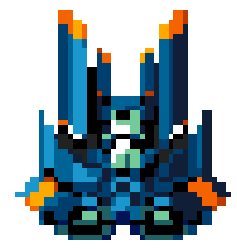

(b) Player's ship Sprite

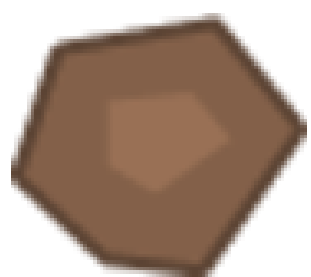

(c) Brown Meteor Sprite

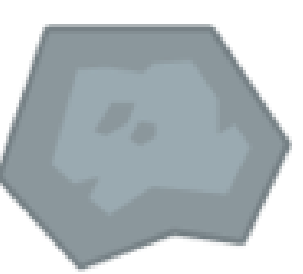

(d) Grey Meteor Sprite

Figure 3.2: Enemy, Ships and Meteors Sprites

\subsubsection{Guarda Redes}

Guarda Redes was developed for more experienced users and has the purpose of teaching the advanced gestures Google Talkback has to offer, namely L-shaped and Back-andForth gestures, gestures that Foguete was not able to provide. Also, the gameplay offered by Guarda Redes proved to be a meaningful way to implement these gestures. In this game the player is the goalkeeper of a football team and it has the job of defending as many shots from the opposing team as possible.

A goalkeeper is set out on the screen through goalkeepers gloves. The game has a background ambient sound of a football stadium, to increase the immersion of the game and gameplay. Figure 3.3 shows the goalkeepers gloves on the left and the football field on the right, the background of Guarda Redes.

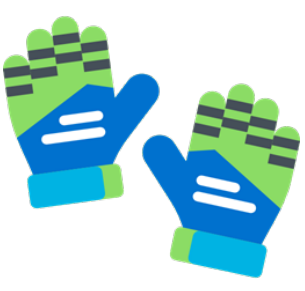

(a) Goalkeeper Gloves Sprite

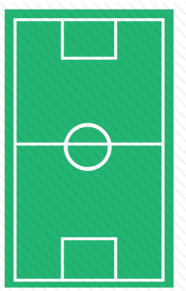

(b) Football Field Sprite

Figure 3.3: Goalkeepers Gloves and Football Field

Guarda Redes offers the players two game modes: General Mode and Lateral Defenses. General mode consists in defending the most amount of shots possible. This mode will start by making players defend left shots or right shots.

As the game progresses, more shots are added to the possible shots the player has to defend. So, the longer the user lasts, the more types of shots he has to defend. Shots are chosen randomly. Additionally, the user's time to react to a shot and defend decreases over time. 
In the second game mode, Lateral Defenses, the player will hear one or multiple shots coming from his left or his right and will have to defend the appropriate number of shots by performing one or two defenses. In the case of performing two defenses, the player cannot take his finger from the screen or it will be a goal.

We have developed these game modes so the player can validate their learning by having a mode in which their gestures will reward them or penalize them, as the other modes of training offered by Guarda Redes only focus on the gesture and not on the competitive aspect of the game. The difference between the two modes is that General Mode allows players to perform directional or L-shaped gestures and Lateral Defenses allows players to perform directional or back-and-forth gestures.

As the previous game mode, the longer the user is playing, the less time the user has to react to the shots. Finally, players are able to train a specific set of shots through a training mode we also developed.

Guarda Redes also offers a training mode to practise defending shots. Players are able to choose which set of shots they want to defend and enter a game mode with the shots they have selected. Although this mode has the same rules as the two main game modes, scores are not counted here. This mode is to specifically practice defending for the main game modes.

\subsubsection{Common Features}

\section{Tutorials}

The Tutorial is presented to the player the first time they open the game. The goal of the tutorial is to introduce the gestures the players will be using in the game. Also, the tutorial introduces the game's mechanics, sounds and menus. They are comprised of multiple parts, each teaching one key aspect of the game.

Each part of the tutorial asks for the player to perform a specific gesture. The gesture asked is related to a game mechanic or an aspect of the game. Finally, the tutorials also explain to the player how the game works and what options are available in each menu. In order to pass to the next part, the player has to perform the gesture asked correctly.

\section{Gesture Verification}

Treino Gestos is a mode offered in all games in which players are able to perform a gesture and get a visual and audible feedback of the gesture performed. In here, players are able to perform as many gestures as they want and are able to understand how the gesture they have performed is identified by the game.

We have introduced this mode to provide another source of feedback on the gesture performed as the only source that existed was the gameplay. By having a separate mode, 
players can focus on the gesture and understand how they can perform it better without worrying about the negative effect on the gameplay, if it is badly performed.

\section{Instructions}

Foguete and Corda have available a menu in which all the sounds of the game are displayed and able to be heard. As these games have the most amount of sounds, during the gameplay, we felt it was necessary to have a separate menu in which players would be able to listen to the sounds separately. This menu also has available the option Treino Gestos explained previously.

Guarda Redes however, as its gameplay does not involve as many number of sounds as the other two games, has a different view for the instructions. In here, players are able to select one shot or a set of shots and practice it in a simpler game mode, without uploading their session to the database.

\section{Score}

The main game mode keeps track of a score that is uploaded at the end of the game. This score can also be consulted by the player at any point, from the main menu. By doing this, we ensure the players always have an objective to play for, apart from practising their gestures. Also, by uploading it to the database, we can understand the player's history, in terms of games played.

Points are given based on a well performed gesture. However, there are more ways for the players to earn points. In Foguete, players also earn points for each enemy that passes their position without hitting them. In Corda, players also earn points for consecutive jumps.

\section{Gesture Explanation}

Our games also offer explanations about gestures outside the context of the game, that is, when using Google Talkback. As users are learning or practising the gestures, we felt it was also important to incorporate a method in which they would be able to understand what the gesture they are doing would do if they do it outside our games. To that, we display a menu in which users can select a specific gesture and be presented with a short description. 


\section{Chapter 4}

\section{Implementation}

In this chapter we will discuss the implementation of Games for Gestures. We will start by describing the implementation structure, going into detail about the different states of our games. After this, we will describe the common design aspects the games share and how we have implemented the gesture detection each game incorporates. After this, we will get into more detail about each game, explain their mechanics, development and aspects different between them.

\subsection{Overview}

Figure 4.1 shows the flow between the different states of our games. In here, we will describe how the states are related and how are players redirected between them. We will delve into what each state is responsible for later.

After opening our games, players are redirected into the Initial Message that displays the initial message. After hearing or skipping it, players are either redirected to the game's main menu or to the Gesture Performance state. If players are on the state GesturePerformance recording a set of gestures, after doing so will be redirected to the state Tutorial. This state only occurs once.

After players go through the tutorial, they are redirected to the game's main page. From this moment forward, after opening the game, players will be redirected to this state, instead of performing the steps described previously.

From the game's main page, which on Figure 4.1 corresponds to the state Main Menu, players are presented with the game's modes, with the option of going to the instructions and a third option of hearing their highest score, not displayed as it does not lead to a new state.

To play, players have to select the option play, which will redirect them to the state Gameplay. After losing, this state redirects players to the state GameOver, informing them about their game. Players will stay on this state until confirmation from the database is given that their game session was successfully uploaded. 
From the game's main page players are also to enter the instructions. To do this, players have to select "How To Play", entering the state How To Play. From this state, players are given the choice of entering Test Mode, a mode in which they can get audible and visual feedback about the gesture they are performing, with no gameplay.

Navigating backwards is possible between the menus of our games. In any menu, players can go to the previous page by pressing the native Android backwards button. The dashed lines present in Figure 4.1 illustrate the possible paths in which the user can navigate backwards. Also, if players want to close our games, from the main menu they can press the Android backwards button. It will ask them if they really want to leave and will remind them about how to turn Google Talkback back on.

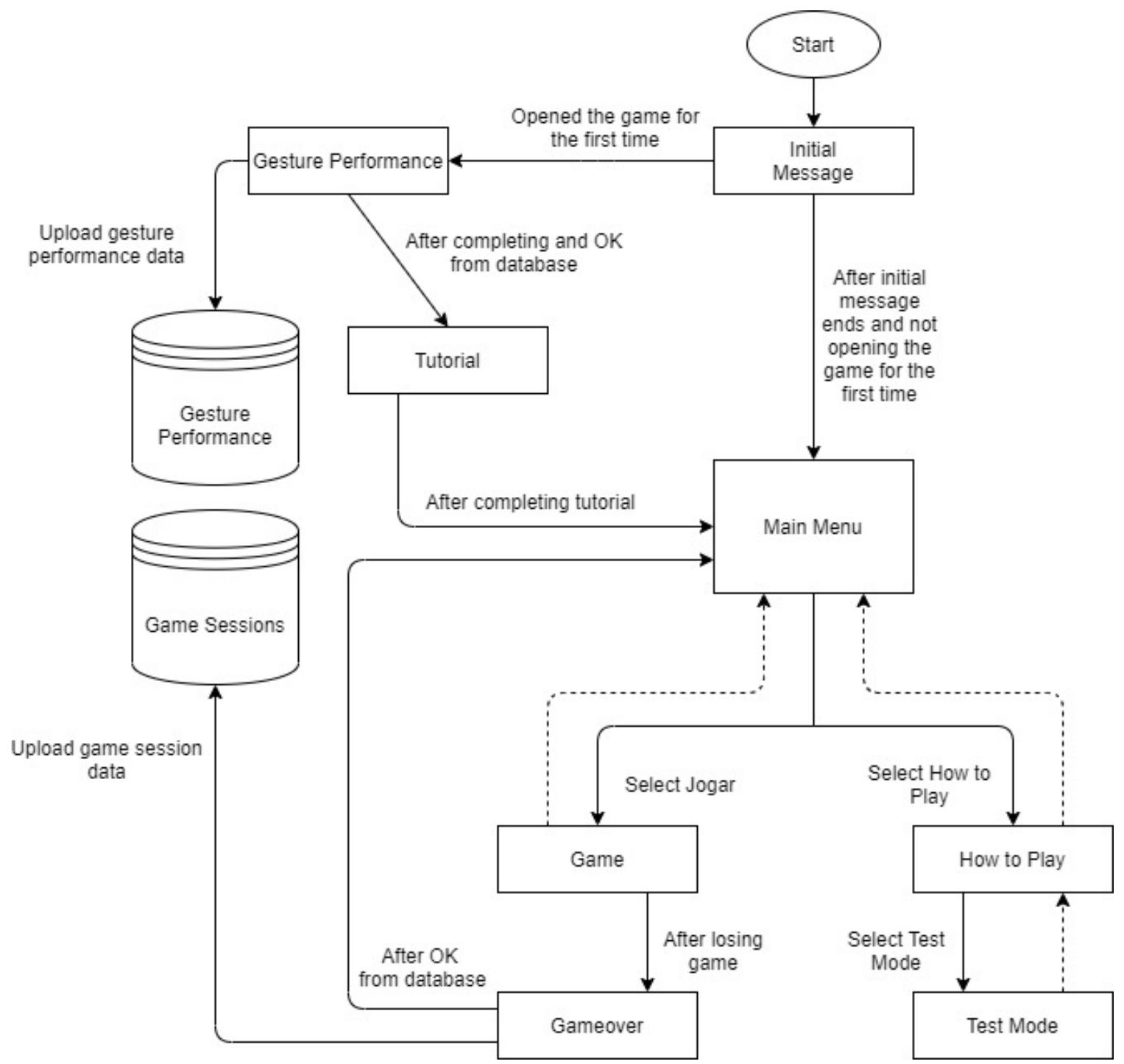

Figure 4.1: Flow Diagram 


\subsection{Unity}

Unity ${ }^{1}$ is a cross-platform game engine developed by Unity Technologies, first announced and released in June 2005. Unity is able to provide many of the most important built-in features that make a game work: physics, 3D rendering and collision detection. By providing them, developers do not need to create them from scratch. Unity also has available an "Asset Store", in which developers can find free or paid creations uploaded by the community. These are easily imported into any project.

\section{Toggle Buttons}

We used the Unity plugin DOTween (HOTween v2) $2^{2}$ to implement toggle buttons in Guarda Redes, as we offer the players the possibility of selecting and combining the types of shots they want to practice.

\section{Notifications}

We used the Unity plugin SimpleAndroidNotifications ${ }^{3}$ to implement the notifications displayed for our users. This plugin allows to create personalized notifications with different colours, shapes and messages through a set of functions.

\section{Rest Client}

We used the Unity plugin Rest Client for Unity ${ }^{4}$ to communicate with our databases. This plugin offers the default HTTP methods and callbacks for confirmation of successful or error operations, allowing us to confirm the information sent and if that information was sent successfully.

\subsection{Common Design Aspects}

\subsubsection{Game States}

We have created the structure GameManager that is composed by the game's states described previously in section 4.1. In here, we will delve into each state of our games and explain what they are responsible for and how the transitions between stats occur. 2020)

${ }^{1}$ Unity https://unity.com/products/unity-platform (Last visited on October 5th,

${ }^{2}$ DOTween (HOTween v2). https://assetstore.unity.com/packages/tools/ animation/dotween-hotween-v2-27676 (Last visited on January 10th, 2021)

${ }^{3}$ SimpleAndroidNotifications. https://assetstore.unity.com/packages/tools/ integration/simple-android-notifications-free-68626 (Last visited on January 10th, 2021)

${ }^{4}$ Rest Client for Unity. https://assetstore.unity.com/packages/tools/network/ rest-client-for-unity-102501 (Last visited on January 10th, 2021) 
The first state we delve into is the state Initial Message. This state is responsible for displaying the initial message that is presented every time players open the game. This message informs the player that in order to play the game they have to turn off Google Talkback and use headphones. To this, we provide instructions about how to turn if off.

After hearing or skipping the initial message, players are redirected to the state Gesture Performance, responsible for recording the participants gestures. As mentioned earlier, this state is responsible for guiding the players into performing the set of gestures specific for each game. After this step, their gesture performance data will be uploaded to the database. After a successful upload, players are presented with the game's tutorial.

The state Tutorial occurs only once, after the players performed the gesture performance and it teaches the player the basics about the game. The tutorial is comprised of multiple parts, each responsible for teaching one key aspect of the game, from directional movements to boundaries and general information about how the games work.

After players do the tutorial, they are finally presented with the game's main menu, corresponding to the Main Menu state. In here, players are presented with the game's modes, corresponding to the state Gameplay, with an option to learn how to play, the state How to Play and another option of checking their score, not displayed on Figure 4.1 as it does not correspond to a new state.

If players choose to play, they are redirected to the state Gameplay, responsible for all visual and audible components used during a game session and for every interaction that occurs while playing. When players lose, they are redirected to the state GameOver.

The state GameOver displays an image that illustrates the end of the game and inform the user about the statistics of the game that was played. In addition, this state is responsible for informing the players if they have achieved their daily goal and for uploading their game sessions to the database. After the game session is successfully uploaded to the database, the game redirects the player to the state Main Menu, the game's main menu.

On the main menu players also can learn more about the game. To do that, players choose the option How to Play. This state presents the game's sounds and provides with a short explanation about the type of situation they might occur in-game.

\subsubsection{Gesture Recognizer}

Each of our games implements a gesture recognizer responsible for detecting and interpreting every interaction performed. Every interaction has an outcome depending on the state the player is in. All throughout our games, either on the game's modes or on the menus, we are able to detect all gestures. However, there are some contexts in which some gestures are not interpreted.

Regarding Foguete and Guarda Redes, interactions such as taps, double-taps, longpress and drag are not interpreted while the user is playing as these gestures do not have any effect on the gameplay of those games. On Corda, all types of swipes are not detected 
while playing as, once again, those gestures are not reflected in any aspect of its gameplay.

On the menus of each game the only gestures interpreted are taps, double-taps and drag. This is because our games offer Explore By Touch as way to navigate. Gestures such as swipes are not interpreted on the menus.

\subsubsection{Interface}

\section{Supporting Screen Reader Gestures}

Google Talkback does not recognize objects that Unity renders as Buttons, Labels or other types of rendered objects. Google Talkback only works when the rendering of the $\mathrm{UI}$ is done natively by the operating system. As a consequence, our games have to be able to detect the gestures without the screen-reader. And so, on the first screen shown to players we ask them to turn off Google Talkback to play our games. We do that with an initial message, displayed every time they open our games.

This message informs and asks players to turn off Google Talkback and to use headphones and it is both visually and audibly available. Also, this message also explains how to navigate through the games using Explore by touch and where all the buttons are located so navigation can be easier. Figure 4.2 shows all three initial messages shown in our games.

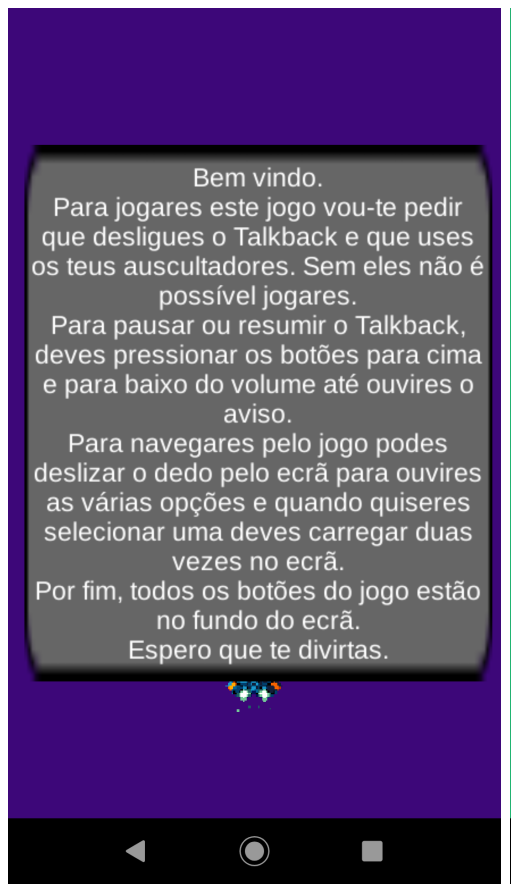

(a) Initial Message - Foguete

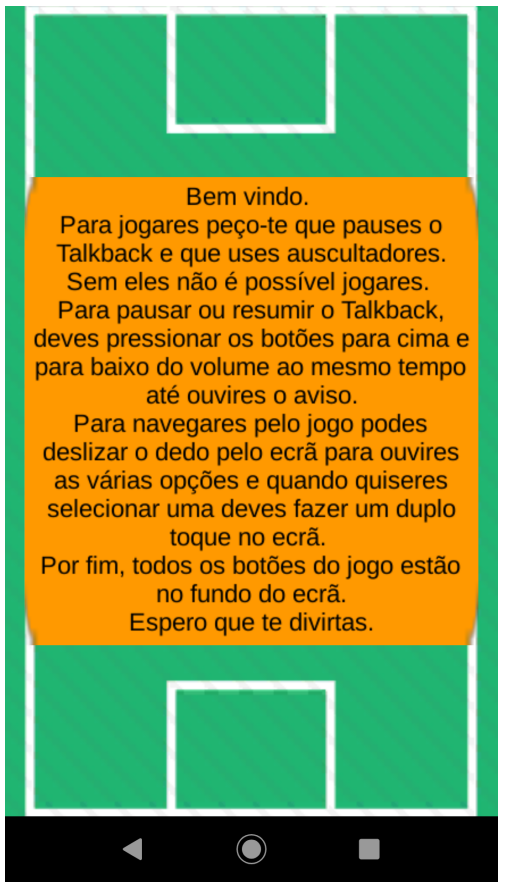

(b) Initial Message - Guarda Redes

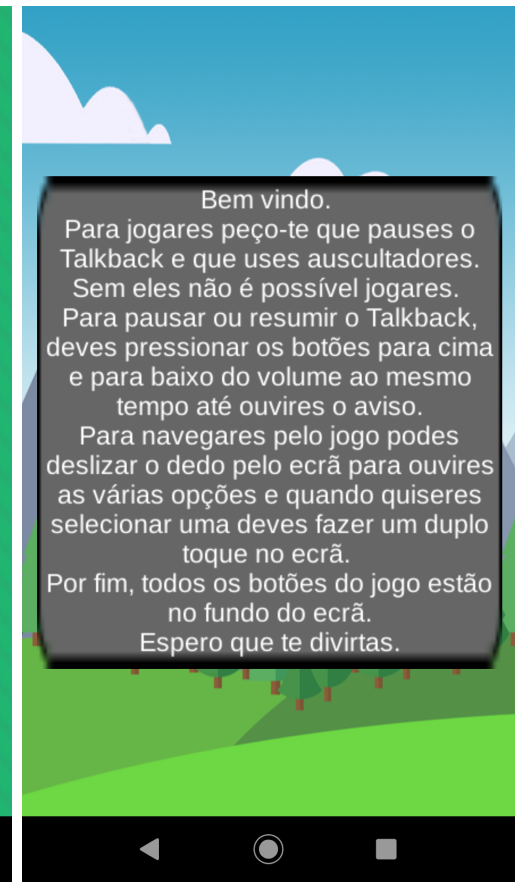

(c) Initial Message - Corda

Figure 4.2: Initial Screens - Foguete, Guarda Redes \& Corda 


\section{Combination of Shots}

Guarda Redes offers a mode in which players can train one or a set of shots. This mode allows for the players to select a combination of their choice, meaning, they are able to train the gesture or set of gestures they want. To implement this, we have used multiple toggle buttons, which allow for multiple options to be activated and deactivated as toggle buttons are part of Android's menus and so, players are familiar with them.

To activate or deactivate a type of shot, players perform a double-tap on the option. An audio-cue is played confirming their action. When the player performs a double-tap and the toggle button is deactivated, it will move to the right meaning that it is activated. The opposite occurs for when the button is active and players deactivate it. To create these toggle buttons, we have used the plugin DOTween (HOTween v2) explained previously.

Figure 4.3 shows the deactivated toggle for the type of shot Defender Para Cima on the left and its state after being activated, on the right. This figure also shows the button Treinar Todos, important for this mode as well. This allows for the players to select all shots at once instead of selecting one by one. When selecting this button, it will activate all the buttons present on the page. If this button is select with one or multiple buttons active, those will become inactive.

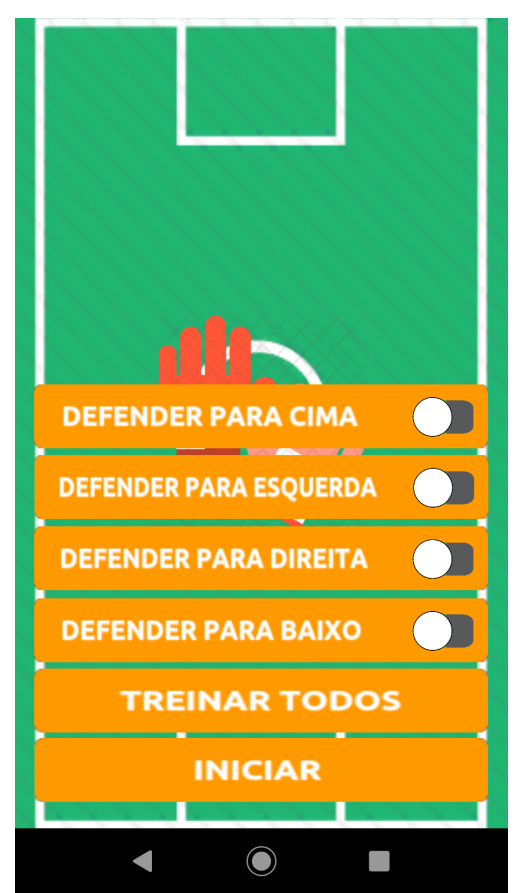

(a) Toggle Button - Deactivated

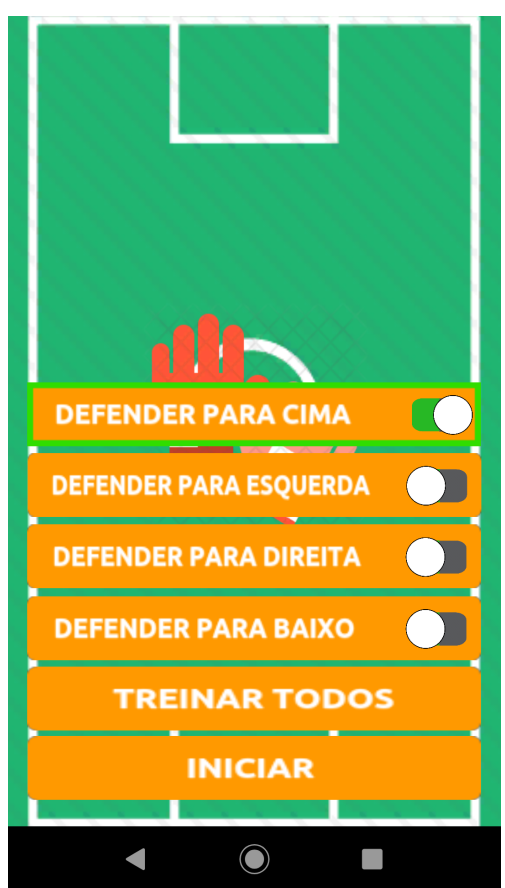

(b) Toggle Button - Activated

Figure 4.3: Guarda Redes - Toggle Buttons 


\section{Notification System}

To inform the users that they have completed their daily goal of a number of games played we have implemented mechanism to inform users through a notification on their smartphones. Upon the completion of that objective, a notification will be displayed on the screen.

The motivation to implement notifications was concerned with our study. We felt that asking participants to play five daily games would be a reasonable amount of effort and time spent playing our games and also result in a representative number of daily games played. And so, players do not need to keep track of the amount of games they have played, our system takes care of that and informs them.

To create the notification displayed in figure 4.4 we have used the plugin SimpleAndroidNotifications explained previously. This provides the function Send with the following set of parameters:

Send (TimeSpan.FromSeconds(1), "Bom trabalho!”, ”Fizeste os 5 jogos diários!”, Color:Red)

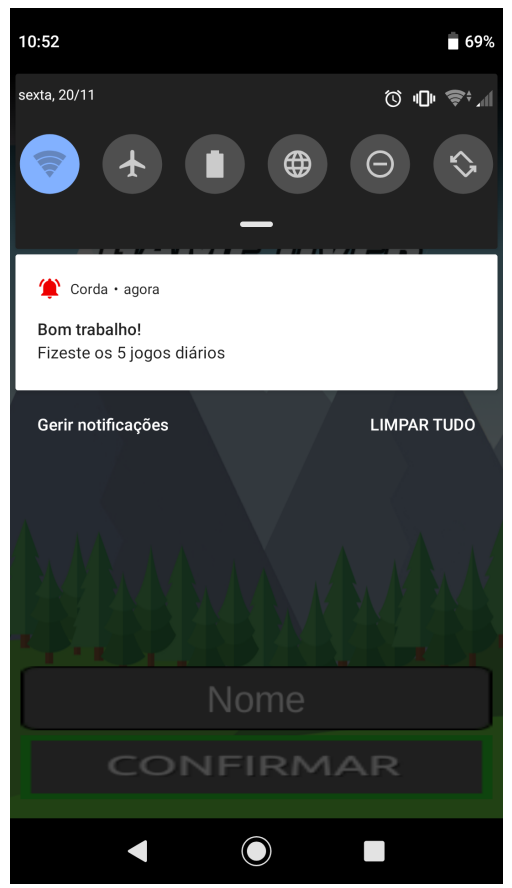

Figure 4.4: Daily Games Notification System

\section{Foguete's Screen lanes}

As mentioned earlier, we have divided the screen in three vertical areas or lanes: left, center and right. Visually, each of these areas is responsible for displaying multiple enemies, spaceships, asteroid or bonus points. The process of displaying the objects of the game will be explained later. 
When playing our game mode we present three components on top of the screen: Tempo, Pontos and Vidas. Figure 4.5 displays these components. From left to right, Tempo shows the time of a game session, Pontos shows their current score and Vidas displays how many lives the player has. These provide information to the player both visually and audibly: during the game the player can check this information by dragging a finger above each of these components, although they are mostly used as visual feedback.
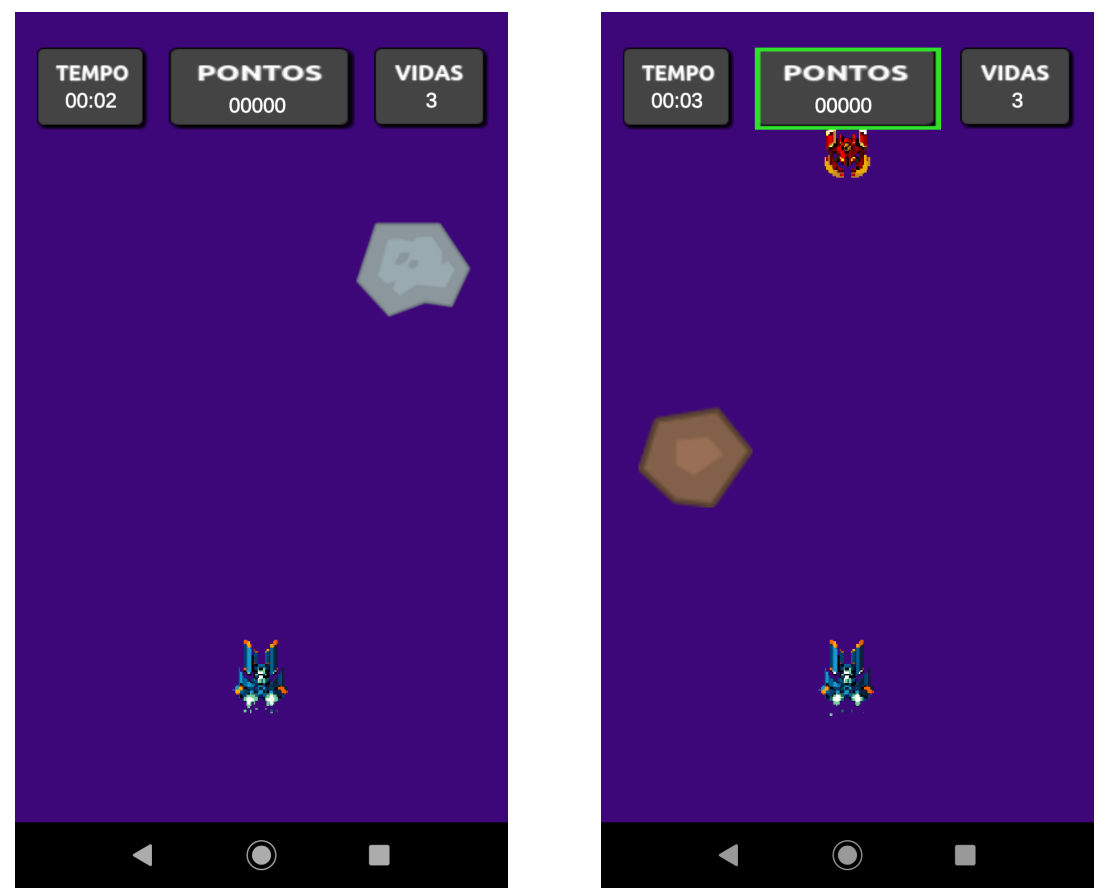

Figure 4.5: Foguete - Screen Lanes

\subsubsection{Sounds}

To produce text-to-speech sounds we used Amazon Polly 5 web service. Polly is a service that turns text into lifelike speech. Every audio file informing the player about any aspect of the game was produced using Polly. These sounds are used on the opening message, on the tutorials, to provide Explore by Touch and on any other explanation we provide to the player.

\footnotetext{
${ }^{5}$ Amazon Polly https://aws . amazon. com/polly/(Last visited on 5th February, 2020)
} 


\subsection{Gesture Implementation}

\section{Touch}

Unity has a similar interpretation of the Motion Event, Touch 6 . When the user touches the screen, a Touch structure describing the status of a finger touching the screen is defined. This structure includes the touch's phase, position and whether it was a single contact or several taps, amongst other properties. More particularly, a Touch's phase is defined by five properties:

- TouchPhase.Began: triggered when a finger touched the screen;

- TouchPhase.Moved: triggered when a finger moved on the screen;

- TouchPhase.Stationary: triggered when a finger is touching the screen but has not moved;

- TouchPhase.Ended: triggered when a finger was lifted from the screen, as the gesture is ending;

- TouchPhase.Canceled: triggered when the system cancelled tracking for the touch.

Our method of detecting the gestures works similarly to the method described above in section 3.5.1. When the user touches the screen, TouchPhase.Began is triggered and the starting touch's $\mathrm{x}$ and $\mathrm{y}$ positions are stored as well as a timestamp.

This phase also detects double-taps: for each time this phase is triggered, we will be comparing the current timestamp with the previous timestamp. If the difference in milliseconds and the distance in pixels between the two touches is within the thresholds, then a double-tap was performed. If a double-tap is triggered, even if TouchPhase.Moved is triggered, the gesture performed is considered to be a double-tap.

\section{Angle measurement}

TouchPhase.Moved is triggered as the user is dragging a finger on the screen. On this phase of the touch we calculate the angle between the current touch's position on the screen and the initial touch's position on the screen and if the swipe being performed has the length of at least the threshold defined for the length of a swipe. This angle allows us to define a direction for which the user is performing the gesture. This direction is used for us to analyse whether the user is performing a swipe accepted by our games.

To measure the angle between the current touch and the initial touch, we use the function Atan2(float y, float $x$ ) from the class Mathf. It returns the value between the $\mathrm{x}$-axis and a vector starting at zero and terminating at $(\mathrm{x}, \mathrm{y})$. This means any gesture performed on any part of the screen is transformed into a vector starting at zero regardless where they are performed and all gestures are measure equally.

\footnotetext{
${ }^{6}$ Unity Touch https://docs. unity3d.com/ScriptReference/Touch.html(Last visited on October 5th, 2020)
} 


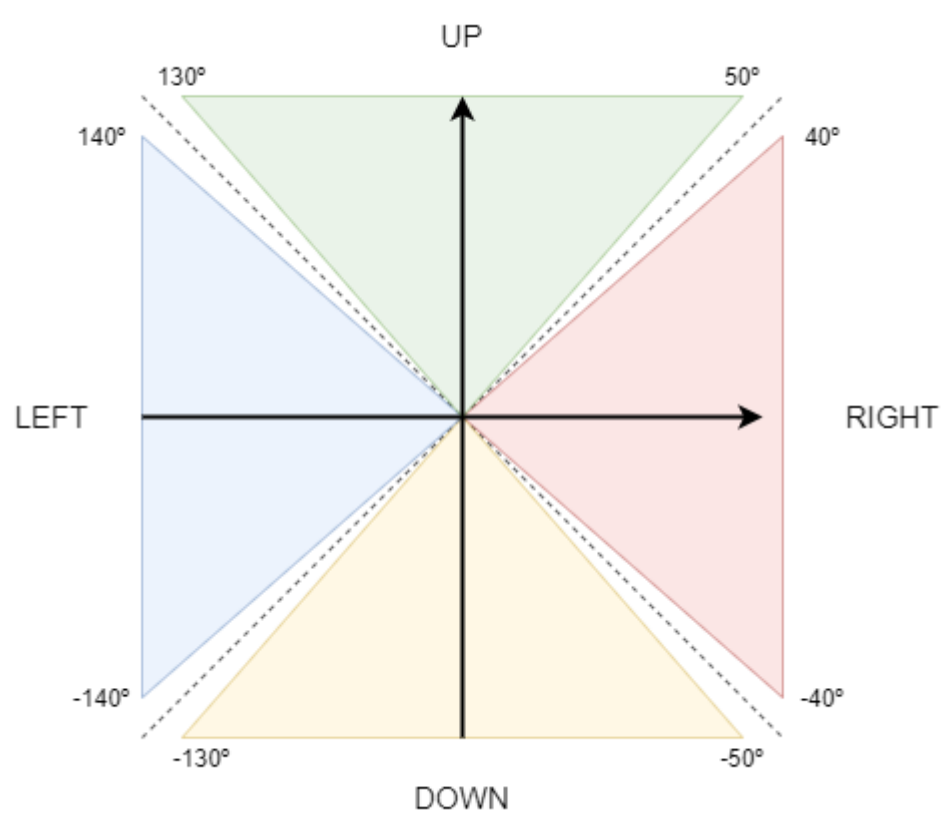

Figure 4.6: Amplitude of the angles measured

While doing this implementation, we have noticed that there is a window of amplitude in which Google Talkback does not recognize diagonal swipes. For instance, if the user performs a diagonal swipe to the up right corner of the screen, there is a small window of amplitude in which that swipe is not recognized as an up swipe or a right swipe.

Figure 4.6 displays the areas used to determine the direction of a swipe and their amplitudes. Each area has an amplitude of $80^{\circ}$. There is a difference of $10^{\circ}$ of amplitude between each of the areas displayed. This difference is our implementation of that small window of amplitude explained previously.

A directional swipe performed in any of these areas will only have the direction of the area it was started in. Even if it starts in one area and ends on another, the initial direction calculated will be its direction. The red area is located between the angles of $40^{\circ}$ and $-40^{\circ}$. The green area is located between the angles of $50^{\circ}$ and $130^{\circ}$. The yellow area is located between $-50^{\circ}$ and $-130^{\circ}$. The blue area is located between $-140^{\circ}$ and $140^{\circ}$.

\section{Detection of L-shaped Gestures}

The detection of an L-shaped gestures has an additional step: the verification of the next direction. For the first part of the swipe, we detect one direction in which the swipe is being performed. For an L-shaped gesture, we have to detect two directions and in both directions the swipe performed has to be greater than the threshold for the length of a swipe.

To do this, we measure the perpendicular angle between the current touch and the previous touch, however with a slight change. The perpendicular angle we measure is 
narrower, it does not have the amplitude of $80^{\circ}$ as the angles measured before. This measurement gives us an approximate point in which the swipe performed has turned direction.

We have done this because of two reasons: the first is that it would make more difficult for diagonal swipes to be detected and the second is because L-shaped gestures would have to be performed more correctly, resembling more an L instead of just a curved gesture in two directions.

After an L-shaped gesture is performed, we end up with two directions. Those two directions will correspond to the gesture performed. For instance, if the user has performed an L-shaped gesture to the top right corner of the screen, we will end up with the directions of up and right. This order also confirms the gesture performed was a swipe up then right.

\section{Detection of Back-and-Forth Gestures}

The process of detecting a back-and-forth gesture is similar to the process of detecting an L-shaped gesture. On this case, if the user is performing a swipe left or a swipe right we are also analyzing the amplitude of the gesture between the current position and the previous position. If we detect a completely opposite amplitude, this means the user has performed a gesture in another direction and then, this part of the gesture was performed in the opposite direction.

For instance, if we detect an amplitude between $140^{\circ}$ and $-140^{\circ}$ after performing a right gesture, this means the user has performed the back-and-forth gesture right-left. Similarly, if we detect an amplitude between $40^{\circ}$ and -40 after performing a left gesture, we have detected the back-and-forth gesture left-right.

\section{Gesture Validation}

When the user lifts his finger from the screen, the gesture has ended and TouchPhase.Ended is triggered. In here, we perform the set of actions to validate the gesture performed.

We start by calculating the swipe's distance, in pixels. The distance of a directional swipe left, right, up or down is obtained by the sum of the distance on the $\mathrm{xx}$ and $\mathrm{yy}$ axis. To calculate the distance of a L-shaped swipe, we sum two distances: the distance between the initial point and the point in which the direction has changed and the distance between that point and the final point of the touch.

After calculating its distance, if it is larger than the minimum threshold for a length of a swipe, we will calculate the gesture's velocity. To do this, we divide the distance for the duration of the swipe. The duration of the swipe is measure as the difference between the time in which TouchPhase.Began was triggered and the time in which TouchPhase.Ended was triggered. 
If the gesture performed by the user was a correct gesture in terms of its velocity and distance thresholds, then the performed gesture is valid and the action associated with that gesture occurs.

The implementation we have described to detail previously was implemented as close as possible to Android's Gesture Detector. To verify if a gesture is valid we are following the thresholds defined by Android's Gesture Detector. In addition, to improve our gesture detector we also took in consideration Google Talkback and the amplitudes in which it might not detect a swipe. This ensures us that the gestures we are monitoring and identifying in our system would be identified in Android's system the same way.

\subsection{Gesture Collection}

This is the initial step of any of our games. As our study had to be conducted remotely, we had to develop the initial gesture detection in a way this initial step would be done remotely. To achieve this, we have developed it so players would start any game for the first time and would guided into performing a set of gestures related with the game they are playing.

Gesture Detection in each game works similarly: users are given a version of our games with an embedded participant id that uniquely identifies them and then are guided into performing the gestures.

Every interaction is recorded. Generally users touch the screen a few times or perform the gesture incorrectly before performing it correctly, so all touches are recorded and stored.

Our games ask users to record different sets of gestures, the set of gestures each game is focused on practising. Foguete asks users to perform left and right swipes. Guarda Redes asks users to perform up and down, L-shaped and back-and-forth swipes. Corda asks users to perform double-taps. However, all gestures can be detected and recorded by each game.

The process of Gesture Collection works as follows: first, participants will be explained what gesture they will be performing and they have to perform it after hearing a beep. They will also be explained they have to do that gesture for 10 times. Once 10 gestures are performed, either the user will be guided to the next set of gestures to be performed or this initial step is ended and information about the gesture performance is uploaded to the database.

If in any step a gesture is not performed, participants are informed about which gesture they have to perform and how many time they still have to perform it.

After each interaction or gesture performed, a timer of half a second is started. If another interaction within that time interval is detected then the timer is reset and will start again once that interaction ends. Once the timer ends and no other interactions are 
recorded, the next beep will be played.

\subsection{Tutorials}

As explained before, the tutorials are comprised of several parts, each responsible for teaching one key aspect about the game. Tutorials teach the players about the game's mechanics, sounds and overall menus and occur only one time, the first time the player opens the game.

In each part, the player listens to an audio cue explaining the gesture he is about to perform and the effect of it in game. If by performing that gesture a sound cue is played, the player will be told that upon performing the gesture.

While the player is listening to the information, before performing a gesture, they are not able to perform any gesture on the screen. Conversely, players are only able to perform the gesture when specifically told to.

If the player performs the incorrect action or does not perform any action at any part of the tutorial, that part of the tutorial is played back again and the player is asked to repeat that action. Once the player successfully performs the gesture he is asked too, he will be redirected to the next step or to the main page of the game.

Each part of the tutorial is responsible for checking if the gesture performed was the correct for that part. So, any gesture detected different than the expected gesture will lead to the repetition of that part of the tutorial.

In here, we will provide with a short script of Corda's tutorial. Appendices $A$, B and $\mathrm{C}$ provides the full description of the tutorials of Corda, Foguete and Guarda Redes, respectively.

The player has finished recording a set of gestures. After that, an option to enter the tutorial will appear on the screen. After entering the tutorial, this is the first instruction the player will hear:

"Vamos saltar à corda! Para obteres a melhor pontuação terás de saltar no melhor momento. A corda não vai parar, vamos ver quanto tempo aguentas. Primeiro vamos ver como podes saltar. Um toque no ecrã significa que estás a levantar uma perna. Para isso, deves tocar uma vez no ecrã: experimenta."

Once this instruction ends, the game will wait for an interaction, meaning, a touch. If the player touches the screen, then the next instruction is the following:

"Quando tocas apenas uma vez no ecrã vais tropeçar na corda e terás de começar o jogo de novo. O mesmo acontece se não tocares no ecrã. Agora, para saltares tens de fazer dois toques rápidos seguidos no ecrã. Ou seja um duplo toque. Experimenta.” 
However, if the player does not touch the screen for a while, the player will be informed that should have touched the screen and that will repeat this part of the tutorial, as follows:

"Não tocaste no ecrã. Se não saltares irás tropeçar na corda. Vamos tentar novamente. Para levantar uma perna deves tocar uma vez no ecrã: experimenta."

In addition, the player might have performed another gesture such as a longpress or a swipe. If this occurs, then the player will repeat this part of the tutorial and will hear the following instruction:

"Fizeste um toque muito longo no ecrã. Deves fazer um toque mais curto. Vamos tentar novamente. Para levantar uma perna deves tocar uma vez no ecrã: experimenta."

\subsection{Foguete}

Foguete is based on the classical game Asteroids. As we have explained previously, visually the screen is divided in three vertical areas or lanes: left, center and right.

When the game starts, a clock is started and a timer of 7 seconds is started. This timer increases the enemies speed by 0.2 and decreases the interval for spawning an enemy by 0.3 seconds. Also, it increases the enemies' sound pitch by 0.05 until it reaches the maximum of 1.1. We have determined this maximum value for pitch as any higher it would make the sound unrecognizable. This means that every 7 seconds enemies will be travelling faster down the screen and as their speed increases, their pitch increases as well.

Additionally, every 7 seconds the interval in which enemies are spawned decreases: the maximum value of the interval decreases 0.3 and the minimum value increases 0.1 . With this, enemies' spawn rates will be comprised to a smaller interval and enemies will spawn faster.

At the same time, one of the three lanes is chosen randomly to spawn the first, second and third enemies. Once that initial order is established, the first will spawn 1.5 seconds after starting the game, the second will spawn from 2.5 to 3.5 seconds after the first enemy is spawned and the third will spawn an enemy from 3.5 to 5 seconds after the first enemy spawned. As each lane spawns enemies randomly and occasionally enemies are not spawned, the order of enemies spawning does not remain for the rest of the game.

Players will be given 100 points if successfully dodge an enemy or get the bonus. By performing a swipe, the player moves its ship to one of the adjacent areas. However, if the player is located on the left or right areas, he cannot move again in the same direction.

Also, one directional swipe left or right is equal to one movement. So, the player's ship only moves horizontally left or right and never moves vertically. 


\section{Spawning Enemies, Rocks and Bonus}

Each lane is responsible for spawning an enemy or bonus in the same coordinates inside their respective area. Enemies will spawn on the top part of the screen in the same position within their area and will not spawn near the player's ship.

Enemies or bonus points are spawned if the following conditions are met: the last object spawned has passed the player's ship and if there are no other objects inside the first third of screen, horizontally. If one of the conditions mentioned earlier is not met, then the spawn is delayed.

By doing this, we make sure that only one enemy or bonus is spawned at a time, therefore not creating a block of two or more objects. When spawning an enemy, each enemy is spawned 1.5 seconds to 6 seconds after the previous enemy. This interval decreases every 7 seconds until it reaches the interval of 0 to 2 seconds for enemy to be spawned.

To choose between an enemy, asteroid or bonus points we have defined a set of values to make the choice random. The odds of spawning an enemy ship are of $20 \%$, the odds of spawning an asteroid are of $75 \%$ and remaining $5 \%$ are for point boosts.

Each area of the screen is also responsible for spawning its type of enemy. Enemy spaceships, asteroids and bonus points are Prefabs, game objects which have components, property values and child game objects.

\section{Audio manipulation}

We have created multiple instances of enemies and bonus points which are almost identical with the exception of one aspect: the value of stereo pan. Stereo pan defines from which side the stereo sound will be outputted. Enemies and bonus points spawning from the left area will have this value set to -1 , enemies spawning from the center area will have this value set to 0 and enemies spawning from the right area will have this value set to 1 .

The division of the screen in three separate areas also allows for more precise control of movements and actions: when the player swipes left or right, it moves a specific distance to the adjacent area of the swipe's direction. When in the right area, the player cannot swipe right again. When in the left area, the player cannot swipe left again. The player is able to swipe consecutively to one side if its spaceship starting position was on the left or right area.

\section{Visual Elements and Animations}

As we are developing audio games, it is also important for our games to have visual components. Even though these are not mandatory, their existence helps players to understand any aspect of the game and to share experiences or concerns with others. Also, 
it helps for other players to understand what's going on. Audio games only recurring to audio may prevent experiences to be shared or help to be provided.

To make spaceships, both player's and enemies, and explosions we have produced animations for their movement. Unity allows for the creation of an animation through a set of images played in a short amount of time defined by the user. We have created animations for the player's spaceship, for the enemies and for explosions through a process we will explain next.

Figure 4.7 shows the sprites used to make the player and enemy spaceship animations and figure 4.8 shows the sprite used to make the explosion animation.
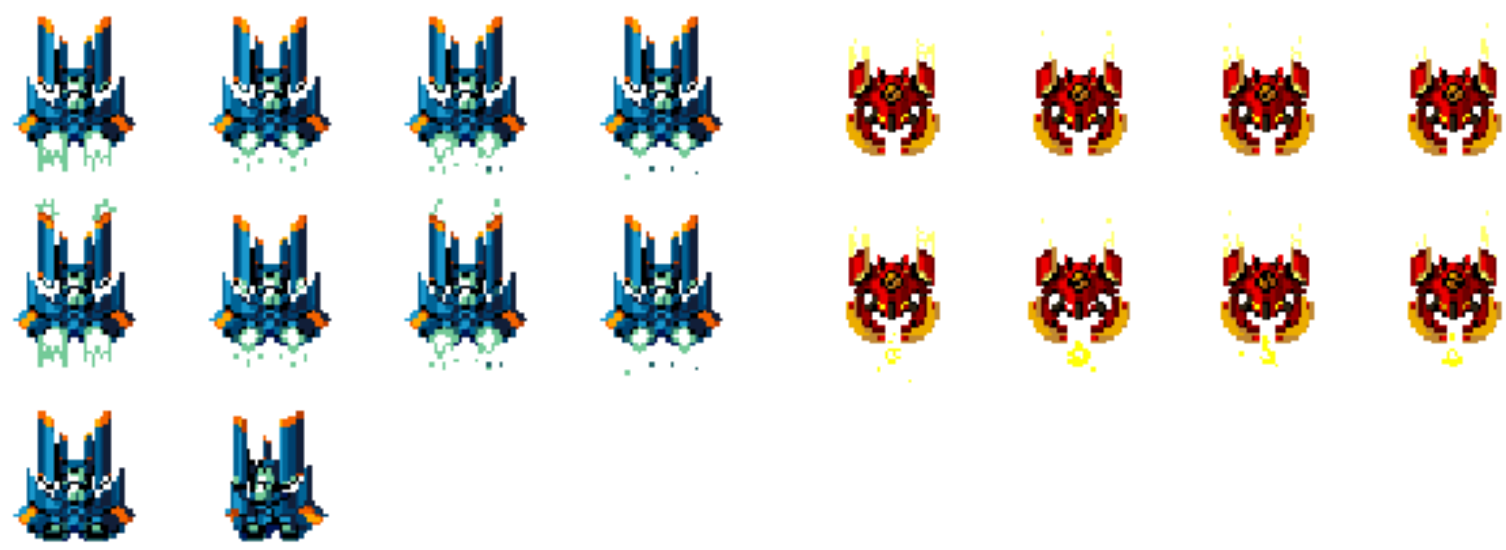

(a) Player Ship sprites

(b) Enemy Ship sprites

Figure 4.7: Player and Enemy Spaceship sprites

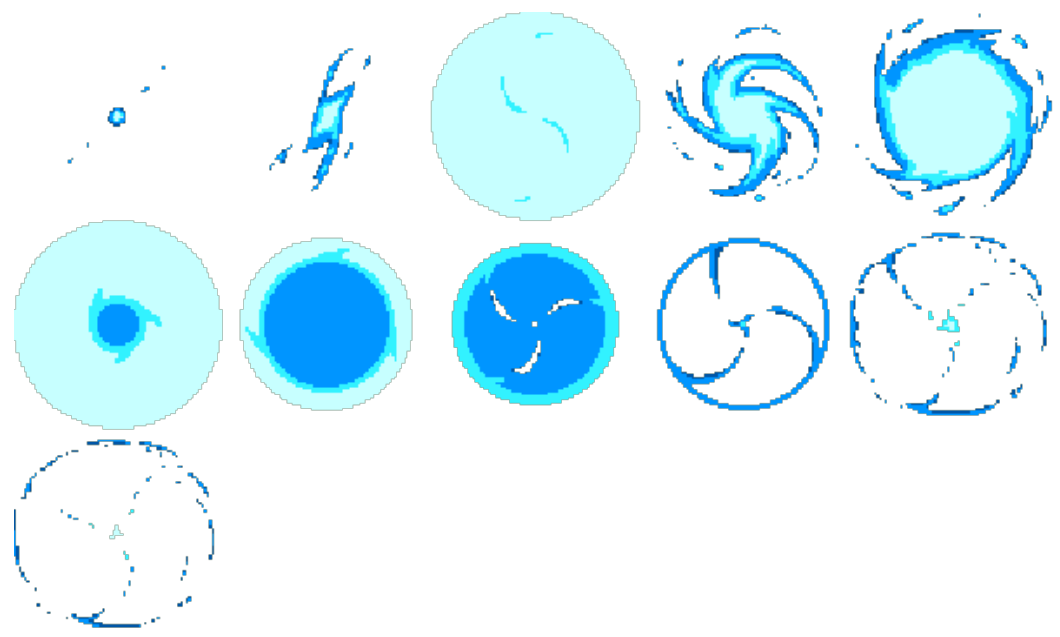

Figure 4.8: Explosion sprites

After importing all the sprites for our animations, for each sprite we changed the 
property of Sprite Mode from Simple to Multiple. This creates multiple sprites under the same asset instead of creating one asset based on the whole initial sprite. For example, for our explosion sprite, instead of having only one sprite after this step we have 11 sprites. After that, we used Unity's Sprite Editor menu to slice each of the initial sprites into several sprites. Now, each of those multiple sprites will be a part of the animation. Our next step was to change the filter mode to point, the least consuming rendering mode to our sprites as it there are not any advantages in using any of the other filter modes, bilinear or trilinear.

After editing the sprites, the next step was to create the animation. To create each animation we have selected which images we want the animation to be composed with and drag them to the Hierarchy section in Unity's main menu. Unity also creates an Animation Controller file that allows to arrange and maintain a set of Animation Clips and associated Animation Transitions for a character or object of our game. However, in our game there are no specific conditions in which our animations have to change.

\subsection{Guarda Redes}

Guarda Redes offers a visual representation through a set of goalkeepers' gloves. The gloves are located on the center of the screen and they can be moved to the position which the user wants to defend. After each defense or goal, the gloves are placed back to their normal position, the center of the screen.

When starting each of the game modes, a whistle is played. This whistle means the game is going to start and the shots will be taken. The player will only hear whistles again on the end, after conceding 5 goals, meaning he has lost the game.

When the player hears the shot, a timer of 3 seconds is started. These 3 seconds are the time interval the player has to perform a swipe to defend the shot, otherwise it will be a goal and a sound cue resembling a football commentator match is played, informing the player in which direction the goal was conceded.

This timer stops once the user finishes the swipe that is performing or when the time has passed. As soon as the player lifts the finger from the screen, the timer ends. Once it ends, it will check if the swipe made was the correct swipe for the shot.

For a swipe to be a successful defense it has to be correct not only in direction from which the shot is listened but also in terms of the swipe characteristics. If not, a goal is conceded. The player will lose once after conceding 5 goals. After losing, the display will change to illustrate the player has lost and will hear the final score, the number of shots defended and their game session will be uploaded. 


\section{Game Modes}

As we have said earlier, Guarda Redes has two game modes: the Main mode and Lateral Defenses. These modes differ on the amount of shots the player will hear before defending.

In the main mode the player will only listen to one shot at a time and can only do one defense for each shot. Initially, the player has to defend shots to his left or to his right. Every 20 seconds a new type of shot is introduced for the player to defend until all types of shots are introduced, starting first with the shots that are defended with simple swipes and then shots that are defended with L-shaped swipes. For instance, 20 seconds after the player started playing this mode, the shot down is introduced and the player will have to defend three types of shots: left, right and down.

Once all the shots that can be defended with simple swipes are added, shots to the corner of the screen are added. These are: top right corner, top left corner, bottom left corner and bottom right corner.

In the mode Lateral Defenses the player can listen up to two shots but can only perform one defense. Unlike the previous mode, in here the player from the beginning will have to defend all types of shots available: left, right, left then right and right then left. If the player misses defending both shots, it will count as two goals conceded. To perform a left then right or right then left defense, the player cannot lift the finger from the screen.

In both game modes shots are chosen randomly from the set of shots available. Also, introducing a new shot is also random, so the order of shots introduced from game to game is different. This does not apply to the mode Lateral Defenses as all the shots are available from the moment the player starts playing.

\section{Audio Manipulation}

In Guarda Redes a shot is a sound cue with different values of pitch and stereo pan. The pitch attribute of a sound cue allows to slow down or speed up the sound. We use this effect to modify shots going above the goalkeepers' head or below the goalkeepers' legs: for the shot to go above, we increase its pitch. For the shot to go down, we decrease its pitch.

As explained before, the attribute stereo pan defines from which side the stereo sound will be outputted and can have three values: -1 for left, 0 for center and 1 for right. So, for example, to play a left shot we play a sound cue with pitch equal to 1 and stereo pan equal to -1 .

\section{Sounds}

There is a set of sounds that is specific to Guarda Redes. These mimic an old-radio broadcaster of a football match, announcing the goals conceded by the player and give 
another level of depth to the game, alongside with the background sound effect being played on the background. To create these sounds, we had to perform multiple recordings and then modify them using a filter to get the effect intended. The first step was rather simple, as we have used a simple sound recorder. For the second step, we have done some investigation into how we could create an old-radio broadcaster filter. To create the filter, we used Audacity. Then, the final step was to upload our recordings into Audacity and alter them with the filter.

\subsection{Corda}

Corda is an audio game with no visual representation. Our first goal was to search for a sound to play on background that would give the user a sense of being on a playground playing with friends. Sounds counting perfect jumps also were modified to sound like being done by children.

A touch on the screen means that the player is lifting one of its legs to jump. To jump correctly, a double-tap is required. A sound cue is played for every touch on the screen the user performs and if a double-tap was performed, the player will listen to a sound of hitting the ground, as if the player has landed on the ground after jumping.

The sound of a rope hitting the ground is part of a one second loop: every second, the player will hear it. After hearing it, the player is given a one second timer to jump, otherwise loses a life. Jumping too close to the end of this time interval will make the player lose, as there is no time left to perform the double-tap.

The game will start after the player's first touch. Throughout the game the player has three lives. After each life, the game only starts after the user's first touch. This simulates the effect of watching the rope being played but choosing when to enter and jump.

Once that time has passed, the function will continue its execution and will perform the actions described previously. However, if the user taps the screen the its execution is canceled.

When the user taps the screen another timer is started. This timer will check if the difference between the first touch and the second was less than 0.300 milliseconds, the threshold of time difference between the first and the second touch for this gesture to be identified as a double-tap.

If this timer ends and no double-tap was performed, then the game ends. However, if this timer ends and the user has performed a second touch then the user has performed a correct double-tap and he will be rewarded: the game will play a reward sound, meaning the player has successfully performed a double-tap and it will start the counting of perfect jumps.

Every time the player performs a perfect jump he will be rewarded with 100 points and will hear a sound cue indicating he has performed a perfect double-tap or jump. Every 
five perfect jumps the game will tell to the player the current number of jumps and the interval to play the next rope sound cue will decrease, meaning the player will have less time to perform the gesture.

When the player loses the game will be given his final score, the number of perfect jumps and the number of jumps he has performed and his game will be stored in the database.

\section{Sounds}

There is a set of sounds that are specific to Corda. We have created these to mimic children near the player, playing catch the rope. These allow for the gameplay to be more intense, as with their creation we aim to create the environment we describe our game to be in. We have done some investigation into how we could create the sound effect described earlier. After that, we had to alter the sounds through the sound effect and get the effect we wanted. Again, to do this, we used Audacity.

\subsection{Database}

In this section we will discuss how we have organized the databases used for each game, how communication is performed between each game and its database and what information is sent and stored. Also, we will explain how the information that is uploaded is organized.

\section{Rest Client for Unity}

Firebase was our choice because of the familiarity we have with it as we have used it in previous projects. Also, it offers a realtime database that allows for constant monitoring, specially useful during our study.

To communicate with Firebase we have the plugin Rest Client for Unity, as explained previously. This Plugin solved the solutions of not being able to communicate with Firebase as the Firebase SDK is not available for standalone Unity builds as our games. Additionally, the version 2019.3 of Unity, which we are currently using, has a bug which complicates the use of Firebase.

The Plugin Rest Client for Unity offers the default HTTP methods and it is based on HTTP Promises for a better assynchronous communication. A Promise is a proxy for a value not necessarily known when the promise is created. It allows to associate handlers with an asynchronous action's eventual success value or failure reason.

This lets asynchronous methods return values like synchronous methods: instead of immediately returning the final value, the asynchronous method returns a promise to supply the value at some point in the future. 
An attribute that stores the $u r l$ of the database is required for the plugin to work. This attribute is used by the functions we will describe next. Below we list the possible values for this attribute, each value corresponding to one of the databases:

1. Attribute databaseURL

- Data Gesture Database - https://detecao-de-gestos.firebaseio.com/

- Guarda Redes - https://guarda-redes-47856.firebaseio.com/

- Foguete - https://space-shooter-73f6f.firebaseio.com/

- Corda - https://saltarcorda-746c9.firebaseio.com/

User

We have created the class User to represent and store information about a participant. A User is uploaded to the database of gesture performance after recording the initial set of gestures. A User is composed by the following set of attributes: username, android version, device model, device name, screen height and screen width. Table 4.1 explains these attributes.

The first time a player plays our games we also upload their User information to the database respective of that game, where we also store the game sessions. The class User is marked as Serializable to be able to be serialized into a JSON. This process allows us to have the same participant represented in both databases and allow their games with their set of recorded gestures. Also, this ensures that when uploading a game session, this will always be matched with an existing participant.

\begin{tabular}{|l|l|l|}
\hline Attribute & Description & Example \\
\hline Username & $\begin{array}{l}\text { Participant's id and their device } \\
\text { model }\end{array}$ & "200-Sony H4113" \\
\hline Android Version & $\begin{array}{l}\text { The smartphone's operating sys- } \\
\text { tem }\end{array}$ & $\begin{array}{l}\text { "Android OS 9 / API-28 } \\
\text { (50.2.A.3.77/2122144346)" }\end{array}$ \\
\hline Device Model & Model of the device & "Sony H4113" \\
\hline Device Name & Name of the device & "Xperia XA2" \\
\hline Screen Height & Height of the device, in pixels & "1776" \\
\hline Screen Width & Width of the device, in pixels & "2180" \\
\hline
\end{tabular}

Table 4.1: User - Attributes and their description

\section{Game Session}

A Game Session represents a game played by a User. This Game Session is represented by the class Jogo. Like User, class Jogo is marked as Serializable to be able to be serialized into a $J S O N$. 
Game sessions are similar throughout the games, however with a few key differences. Each Jogo is composed by the following set of attributes: score, duration, timestamps for the beginning and end of the game, timestamp of opening the game, number of touches during the game, number of touches while navigating on the menus and username of the participant. Table 4.2 explains these attributes.

Additionally, each Jogo is composed of a set of attributes specific to each game: for Corda, a game session also stores the number of perfect jumps and the number of normal jumps; for Guarda Redes, a game session also stores the number of back-and-forth swipes, the number of L-shaped swipes, the number of normal swipes and the total number of swipes detected; finally, for Foguete a game session also contains the number of swipes detected and the number of enemies avoided.

\begin{tabular}{|c|c|c|}
\hline Attribute & Description & Example \\
\hline Username & $\begin{array}{l}\text { Participant's id and their } \\
\text { device model }\end{array}$ & "1-samsung SM-G950F" \\
\hline Open Game timestamp & $\begin{array}{l}\text { Timestamp of when the } \\
\text { game was opened }\end{array}$ & "05/01/2021 15:22:20" \\
\hline Start timestamp & $\begin{array}{l}\text { Timestamp of when the } \\
\text { participant started play- } \\
\text { ing a game }\end{array}$ & "05/01/2021 15:34:02" \\
\hline Gameover timestamp & $\begin{array}{l}\text { Timestamp for when the } \\
\text { participant lost }\end{array}$ & "Sony H4113" \\
\hline Touches on the menus & $\begin{array}{l}\text { Number of touches while } \\
\text { navigating on the menus }\end{array}$ & $" 10 "$ \\
\hline Touches on the game & $\begin{array}{l}\text { Number of touches while } \\
\text { playing }\end{array}$ & "10" \\
\hline Total Detected Swipes & $\begin{array}{l}\text { Total number of swipes } \\
\text { detected while playing }\end{array}$ & $" 10 "$ \\
\hline Total Swipes Simple & $\begin{array}{l}\text { Total number of sim- } \\
\text { ple swipes detected while } \\
\text { playing }\end{array}$ & $" 2 "$ \\
\hline Total Swipes Back-And-Forth & $\begin{array}{l}\text { Total number of back- } \\
\text { and-forth swipes detected } \\
\text { while playing }\end{array}$ & $" 4 "$ \\
\hline Total Swipes L-shaped & $\begin{array}{l}\text { Total number of back- } \\
\text { and-forth swipes detected } \\
\text { while playing }\end{array}$ & $" 4 "$ \\
\hline Score & Score of the game played & $" 1000 "$ \\
\hline Defenses & $\begin{array}{l}\text { Number of defenses } \\
\text { made }\end{array}$ & $" 10 "$ \\
\hline
\end{tabular}

Table 4.2: Game Session - Attributes and their description 


\section{Detection}

The gesture performance information gathered from participants is stored in a separate database. We have created the class Detecao is the class to represent this information. Class Detecao is also marked as Serializable to be able to be serialized into a JSON. Table 4.3 provides a description of the attributes of the class Detecao:

\begin{tabular}{|l|l|l|}
\hline Attribute & Description & Example \\
\hline Tipo & $\begin{array}{l}\text { Name of the detected ges- } \\
\text { tures }\end{array}$ & "Esquerda" \\
\hline List of coordinates & $\begin{array}{l}\text { List with the gesture's x } \\
\text { and y coordinates, in pix- } \\
\text { els }\end{array}$ & "[477.24609375, \\
$462.4765625] "$ \\
\hline List of timestamps & $\begin{array}{l}\text { List with each of the coor- } \\
\text { dinates' timestamps }\end{array}$ & $\begin{array}{l}\text { "[15:05:55150, } \\
15: 05: 55160]\end{array}$ \\
\hline Distance X & $\begin{array}{l}\text { Gesture's distance on the x } \\
\text { axis, in pixels }\end{array}$ & "250 px" \\
\hline Distance Y & $\begin{array}{l}\text { Gesture's distance on the y } \\
\text { axis, in pixels }\end{array}$ & "250 px" \\
\hline Difference between touches & $\begin{array}{l}\text { For double-taps, time be- } \\
\text { tween the two taps, in mil- } \\
\text { liseconds }\end{array}$ & "0.200 ms" \\
\hline Duration & $\begin{array}{l}\text { Gesture's duration, in mil- } \\
\text { liseconds }\end{array}$ & "0.800 ms" \\
\hline Velocity & $\begin{array}{l}\text { Gesture's velocity, in pix- } \\
\text { els/milliseconds }\end{array}$ & "2000 px/ms" \\
\hline Angle & \begin{tabular}{l} 
Gesture's angle, in degrees \\
\hline
\end{tabular} & "140 \\
\hline
\end{tabular}

Table 4.3: Detecao - Attributes and their description

\section{Database Organization}

As mentioned earlier, each game communicates with its own database where it is responsible for storing the game sessions players play of that game. Each each game also communicates with the database that stores the gesture performance information.

Each of the databases responsible for storing game sessions stores them under /jogos. Each database also stores the users playing that game and those are stored under /users. Finally, each database stores information regarding the tutorials, to understand whether players have had any difficulty in any of its parts. Storing this information allows us to understand the player's history in our games.

Regarding the game sessions, these are stored with the keyword Geral under jogos, like so: jogos/Geral. This applies to Foguete, Corda and Guarda Redes. However, as Guarda Redes offers two game modes, to differentiate between them, each is identified 
with a keyword, corresponding to the game mode: Geral for Normal mode and Defesas Laterais for Defesas Laterais mode.

So, if a player plays one game on Normal mode, this game will be stored under jogos/Geral. In addition, Guarda Redes offers a mode in which players can train a shot or set of shots. These are also stored on the database with the name of shot or shots they were practising. For instance, if the user was practising swipes up, then this game session will be stored under jogos/up.

Regarding the tutorial, for every part of it successfully performed by the players, a field Tutorial is sent to the database with the part they have completed marked as 1 . That field Tutorial is composed by the parts of the tutorial. This means that for game Corda, this field is composed of 5 parts, for Foguete it is composed by 6 parts and for Guarda Redes it is composed by 8 parts. Once the player completes the tutorials, the field Tutorial will be filled with the value 1 for every part of the tutorial. This means the player has successfully completed the tutorial. Should one of those values be different then one, we would be able to detect any problem and contact the player.

Finally, each gesture performance information for each game is stored under Sessaoname being name the game which the user has performed this. Conversely, one of three choices: Corda, Guarda Redes or Foguete. For game Corda gesture performance will be stored under Sessao-Corda, for game Guarda Redes will be stored under SessaoGuardaRedes and for game Foguete will stored under Sessao-Foguete. 


\section{Chapter 5}

\section{User Evaluation}

We conducted a remote user study with visually impaired users with different levels of expertise in handling their smartphones. Our goal was to understand whether the games we have developed have the potential to teach and train players about the gestures both necessary to play and to use on their daily smartphone usage, particularly for novice users. Also, we are trying to understand if by playing our games participants improve their general knowledge on what gestures are, on how to perform them, if they think their gesture performance has improved and if our games were seen as an educational tool. We contacted participants with a link for every game and ask them to play them throughout a week. We encouraged them to play in the order of the least complexity of gestures required. At the end of the study, participants took part in a remote debriefing interview of 20 minutes composed of open-ended questions about the participants' perspectives on the games, smartphone usage after playing and overall gesture learnability. The gestures we recorded were used to assess gesture performance before playing our games.

\subsection{Participants}

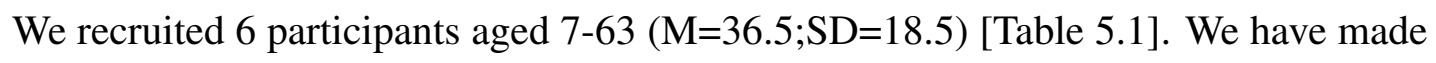
contacts with Fundação Raquel and Martin Sain and with Associação Promotora do Ensino dos Cegos (APEC) to gather interest in our study. We made an effort to recruit people with all levels of expertise, reaching both expert and novice users as well as people with different levels of gaming habits, from more dedicated gamers who play more than once a week to participants who play occasionally. 4 participants were totally blind (i.e. no light perception) and 2 participants (P5, P6) were near totally blind (i.e. visual acuity lower than 6/60).

Participants had to be 7 or older and minors could only participate with the authorization of their legal guardian. Participants should not have other kinds of severe impairments (mobility, hearing, cognitive), since games were not designed considering other disabilities. We compensated all participants who fulfilled the protocol with a $€ 5$ (or 
local currency equivalent) voucher, for their time.

\begin{tabular}{|c||c|c|c|c|}
\hline ID & Gender & Age & Playing Frequency & Smartphone Use \\
\hline \hline P1 & Male & 46 & A few times a week & 4 - Expert \\
\hline P2 & Male & 7 & A few times a week & 1 - Rookie \\
\hline P3 & Male & 21 & A few times a week & 5 - Expert \\
\hline P4 & Male & 63 & A few times a week & 4 - Expert \\
\hline P5 & Male & 49 & A few times a week & 4 - Expert \\
\hline P6 & Male & 33 & A few times a week & 4 - Expert \\
\hline
\end{tabular}

Table 5.1: Demographic Information and Gaming Frequency of participants

In addition, we encourage participants to share our games amongst family and friends and that resulted in having more players playing our games. However, these do not qualify as participants for our study as we did not contact them and they did not fulfill our initial questionnaire. Overall, we had 13 more players playing our games, although not all of them played all the games.

\subsection{Procedure}

After filling out the participation form, we asked participants to fulfill a demographics questionnaire that would also ask questions about their smartphone use and ability. The document containing the questionnaire is available: appendix $\mathrm{E}$. This questionnaire was build in Google Form and was tested for accessibility. Multiple-choice questions were mandatory but open-ended questions were optional. After that, participants were contacted via email with instructions and the link to download the games via Playstore. Before playing our games, participants were guided to record a set of gestures. Each set of gestures is related with the game that they will be playing for the following two weeks. Participants were asked to play the games for five days. After playing our games, participants took part in a audio-recorded remote interview of approximately 20 minutes in which we would delve into a conversation taking into consideration open-ended questions regarding their perspective on the games, their usage of their smartphone after playing our games and practising gestures. The interview document is available: appendix $\mathrm{D}$.

Game sessions of each participant were stored in a cloud database with secure authentication that only researchers have access, which was valuable to give us insight about the number of game sessions played and to distinguish the participants' experiences. To each participant will be assigned an ID.

Gesture Performance of each participant was also stored in a cloud database with secure authentication that only researchers have access, which was valuable to understand and compare their abilities before playing our games. Each of the gesture performance sessions is stored with an ID, allowing us to identify the participant as well. 


\subsection{Data Analysis}

We performed a deductive thematic analysis over all open-ended questions. Firstly, we familiarized with the data, by reading the answers iteratively. Even before we collected the responses from all participants, we started to annotate relevant phrases and recurring ideas in the text. We created a set of initial codes deductively informed by our readings and these were discussed among the authors, revised and added, as more responses were being submitted. We have done discussions in which themes were discussed, codes were aggregated, relationships were identified and discussed with examples (quotes) spread throughout the board that illustrated the themes. The final codebook and outline of the themes are available in appendices $\mathrm{H}$ and $\mathbb{I}$.

Using a mixed-method approach, we characterize the participants' experiences and perspectives on the games we developed. This characterization is primarily based on the thematic analysis of open ended questions and further reinforced with game session logs and their gesture performance data. We will delve into the gesture performance data first. We will present a set of tables, in which we will be displaying the number of total gestures versus the number of correct gestures, of those gestures performed.

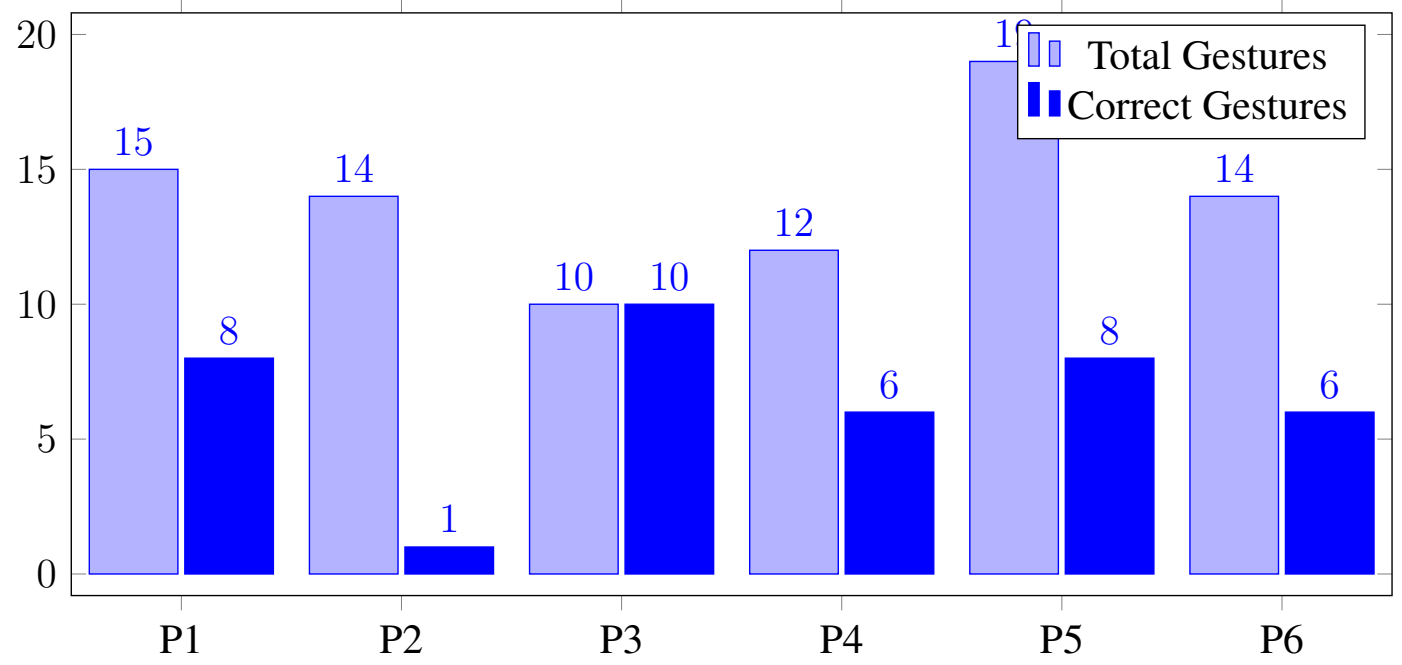

Figure 5.1: Gesture Performance - Total vs Correct (Corda)

Figure 5.1 illustrates the initial gesture performance of our participants in Corda. This initial phase asks for a smaller total number of gestures, 10. We can see that all participants apart from P3 performed more gestures than the required. On average, participants performed 14 gestures and on average (S.D=2.7), 7 of those were correct $(\mathrm{SD}=2.8)$. This average of correct gesture tends is very low due to the fact that $\mathrm{P} 2$ only performed 1 gesture correctly, out of 14 performed. This means that participants performed $50 \%$ of the gestures asked correctly. 


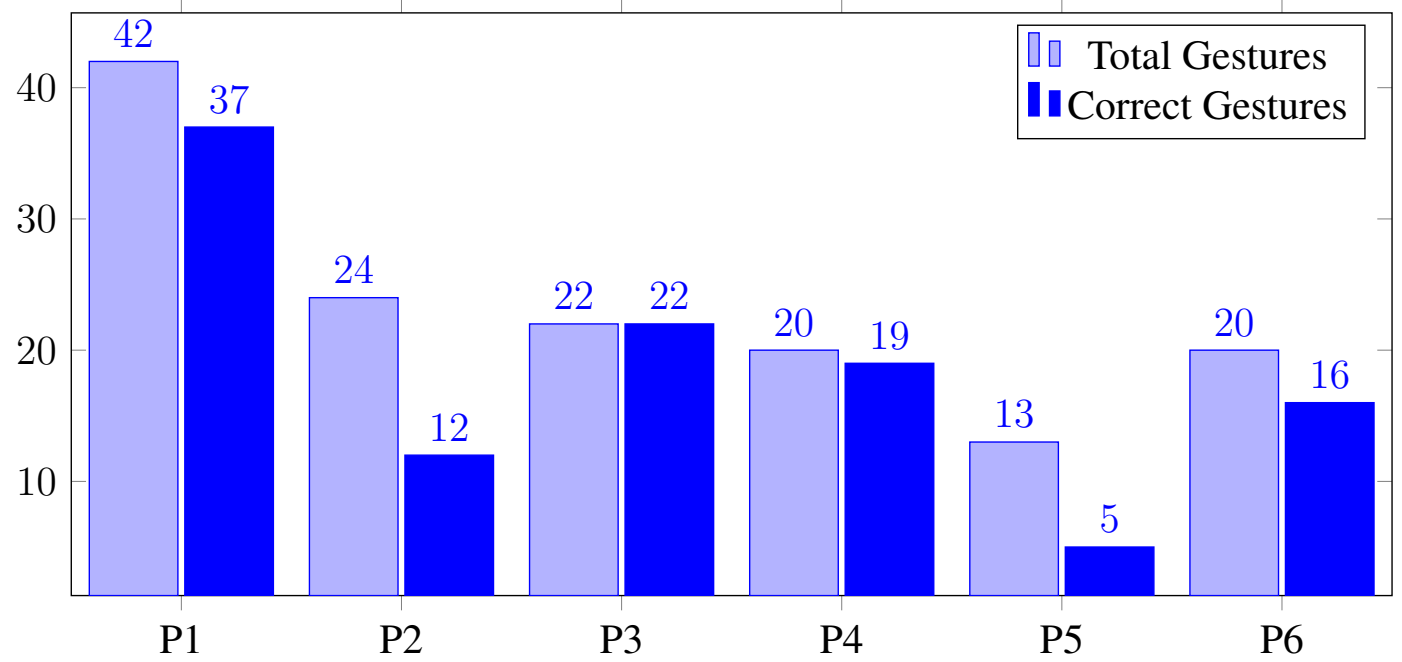

Figure 5.2: Gesture Performance - Total Gestures vs Correct Gestures (Foguete)

Figure 5.2 illustrates the initial gesture performance of our participants in Foguete. This initial phase asks for total number of gestures of 20. However, we were only able to record a total of 13 gestures from P5. On average, participants performed 24 gestures $(\mathrm{SD}=8.9)$ and $18(\mathrm{SD}=9.8)$ of those were correct, on average. This means that participants performed $78 \%$ of the gestures asked correctly.

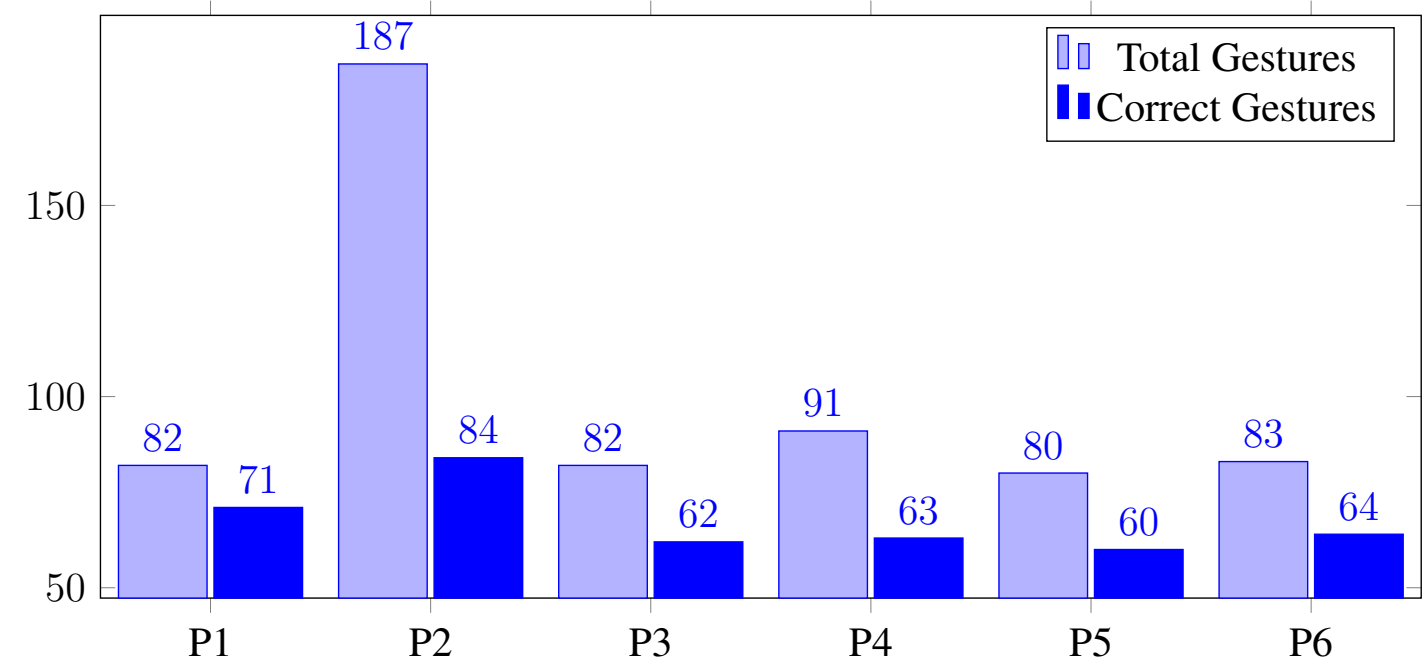

Figure 5.3: Gesture Performance - Total Gestures vs Correct Gestures (Guarda Redes)

Figure 5.3 illustrates the initial gesture performance of our participants in Guarda Redes. This initial phase asks for 80 gestures total. Right away, we can notice that participant P2 performed an amount of gestures much higher than what he was required to and so, this will affect the following results. On average, participants performed 100 gestures $(\mathrm{SD}=38.7)$ and 68 of those were correct $(\mathrm{SD}=8.1)$. This means that participants performed $68 \%$ of the gestures correctly. 


\subsection{Findings}

\begin{tabular}{|c||c|c|c|}
\hline ID & Corda & Foguete & Guarda Redes \\
\hline \hline P1 & $15(24)$ & $11(14)$ & $3(49)$ \\
\hline P2 & $78(31)$ & $30(14)$ & $103(43)$ \\
\hline P3 & $4(45)$ & $37(14)$ & $11(55)$ \\
\hline P4 & $13(32)$ & $62(12)$ & $25(54)$ \\
\hline P5 & $17(15)$ & $40(13)$ & $47(41)$ \\
\hline P6 & $4(42)$ & $7(12)$ & $4(91)$ \\
\hline
\end{tabular}

Table 5.2: Play session time details. Playtime for each game rounded to seconds.

Individual information about each participant's game sessions are shown in Table 5.2 . Game sessions for Corda lasted for an average of 32 seconds ( $\mathrm{SD}=10.1$ ), game sessions for Foguete lasted for an average of 13 seconds $(\mathrm{SD}=0.9)$ and for Guarda Redes, game sessions lasted for an average of 56 seconds $(\mathrm{SD}=16.6)$. This information goes alongside with what our goals were for our games, to be played multiple times over short sessions.

\subsubsection{Exclusion from Playing}

Accessible technologies, such as screen-readers like Google Talkback, do not offer accessibility to the full extent. As visually impaired people become more proficient with it, they start to understand how this could be improved and the advantages of other accessible tools compared to Google Talkback, in terms of development and functionality:

"Do you know that I don't use Talkback now? I use another program that is out there that is Jisu. Talkback is rusting, it's very slow." - P5

"Yes, Jisu, its interaction is much faster, it has nothing to do, nothing, nothing at all." - P5

Participants also highlighted the need for more accessibility options or games, as the available do not fulfill their needs: there are very few gaming options, not many accessible games available and the ones that are, often are not fully developed in terms of accessibility options. More in particular, P2 mentions that for his son there is a lack of accessibility tools and games that captivate him enough to improve, in terms of smartphone usage and overall dexterity:

"I reached the conclusion that there were no applications or games that excited him to the point of using it as a tool with support for the blind." - P2

"Because even in the play store, there are not many accessible games.." - P3 
"I really wish the games didn't stop there, there really aren't that many games for us to interact with." - P5

\subsubsection{Gesture Learning and Perception}

Participants explained how intuitive Google Talkback gestures felt to them and were able to elaborate on methods used to learn those gestures, being the tutorial provided by Talkback, mailing lists, assistance from peers and exploration. In addition, participants highlighted how important it is for inexperienced or less experienced visually impaired people to explore the gestures on their own, as without doing this the methods mentioned above may be less effective:

"I learned to use them by using Talkback. I was learning as I was using the screen reader.” - $\mathrm{P} 2$

"The best way can learn is by using the Talkback manual and by training. When I don't know, I have to ask for help. And then exploring, because telling him "look, do it like this" but if you don't have your phone by your side, the person has to explore and try to understand how it works." - P4

"Most of the gestures I learned were alone, asking friends, through a list that exists on the internet for Android that, from time to time.." - P3

Participants were familiarized with the gestures our games have, as these were the gestures used to navigate with Google Talkback. In addition, participants' familiarization is demonstrated as gestures and their actions are mentioned in multiple occasions, relating these gestures with the gestures of our games.

"The gestures are practically all in Talkback, these gestures from the games." - P5

"Yes, the gestures I knew, the gestures that you applied in your games." - P4

From the gestures Google Talkback has, participants explained the most difficult are back-and-forth gestures and some angle-gestures, as these require movements that are not so common, are less intuitive than the more simple gestures and their function typically is not used:

"For example, when you slide your finger to bottom and to the right, without removing your finger from the screen." - P2

"For example, going backwards, which is a drag from top to bottom and to the left, is much faster than going in search of the backward button, although I already know where it is..” - P5 


\subsubsection{Discovery Through Entertainment}

All participants reported a positive experience with at least one of our games, considering all of them to be engaging. Two of our participants considered Guarda Redes as their favourite, mentioning that multiple times, as it was the most interesting and the most engaging for them.

"His favorite game is Guarda Redes. (...) It is the closest, it has the sounds similar to being in a stadium, the goal, the defense, which excites him." - P3

"The game I play the most is Guarda Redes. It's what draws my attention the most." - $P 5$

Participants also highlighted the complexity of the games and explain how they perceived that complexity. The overall feeling was that Corda was a simple game, as P4 states "Corda is the simplest, it just requires those two touches, ready." and has P3 mentions "Corda game was the easiest to explain to him, how it worked because it didn't have so many inputs, it was easier to understand.".

Guarda Redes was perceived as complex because it has the most complex gestures and participants had a hard time distinguishing types of shots, as P1 states "When the shots are up right or left the sound is confusing, I cannot understand.." and $\mathrm{P} 2$ also states "Sounds that are more complex, top, bottom or center, are not very clear to him..", although it was the most interesting as the idea behind the game highly captivated participants.

Foguete was considered the most complex and the most confusing game, as it depends on binaural sound and multiple simultaneous audio effects. P3 mentions "Foguete is a big confusion of sounds (..) I never really know where the enemies comes from”, P2 shares the same opinion "I think Foguete ends up being a bit confusing, it has too much sounds.." and P5 mentions how hard it is to get a higher score as it appeared more confusing - "Now, Rocket, we have to do left, right, not hit the asteroids and I never really exceeded 1000 points..”.

Participants were also keen on making suggestions on how the game could be improved, in terms of gameplay and game organization. Regarding gameplay, P3 suggested introducing levels of difficulty in Guarda Redes and including visual animation on Corda, like in Foguete and Guarda Redes, as he felt this would increase the inclusion experience of the game:

"(...) Like in Rocket, on Guarda Redes perhaps introducing levels where more time is allowed." - P3

"In Corda, if it were possible to introduce an animation similar to that of Foguete, so that you can play with the friends you give the phone to, pass a level, pass to a friend and while he plays with the sound, the friend will play visually..” - P3 
In terms of game organization, P1 suggests the explanation of the gestures to be highlighted on the main menu - "The only thing I would try to improve in the three games would be to put the explanation of the gestures in the menu..”. P4 suggested for us to include the tutorial as an extra option of instructions, as he felt that it teaches key aspects and if a player does not play the game for a while, the player should have the chance to do it again - "If I want to go back to the beginning, I'm not playing for a week or two, I'm going to play but I don't remember what to do anymore. I can't see this start-up manual, can I?".

Also, participants mentioned they would like to actually use Talkback or other screen readers during the game, as they are used to another type of navigation and other types of preferences on their screen readers, mainly the speed:

"I would like for it to have a feature that could make the voice faster or slower.." - P4

"Because usually I'm in an application, we can slide to the side or two fingers up when there's a lot of objects, the page goes up, you should do the same..” - P5

Participants highlighted the fact that our games were entertaining and that entertainment factor is a positive influence on gesture practice, as players feel motivated to play and learn more, specially for lower age groups:

"So, at the telephone level, exploration through gestures, the games I noticed were an asset in the sense of exploring gestures.." - P3

"Of course, for beginners it is interesting to have a game to get used to performing gestures.." - P4

"I can see that when he's paying attention, he's trying to make the movement and then sometimes it works and sometimes it doesn't. This is what interests me, is that he tries to make the movement." - P3

\subsubsection{Gesture Practice and Discovery}

Participants highlighted that games were an interesting method for gesture discovery as an introduction for less experienced users, both to Talkback gestures and accessibility in general:

"For those who are at the beginning, they will enter at the very beginning, it really is a good way to train the gestures. (...) For those who have not interacted with accessibility the experience is perfect." - P5

"I think it is a good way to introduce not only for those who are already used but mainly for users with little experience, they will learn much faster if they are in a game 
than listening to that boring Talkback tutorial." - P1

Participants also mentioned that what more experienced users search in game is their gameplay and are looking play them, not to use them as method for training or gesture discovery. However, P2 mentioned that even experienced users could learn from the games as well - "Users, even the most experienced, end up learning something.":

"Therefore, at the level of experienced people the interest of the game will be to play, at least for me. In my opinion it is playing because I haven't learned anything new from here.." - P4

"Now, for those who are already more advanced, gestures are already so internalized, (...) it's already intuitive. You don't have to think too much about it.” - P5

P2 highlighted how playing and discovering gestures would lead to autonomy, as he aims to introduce his son to more technologies and platforms, independently of their level of accessibility and he feels this has a positive result in terms of his autonomy:

"Above all, I try to make him integrate with these technologies. On Playstation (...) There are games that he plays autonomously, he can enjoy the sound of cars, motorcycles, changing weapons, shots and can be autonomous in it." - P2

"(...) he is trying to make the movement, sometimes it works and sometimes it doesn't. This is what interests me, is that he tries to make the movement." - P2

This autonomy is demonstrated by both the growth of his son is terms of gesture performance but as well as his son keeps on asking to play the games more and manifests a keen interest on them, as our games proved engaging to them, as we have mentioned earlier:

"He is already autonomous in the games, he goes to the options he wants. (...) He already knew how to navigate the phone, with Talkback. And now with the applications, as I was just saying, he is already autonomous.." - P2

"And the fact that he asks me at the end of the day, after school tasks, dinner, "Dad, can I go over the phone for a while?" and asks to play the three games, makes me happy." - P2 


\subsection{Limitations}

We conducted a fully remote study due to the pandemic context we currently live in and so, we could not control aspects such as the Internet connection of participants, devices they used to play, time played, etc. Therefore, a bug in any of our games could happen and we had to adjust accordingly. Unfortunately that happened, as one of our participants initially was not able to take part in our study as we worked to solve this problem.

Additionally, to upload game sessions or gesture performance data we had to secure an Internet connection. If participants were playing our games without any connection, their data would not be uploaded.

Although the primary target of our games are newcomers and novice smartphone users, we were only able to recruit one participant at that stage. Due to the pandemic we were not able to do conduct co-located sessions which make it impossible to onboard newcomers and novice (e.g. guide people installing our games). Instead, we relied on more knowledgeable users experience and feedback to access the potential of our games as discovery and training tools.

\subsection{Discussion}

This experience was seen by our participants as a chance to play more accessible games and this was manifested as there is a lack of accessible games for smartphone. This experience was enjoyable as participants showed interest in the games developed and were keen on understanding if more games were developed and on making suggestions on how these games could be improved. In our study, the possibility of using games as a method for practising and discovering gestures was highlighted, as participants understood how the games aimed to teach those gestures and recognized how these can be valuable, particularly for less experienced players. We collected valuable feedback from the participants' perceptions we consider to be informative for research in gaming and accessibility, both in terms of game development and how the development of accessible games could be improved but also on how games have an educational potential, not explored in too deep according to our research done previously.

\subsubsection{Learning Process}

The research we have done showed that the development of accessible games has been increasing and the number of accessible games for visually impaired people to play has been increasing as well. In that research we presented several examples of accessible games, for computers and smartphones. However, the fact is that some are not fully accessible or do not have their accessibility options developed to full extent and so, visually 
impaired players struggle to find games to play. Our results go in accordance to this, as our participants explained to us how hard it still is to find accessible games, mainly for smartphone and the desire for accessible games is there, even for players who do not play that often.

As accessible technologies like Google Talkback keep on developing and improving, the general feeling is that improvement is not enough, which forces some visually impaired users to search for better fitting alternatives, in this case, a better fitting screenreader. However, this search is limited by the fact that it might require an extra expense, often not considered a possibility which results in less alternatives. This lack of improvement also has a negative effect on the learning process of those technologies, as it is considered to be very slow and very dependent on the few materials available, such as Google Talkback's tutorial and on other types of help such as assistance from peers, heavily dependent on mailing lists and hands-on assistance.

For less experienced visually impaired users, their process of learning gestures and smartphone navigation tends to be more difficult, firstly because they may not be aware of methods such as mailing lists and may not be able to get a more hands-on help and secondly because there are not many playful methods for learning, particularly playful accessible games, with which would result in a much more intuitive process of learning. The results from our study suggest the scarcity of accessible games for young visually impaired players.

\subsubsection{Potential of Playing and Learning}

The research we performed about learning through gaming allowed us to understand how educational games could be used as an effective tool to make players learn through playing them. This is achieved through engaging games, which motivate the players to spend time on a task and on perfecting it, using techniques such as sonification and corrective verbal feedback. Our results suggested that the games we developed were engaging and could take a key role as their potential for being a method of practise and discovery of smartphone gestures was recognized, as these included the gestures usually most used to navigate the smartphone.

Our results also suggest that these games could have a positive effect on the the process of learning gestures for visually impaired, particularly for novice users. In addition, our games were found playful and it was recognized that there is a lack of such accessible games, generating interest in understanding if more games were developed.

However, our results also demonstrated that our games were not able to clarify and explain enough the relationship between the gestures that are being practised on the games and their function on Google Talkback, what happens when they are performed, thus having only an effect on the general knowledge about its navigation and not their concrete function. 
Finally, our results suggest that our games had a positive effect on the learning process and that this aspect would lead to better personal development in terms of usage of accessible tools, increasing the level of autonomy of the players, as we explain on our findings. This, on consequence, is related with aspects such as social inclusion, as visually impaired users are able to become more autonomous with not only this tool but also with others and are able to interact more easily with sighted and non-sighted users as a result of their growth in usage of accessibility tools. 


\section{Chapter 6}

\section{Conclusion}

Video games have spread across multiple platforms and devices, like computers, mobile phones and others. However, accessibility options is still a key issue missing on their development. Although the development of accessibility options has been increasing over the years, the fact is that video games are not fully accessible and for people with visual impairments, this means they cannot get the same experience as sighted individuals do, at least not fully. Despite this, over the last few years the attention to accessibility options has been increasing and examples of video games development of this have been surging.

We took a closer look into the development of accessible games and were able to develop a set of three accessible games, Games for Gestures, that focus on the set of gestures the screen-reader Google Talkback has to offer and are based on the guidelines for the development of accessible games we researched, which highlight techniques such as sonification but also factors of the game's gameplay, such as a system of bonus to reward players.

We performed a study to understand how the process of learning gestures for smartphones occurs and to understand if and how accessible game could have an impact on that process. We approached 6 visually impaired users, with different levels of expertise and our results suggest that there is a lack of accessible content, particularly accessible games and there is a great interest both on the content we developed but also on getting new content, new games. We encouraged participants to share our games and that had an impact as well, as we have noticed more players playing our games with positive feedback.

Participants highlighted how our games were able to replicate the gestures of Google Talkback and that this would be a positive aspect in terms of improving general knowledge about the gestures. Participants also highlighted how our games had the potential of being another teaching method, in a more playful way as their gameplay was interesting and they found the games enjoyable. Our results suggest that accessible games can positively impact the process of learning gestures, particularly for younger less experienced users, as the methods for learning gestures are not playful enough, and a playful experience can have a better impact on that process. 
Our results also allowed us to understand the impact of accessible games on this process. It can lead to situations in which autonomy of the players is could be achieved faster, highlighted by the multiple contributions our participants made and that growth in autonomy could improve social inclusion, as visually impaired users will be able to understand the accessibility tools on their disposal in a timely manner and will be able to understand the advantages of one versus another.

\subsection{Future Work}

After completing this thesis, there are aspects that can be improved or added in the future so that the application becomes richer and more complete. These were based on the feedback we obtained during out study, as we felt it would be interesting to get insightful thoughts about how our games could be improved:

- Introduction of levels of difficulty: similar to how tutorial is organized, the introduction of levels associated to components of the game would be an easier way to present game features, particularly for Guarda Redes and Foguete, as participants felt the games were a bit complicated in terms of features and sounds;

- Visual animation: Corda does not have a visual animation alongside the gameplay. The creation of this visual element would allow for the game to be more inclusive, as sighted and non-sighted players would be able to either play or view others playing, visually or audibly;

- Tutorial being available: the tutorial is only available to the participants one time, after they perform the set of gestures we ask them to. One of the feedback we got was that for players who would not play for some days, the tutorial would be important to remember the game's features;

- Description of visual elements: participants felt that despite having a tutorial describing each key feature and visual element of the game, there could be a better explanation of the visual elements we have present in Foguete and Guarda Redes, particularly the ships and the football field that is the background of the second. Alongside the background sound we display to create the environment, this would increase the gameplay and feeling of the games;

- Better explanation of Google Talkback gestures: our games had the ability to explain players the corresponding action of the gestures they were performing on Google Talkback. This was one of the key aspects. However, participants did not feel this was well explained enough, as it was hidden on the menus of the games. Locating this element better on our games would result in a much clearer way of displaying this key element. 
These aspects can also be applied on the development of future accessible games, in a more general way. Accessible games could come installed on the smartphones by default, as our results have illustrated the potential they have for being a good method for training and discovering gestures. These could teach the gestures in a progressive way, starting with a simple gesture, associated to a game mechanic and advancing to a more complicated gesture every time the previous gesture is understood.

In addition, the same process of learning gestures could also be applied to patterns, such as the pattern for making a phone call or sending an email or text. These patterns are widely used and so, they could also be applied to a game. Moreover, there are other examples of interactions we do not explore in the context of this thesis, such as the interaction with a list, which could be made into a game, as lists are one important component visually impaired users have to interact. 


\section{Appendix A}

\section{Corda Tutorial Script}

\section{Tutorial - Part 1}

After recording the set of gestures, the player will be instructed to enter the tutorial. In this phase, the player is instructed to perform a tap on the screen. This is the first instruction the player will hear:

"Vamos saltar à corda! Para obteres a melhor pontuação terás de saltar no melhor momento. A corda não vai parar, vamos ver quanto tempo aguentas. Primeiro vamos ver como podes saltar. Um toque no ecrã significa que estás a levantar uma perna. Para isso, deves tocar uma vez no ecrã: experimenta."

If the player does not perform the gesture asked, one of two messages is played: one if the player has not touched the screen and the other if the player has performed another gesture, like a long-press or a swipe. In either case, the player will repeat this phase of the tutorial.

"Não tocaste no ecrã. Se não saltares irás tropeçar na corda. Vamos tentar novamente. Para levantar uma perna deves tocar uma vez no ecrã: experimenta."

"Fizeste um toque muito longo no ecrã. Deves fazer um toque mais curto. Vamos tentar novamente. Para levantar uma perna deves tocar uma vez no ecrã: experimenta."

\section{Tutorial - Part 2}

The player has followed the instruction successfully and has advanced to the second part of the tutorial. In this phase, the player is instructed to perform a double-tap on the screen. The player will hear the following:

"Quando tocas apenas uma vez no ecrã vais tropeçar na corda e terás de começar o jogo de novo. O mesmo acontece se não tocares no ecrã. Agora, para saltares tens de fazer dois toques rápidos seguidos no ecrã. Ou seja um duplo toque. Experimenta."

If the player does not perform the gesture asked, one of two messages is played. one if the player has performed a double-tap with any of its touches being considered a longpress and the other if the player has only touched only or has not touched the screen at all. In either case, the player will repeat this phase of the tutorial. 
"Um dos teus toques foi muito longo. Para fazeres um duplo-toque, ambos têm de ser mais curtos. Vamos tentar de novo, experimenta."

"Não fizeste um duplo toque no ecrã. Para saltares tens de fazer um duplo toque no ecrã. Experimenta."

\section{Tutorial - Part 3}

The player has followed the instruction successfully and has advanced to the third part of the tutorial. In this phase, the player is instructed to perform a faster double-tap on the screen. The player will hear the following:

"Boa, conseguiste saltar. Saltar de forma perfeita garante mais pontos. Para isso tens de fazer um duplo toque mais rápido. Ouve o exemplo e de seguida experimenta."

If the player does not perform the gesture asked then will repeat the tutorial and hear the following message:

"Não fizeste um duplo toque no ecrã. Para saltares tens de fazer um duplo toque no ecrã. Experimenta."

\section{Tutorial - Part 4}

The player has followed the instruction successfully and has advanced to the fourth part of the tutorial. In this phase, the player is instructed to jump multiple times. The player will hear the following:

"Para saltares no momento certo, deves prestar atenção ao som da corda e tentar fazer um salto perfeito. A corda vai estar a bater e vou-te pedir para fazeres três saltos perfeitos. Não te esqueças, se não saltares perdes."

If the player does not perform the gesture asked then will repeat the tutorial and hear the following message:

"Falhaste o salto. Deves prestar atenção ao som da corda e tentar fazer um salto perfeito. A corda vai estar a bater, experimenta saltar algumas vezes."

\section{Tutorial - Part 5}

After successfully passing this phase of the tutorial the player reaches the last step. After this, he will be presented with the game's main menu and will hear the message:

"Quando começares a jogar, escolhes quando saltar da primeira vez e a partir daí, a corda não irá parar. Cada vez que não saltares irás recomeçar. Ao fim de três tentativas, o teu jogo irá terminar. Boa sorte."

\section{Shorter error message}

If the player fails to perform the gesture for more than one time in any phase, then a shorter message is played. That message is the following:

"Falhaste o salto. Vamos tentar novamente." 


\section{Appendix B}

\section{Foguete Tutorial Script}

\section{Tutorial - Part 1}

After recording the set of gestures, the player will be instructed to enter the tutorial. In this phase, the player is instructed to perform a swipe to dodge an enemy. This is the first instruction the player will hear:

"Estás numa nave espacial e o teu objectivo é desviares-te dos inimigos ou asteroides que virão contra ti. O ecrã está dividido em três zonas: esquerda, centro e direita. Este é o som de um inimigo que vem da zona da esquerda. Este é o som de um inimigo que vem da zona do centro. E este é o som de um inimigo que vem da zona da direita. Todos os inimigos ou asteroides poderão aparecer de qualquer uma das três zonas. Quando varreres o ecrã para a direita, vais para a direita. Quando varreres o ecrã para a esquerda vais para a esquerda. A tua nave começa o jogo no meio do ecrã, ou seja, na zona do centro. Quando ouvires o som do inimigo no centro, tens de varrer o ecrã para um dos lados para te desviares.

If the player does not perform the gesture asked then will repeat this part of the tutorial and will be presented with the following message:

"O som que ouviste foi o de uma explosão. É o que som que vais ouvir quando bateres nos inimigos ou nos asteroides. Vamos tentar novamente. Quando ouvires o som do inimigo no meio, tens de varrer o ecrã para um dos lados para te desviares."

\section{Tutorial - Part 2}

The player has followed the instruction successfully and has advanced to the second part of the tutorial. In this phase, the player is instructed to perform a swipe in the same direction as the previous. And so, the player will hear the following:

"Estás na zona da esquerda e não é possível ires para a esquerda novamente. Se tentares, irás ouvir um som como se batesses numa parede. Experimenta varrer o ecrã para a esquerda."

If the player does not perform the gesture asked then will repeat this part of the tutorial and will hear one of the following messages: 
"Estás na zona da esquerda e não é possível ires para a esquerda novamente. Se tentares, irás ouvir um som como se batesses numa parede. Experimenta varrer o ecrã para a esquerda."

"Estás na zona da direita e não é possível ires para a direita novamente. Se tentares, irás ouvir um som como se batesses numa parede. Experimenta varrer o ecrã para a direita."

\section{Tutorial - Part 3}

The player has followed the instruction successfully and has advanced to the third part of the tutorial. In this phase, the player is instructed to perform a swipe to dodge an enemy. The player will hear the following:

"Continuas na zona da esquerda e vem um inimigo contra ti. Desvia-te varrendo o ecrã para a direita."

If the player does not perform the gesture asked then will repeat the tutorial and hear one of the following messages:

"Um inimigo acertou em ti, por isso explodiste. Vamos tentar novamente. Continuas na zona da esquerda e vem um inimigo contra ti. Desvia-te varrendo o ecrã para a direita."

"Um inimigo acertou em ti, por isso explodiste. Vamos tentar novamente. Continuas na zona da direita e vem um inimigo contra ti. Desvia-te varrendo o ecrã para a esquerda."

\section{Tutorial - Part 4}

The player has followed the instruction successfully and has advanced to the fourth part of the tutorial. In this phase, the player is instructed to perform a swipe to dodge an asteroid. The player will hear the following:

"Agora, estás novamente na zona do centro e à tua frente encontra-se um asteroide. Desvia-te varrendo o ecrã para um dos lados."

If the player does not perform the gesture asked then will repeat the tutorial and hear the following message:

"O asteróide acertou em ti, por isso explodiste. Vamos tentar novamente. Desvia-te varrendo o ecrã para um dos lados."

\section{Tutorial - Part 5}

The player has followed the instruction successfully and has advanced to the fifth part of the tutorial. In this part, the player is instructed to perform a swipe to catch bonus points. The player will hear the following:

"Enquanto estiveres a jogar, podes apanhar o bónus para ganhar mais pontos. Quando ouvires o som do bónus, tens de varrer o ecrã para o lado de onde estás a ouvir o bónus. 
Depois de bateres no bónus, irás ouvir um som que significa que recebeste os pontos bónus.”

\section{Tutorial - Part 6}

After successfully passing this phase of the tutorial, the player is presented with the last step. After this step, he will be presented with the game's main menu. The player will hear the following:

"Chegámos ao final do tutorial. Durante o jogo tens 3 vidas, tenta sobreviver ao máximo de inimigos possível. Podes fazer o tutorial novamente, se quiseres. Boa sorte."

\section{Shorter error message}

If the player fails to perform the gesture for more than one time in any phase, then a shorter message is played. That message is the following:

"Vamos tentar novamente." 


\section{Appendix C}

\section{Guarda Redes Tutorial Script}

\section{Tutorial - Part 1}

After recording the set of gestures, the player will be instructed to enter the tutorial. In this phase, the player is instructed to perform a swipe to the right to defend a shot. This is the first instruction the player will hear:

"És o guarda redes da tua equipa e vais ter de defender vários remates. Vamos ver quantos consegues defender. Os remates podem ser para a tua esquerda, para a tua direita, para cima, para baixo ou para um dos quatro cantos do ecrã. Em cada jogo, começas no centro da baliza e sempre que sofreres um golo ou fizeres uma defesa, voltas para o centro para defender o próximo remate. Antes dos remates irás ouvir um apito. Depois irás ouvir os remates. Se não defenderes corretamente a bola bater num dos póstes da baliza e irás ouvir este som. Vamos a isto. Estás no centro da baliza e quando ouvires o apito vão começar a rematar para ti. Deves varrer o ecrã para o lado de onde ouves a bola. O próximo remate vem para a tua direita, experimenta. "

If the player does not perform the gesture asked then will repeat this part of the tutorial and will be presented with the following message:

"Sofreste golo. Vamos tentar novamente. Depois do remate, deves varrer o ecrã para o lado de onde ouves a bola. O próximo remate vem para a tua direita, experimenta."

\section{Tutorial - Part 2}

The player has followed the instruction successfully and so, has advanced to the second part of the tutorial. In this phase, the player is instructed to perform a swipe left. And so, the player will hear the following:

"Bom trabalho. Depois de defenderes voltas para o meio da baliza para defender o próximo remate. Tens de prestar atenção ao remate. Rápido, o próximo remate vem para a tua esquerda."

If the player does not perform the gesture asked then will repeat this part of the tutorial and will hear the following message:

"Sofreste golo. Vamos tentar novamente. Deves varrer o ecrã para o lado de onde 
ouves a bola. O próximo remate vem para a tua esquerda, experimenta."

\section{Tutorial - Part 3}

The player has followed the instruction successfully and so, has advanced to the third part of the tutorial. In this phase, the player is instructed to perform a swipe down. The player will hear the following:

"Bom trabalho. Os remates também podem ser feitos para baixo, para o meio das tuas pernas. O próximo remate será para baixo e terás de varrer o ecrã para baixo. Experimenta."

If the player does not perform the gesture asked then will repeat the tutorial and hear the following message:

"Sofreste golo. Vamos tentar novamente. Deves varrer o ecrã para o lado de onde ouves a bola. O próximo remate vem para baixo, experimenta."

\section{Tutorial - Part 4}

The player has followed the instruction successfully and so, has advanced to the fourth part of the tutorial. In this phase, the player is instructed to perform a swipe up. The player will hear the following:

"Bom trabalho. Os remates também podem ser feitos para cima da tua cabeça. $O$ próximo remate será para cima e terás de varrer o ecrã para cima. Experimenta."

If the player does not perform the gesture asked then will repeat the tutorial and hear the following message:

"Sofreste golo. Vamos tentar novamente. Deves varrer o ecrã para o lado de onde ouves a bola. O próximo remate vem para cima, experimenta."

\section{Tutorial - Part 5}

The player has followed the instruction successfully and so, has advanced to the fifth part of the tutorial. In this part, the player is instructed to perform an L-shaped swipe up then right. The player will hear the following:

"Bom trabalho. Os remates também podem ir para os cantos do ecrãa, os cantos da tua baliza. Para os defenderes, tens de varrer o ecrã em forma de L, sem largar o dedo para de onde ouviste o remate. O próximo remate vem para o canto superior direito. Tens de varrer o ecrã para cima e depois para a direita, sem tirares o dedo do ecrã. Experimenta."

If the player does not perform the gesture asked then will repeat the tutorial and hear the following message:

"Sofreste golo. Vamos tentar novamente. Deves varrer o ecrã para o lado de onde ouves a bola. O próximo remate vem para o canto superior direito, experimenta." 


\section{Tutorial - Part 6}

The player has followed the instruction successfully and so, has advanced to the fifth part of the tutorial. In this part, the player is instructed to perform a back-and-forth swipe left then right. The player will hear the following:

"Bom trabalho. Através da opção Treinar Remates podes treinar qualquer tipo de remate. Quando selecionares um ou vários irás ouvir uma pequena explicação de como deves defender. No menu inicial tens os modos de jogo: o modo jogo aleatório e o modo defesas laterais. Quando selecionares um dos modos ouves uma pequena explicação de como deves jogar. Vamos experimentar agora o modo Defesas Laterais. Irás ouvir dois remates, um à esquerda e um à direita. Depois de os ouvires, tens de varrer o ecrã primeiro para a esquerda e depois para a direita para os defenderes, sem tirar o dedo do ecrã. O guarda-redes só se irá mexer quando tirares o dedo do ecrã. Experimenta!”

If the player does not perform the gesture asked then will repeat the tutorial and hear the following message:

"Sofreste golo. Vamos tentar novamente. Deves varrer o ecrã para o lado de onde ouves a bola. O próximo remate vem para o canto superior direito, experimenta."

\section{Tutorial - Part 7}

After successfully passing this phase of the tutorial, the player is presented with the last step. After this step, he will be presented with the game's main menu. The player will hear the following:

"Bom trabalho. Conseguiste defender os dois remates. Chegámos ao final do tutorial. Durante qualquer modo de jogo só podes deixar entrar 5 golos. Boa sorte."

\section{Shorter error message}

If the player fails to perform the gesture for more than one time in any phase, then a shorter message is played. That message is the following:

"Sofreste golo. Vamos tentar novamente." 


\section{Appendix D}

\section{Interview Script}

1. How did you become familiar with the different gestures you use to interact with your smartphone?

(a) Were they easy to learn?

(b) Easy to discover?

2. How do you think it would be the best way for a new user to learn how to use a smartphone?

3. What did you think about the games?

(a) Did you find them engaging?

(b) Did you learn anything?

i. Did you know all the gestures the game's asked you to perform?

4. Did you feel you were performing the gestures the same you do when you are using your smartphone?

5. What are your thoughts in using games as a method for practising and discovering smartphone gestures?
(a) For experienced users?
(b) For newcomers/novice?

6. What would you change?

7. Would you recommend any of the games to your friends? 


\section{Appendix E}

\section{Demographics Questionnaire Script}

Hello! Again, thank you very much for your interest! This study is motivated to investigate how Android smartphone games can be used as a training and gesture learning method, namely the set of gestures that the Google Talkback screen reader offers. Through this form, I will ask you to share a little of your experience with gestures and games on your smartphone.

Your answer is completely voluntary and all data relating to you will remain anonymous. If you would like to know details of the results and implications of the study, we will send you a copy of the study report. If you have any questions about any aspect of this study, you can contact me by email, davidslycooper@hotmail.com.

1. Before proceeding, I ask you to confirm that you understand the terms of participation in this study.

2. Enter your email address.

3. I would like a copy of the study report to be sent to me by email.

4. How old are you?

5. Gender:

- Male

- Female

- Prefer not to say

6. How long have you been using smartphones?

- Less than 3 months

- Less than a year

- Less than 3 years

- More than 3 years

7. How would you rate the use of your smartphone?

- 1 - Rookie 
- 2

- 3

- 4

- 5 - Experient

8. How often do you play a game on your smartphone?

- More than once a day

- Once a day

- A few times a week

- Never

9. Do you use gestures to navigate your smartphone on a daily basis? If so, which ones?

10. How would you rate your visual acuity?

- Totally blind, with no light perception

- Low vision, with visual acuity less than $6 / 10$

- Moderate vision, with visual acuity between 6/12 and 6/60

- Moderate vision, with visual acuity above $6 / 12$ 


\section{Appendix F}

\section{Study - Informative Briefing}

We are inviting you to participate in our research study focused on understanding how games can be used as a method of discovery and practise of gestures on smartphones.

Before deciding, we would like to introduce you the details of this research, its motivation, its potential usefulness and the implications of your participation. A member of the research team will accompany you in reading this leaflet and will answer any questions you may have. If you have any questions, do not hesitate and contact us (g.ferreiralobo@gmail.com) with any questions you may want to ask.

\section{What is the study "Screen Reader Gesture and Practice Through Gaming"?}

This study aims to understand whether games have any effect in the way gestures are performed on smartphones and if they can serve as a method of discovery and training. Specifically, in this study we have developed a set of games that are focused on teaching three sets of gestures, from simple gestures to L-shaped gestures. The approach we took for our games is based on the gestures offered by the screenreader Google Talkback and we are looking to understand if the developed games will have any effect on the perception and ability to perform gestures, as well as if they are an effective method of practising them.

This study will last for six weeks. Before the first session you will be asked to complete a demographic questionnaire. Then, there will be a brief remote session, through any video or voice call application, in which you can ask any questions and get help installing the first game.

\section{Gesture collection}

Before playing any of our games for the first time you will be asked to complete a set of gestures practiced by the games, with more complex gestures. This set of gestures is related with the game you will be playing for the next two weeks. At the end of the two weeks, you will be asked to perform the same set of gestures you did at the beginning. The games will guide you through the process gesture collection.

Every two weeks 
You will be asked to play the game for a week, at least until you reach your daily goal, which corresponds to 5 game sessions. While you are playing, we will save your game sessions. At next week, if you want to continue playing, you can do so without having to comply with the 5 daily game sessions.

\section{Final remote interview}

At the end of this six-week period, you will be given a remote interview. The interview will last about 15 minutes and will consist of open-ended questions regarding your perspective on the games, your usage of your smartphone after before and after playing our games and the practise of the gestures. The audio from interview will be recorded and transcribed. Finally, after the interview we'll help you uninstall the games, if you want.

\section{Do I have to participate in this study?}

Participation in the study is completely voluntary. We will describe the study and present the content of this information leaflet, including details of your participation. If you agree to participate, you will sign a Consent Form. You will be provided with copies of this document and the Informed Consent Form.

\section{What if I want to drop out of the study?}

You are free to give up, at any time, without having to provide any reasons or explanations.

\section{What are the disadvantages and risks of participating?}

No associated risks are anticipated and the expectation of the research team is that the sessions in which participating is a pleasant experience for participants.

\section{What are the possible benefits of participating?}

According to our experience, people like to participate in studies that promote communication with scientists. Your involvement will help to understand whether games can be a method of learning and practicing gestures on smartphones. In addition, it will help understand if the games developed are capable of what we want to prove. Your participation also you will be rewarded with a $10 €$ voucher at the end of the study. If you drop out of the study this voucher will not be issued to you at any time.

\section{What happens when the study ends?}

The results of the study will be published in conferences and academic journals. If you want to know details of the results and implications of the study, we will send you a copy of the report of the study. 


\section{What if a problem occurs?}

If you have any concerns about any aspect of this study, you should speak to the researcher, André Rodrigues, who will do his best to clarify and answer your questions, by phone, 912128560 or email, afrodrigues@ @c.ul.pt. If you are unhappy or want to make a formal complaint, you can do so by contacting the Director of the Faculty of Sciences of the University of Lisbon [e-mail: direccao@fc.ul.pt].

\section{Will my information be kept confidential?}

Yes. We will follow all ethical and legal practices and all information about you will be treated absolutely confidential. To guarantee anonymity, personal records will only be available in their entirety, to the responsible investigator, and the members of the research team research will only have access to the data they need to know. If your data is used for publications or presentations, will be completely anonymous, without any reference, directly or indirectly to your identity. If photographs are taken, and it is our intention to use them in presentation, you will be asked for prior authorization. If it's available for us to use photos or videos for that purpose, we will first ask you to sign specific permissions for that purpose.

\section{Did the study go through a review process?}

In fact, this study was reviewed by the Ethics Committee for the Collection and Protection of Data Sciences (https://ciencias.ulisboa.pt/pt/prote\%C3\%A7\%C3\%A3ode-dados). This committee analyzed the study proposal, as well as all of its materials and raised no objections from an ethical point of view.

\section{Who can I contact in connection with this study?}

\begin{tabular}{|c|c|c|}
\hline Prof. Tiago Guerreiro & Prof. André Rodrigues & Gonçalo Lobo \\
Faculty of Sciences & Faculty of Sciences & Faculty of Sciences \\
University of Lisbon & University of Lisbon & University of Lisbon \\
tjvg@di.fc.ul.pt & afrodrigues@ fc.ul.pt & fc44870@ alunos.fc.ul.pt \\
& & 969149742 \\
\hline
\end{tabular}

Feel free to contact them in any matter related to this study. Thank you so much.

Thank you for taking the time to consider us and for considering participating in this study.

The Responsible Investigator, André Rodrigues 


\section{Appendix G}

\section{Study - Informed Consent Form}

1. I confirm that I have read and understood the information leaflet associated with the project.

2. I was given the opportunity to read and consider the information presented, and to ask questions, which have been answered satisfactorily.

3. I understand that my participation is voluntary and that I am free to drop out of the study in any time, without having to give any explanations and without any consequences.

4. I understand that the data collected during the study may be known to members of the research team, whenever necessary for the study. I authorize that team members have access to that data.

5. I understand that, should this investigation be published, all data will be kept anonymous and no information will be identifiable as being mine.

6. I would like the final report of the study to be sent to me. My e-mail address is:

7. I declare that I have not communicated any potential reason of any kind that constitutes a possible risk factor for my health or physical integrity.

8. I declare that I accept that my interviews are recorded on audio.

9. I declare that I make my decision entirely freely.

10. I agree to participate in this study. 


\section{Appendix H}

\section{Study - Codebook}

\begin{tabular}{|c|c|c|}
\hline Code/Label & Description & Example \\
\hline 1. Game & $\begin{array}{l}\text { What is played, how and where } \\
\text { it's played. }\end{array}$ & $\begin{array}{l}\text { "There was one who also } \\
\text { played a lot that was a card } \\
\text { game.." }\end{array}$ \\
\hline 1.1 Corda & Game Corda is mentioned. & "He likes the game Corda.." \\
\hline 1.2 Redes & $\begin{array}{l}\text { Game Guarda Redes is men- } \\
\text { tioned. }\end{array}$ & $\begin{array}{l}\text { "His favorite game is Guarda } \\
\text { Redes.." }\end{array}$ \\
\hline 1.3 Foguete & Game Foguete is mentioned. & $\begin{array}{l}\text { "And Foguete game is the most } \\
\text { complex of all and he had less } \\
\text { interest.." }\end{array}$ \\
\hline 1.4 Game Mode & A game mode is mentioned. & $\begin{array}{l}\text { "Go to the Remates Laterais } \\
\text { and it's there left then right.." }\end{array}$ \\
\hline 1.5 Other & $\begin{array}{l}\text { A specific game other than } \\
\text { Corda, Guarda Redes or } \\
\text { Foguete is mentioned. }\end{array}$ & $\begin{array}{l}\text { "There is a computer program } \\
\text { called PlayRoom.." }\end{array}$ \\
\hline 1.5 Platform & $\begin{array}{l}\text { A platform to play video games } \\
\text { is mentioned. (e.g specific con- } \\
\text { soles, computer, mobile) }\end{array}$ & $\begin{array}{l}\text { "I happen to have always liked } \\
\text { computer games.." }\end{array}$ \\
\hline 2. Gestures & $\begin{array}{l}\text { Gestures in general are men- } \\
\text { tioned. }\end{array}$ & $\begin{array}{l}\text { "Yes, the gestures I knew, the } \\
\text { gestures that you applied.." }\end{array}$ \\
\hline 2.1 Basic & A basic gesture is mentioned. & $\begin{array}{l}\text { "The best way to start is to } \\
\text { swipe left, right and finger ex- } \\
\text { ploration." }\end{array}$ \\
\hline $\begin{array}{ll}2.2 & \text { Back-and- } \\
\text { Forth } & \end{array}$ & $\begin{array}{l}\text { A back-and-forth gesture is } \\
\text { mentioned. }\end{array}$ & $\begin{array}{l}\text { "Sometimes I do right-left, or } \\
\text { left-right and when I check it is } \\
\text { a goal." }\end{array}$ \\
\hline 2.3 Angle & An angle gesture is mentioned. & $\begin{array}{l}\text { "When you slide your finger } \\
\text { from top to bottom and to the } \\
\text { right." }\end{array}$ \\
\hline $\begin{array}{l}\text { 3. Learning Ges- } \\
\text { ture }\end{array}$ & $\begin{array}{l}\text { The process of learning how } \\
\text { to perform a gesture is men- } \\
\text { tioned. }\end{array}$ & $\begin{array}{l}\text { "I learned to use them by using } \\
\text { Talkback.." }\end{array}$ \\
\hline
\end{tabular}




\begin{tabular}{|c|c|c|}
\hline 3.1 Tutorial & $\begin{array}{l}\text { Google Talkback tutorial is } \\
\text { mentioned. }\end{array}$ & $\begin{array}{l}\text { "I belong to this one about } \\
\text { Google Talkback, which now } \\
\text { doesn't have so much move- } \\
\text { ment.." }\end{array}$ \\
\hline 3.2 Mailing Lists & Mailing lists are mentioned. & $\begin{array}{l}\text { "They are those lists, through } \\
\text { Yahoo, now from Google. } \\
\text { They're like blogs, via emails." }\end{array}$ \\
\hline 3.3 Peers & $\begin{array}{l}\text { Assistance from peers is men- } \\
\text { tioned. }\end{array}$ & $\begin{array}{l}\text { "Some colleagues of mine at } \\
\text { work who started using and } \\
\text { asking, when they wanted to do } \\
\text { something." }\end{array}$ \\
\hline 3.4 Exploration & $\begin{array}{l}\text { Process of learning without } \\
\text { asking for help, i.e trial and er- } \\
\text { ror, experimenting. }\end{array}$ & $\begin{array}{l}\text { "A person has to go exploring } \\
\text { and understand how it works." }\end{array}$ \\
\hline $\begin{array}{l}\text { 4. Accessible } \\
\text { Tools }\end{array}$ & $\begin{array}{l}\text { Accessible tools or methods } \\
\text { for smartphones or computers } \\
\text { mentioned. }\end{array}$ & $\begin{array}{l}\text { "We started with the computer, } \\
\text { by introducing the keyboard } \\
\text { with feedback." }\end{array}$ \\
\hline 5. Barrier & $\begin{array}{l}\text { What makes gaming or han- } \\
\text { dling accessible tools diffi- } \\
\text { cult/more complicated. }\end{array}$ & $\begin{array}{l}\text { "Tiny to fit in my pocket and } \\
\text { discreet because I thought a } \\
\text { big phone at the time was a } \\
\text { reason to be robbed quickly.." }\end{array}$ \\
\hline 5.1 Lack & $\begin{array}{l}\text { Lack of accessibility in a tool } \\
\text { or lack of accessibility in gen- } \\
\text { eral is mentioned. }\end{array}$ & $\begin{array}{l}\text { "Because even in the play } \\
\text { store, there is no accessible } \\
\text { game.." }\end{array}$ \\
\hline 5.2 Expensive & $\begin{array}{l}\text { Cost of an accessible tool is } \\
\text { mentioned. }\end{array}$ & $\begin{array}{l}\text { "There are mobile phones for } \\
\text { sale which have keys, Android } \\
\text { but with keys, which cost } 300 \\
€ . . "\end{array}$ \\
\hline 5.3 Unawareness & $\begin{array}{l}\text { Unaware of accessible } \\
\text { games/accessible tools or } \\
\text { accessibility options is men- } \\
\text { tioned. }\end{array}$ & $\begin{array}{l}\text { "But at least to my knowledge } \\
\text { there is no software that can } \\
\text { help him for now." }\end{array}$ \\
\hline 6. Expertise & $\begin{array}{l}\text { The expertise of a user is men- } \\
\text { tioned. }\end{array}$ & $\begin{array}{l}\text { "Therefore, at the level of ex- } \\
\text { perienced people the interest of } \\
\text { the game will be to play.." }\end{array}$ \\
\hline $\begin{array}{l}\text { 6.1 Less Experi- } \\
\text { enced }\end{array}$ & $\begin{array}{l}\text { Games developed are men- } \\
\text { tioned as more suited for less } \\
\text { experienced players. }\end{array}$ & $\begin{array}{l}\text { "For those who are at the be- } \\
\text { ginning, they will enter at the } \\
\text { very beginning, it really is a } \\
\text { good way to train the ges- } \\
\text { tures.." }\end{array}$ \\
\hline 6.2 Proficient & $\begin{array}{l}\text { Games developed are men- } \\
\text { tioned as more suited for more } \\
\text { experienced players. }\end{array}$ & $\begin{array}{l}\text { "Now, for those who are al- } \\
\text { ready more advanced, they are } \\
\text { already so internalized, the } \\
\text { gestures, it's already intuitive." }\end{array}$ \\
\hline
\end{tabular}




\begin{tabular}{|c|c|c|}
\hline 7. Feedback & $\begin{array}{l}\text { Game output is discussed (in- } \\
\text { formation given during game- } \\
\text { play). }\end{array}$ & $\begin{array}{l}\text { "The only thing that I would try } \\
\text { to improve in the three games } \\
\text { would be to put the explanation } \\
\text { of the gestures in the menu." }\end{array}$ \\
\hline 7.1 Audio & Audio feedback is discussed. & $\begin{array}{l}\text { "I don't know if it was at the } \\
\text { sound level.." }\end{array}$ \\
\hline 7.2 Visual & Visual feedback is discussed. & $\begin{array}{l}\text { "Although there is a time when } \\
\text { it seems like } 3 \text { are coming at the } \\
\text { same time.." }\end{array}$ \\
\hline 8. Mechanic & $\begin{array}{l}\text { A specific game mechanic or } \\
\text { feature is mentioned. }\end{array}$ & $\begin{array}{l}\text { "For example, defending a ball } \\
\text { that comes from above-left has } \\
\text { to do left-up to be able to de- } \\
\text { fend." }\end{array}$ \\
\hline 9. Complexity & Game complexity is discussed. & $\begin{array}{l}\text { "Corda was the easiest to ex- } \\
\text { plain to him, how it worked be- } \\
\text { cause it didn't have so many } \\
\text { inputs, it was easier to under- } \\
\text { stand." }\end{array}$ \\
\hline 9.1 Simple & $\begin{array}{l}\text { Game or mechanic is men- } \\
\text { tioned as simple. }\end{array}$ & $\begin{array}{l}\text { "Corda is the simplest, it's a } \\
\text { matter of being more focused, } \\
\text { it's a simple game." }\end{array}$ \\
\hline 9.2 Complex & $\begin{array}{l}\text { Game or mechanic is men- } \\
\text { tioned as complex. }\end{array}$ & $\begin{array}{l}\text { "It is complicated because it is } \\
\text { not that easy for us to go left, } \\
\text { up, be able to defend both at } \\
\text { the same time." }\end{array}$ \\
\hline 10. Competence & $\begin{array}{l}\text { Comments regarding compe- } \\
\text { tence during the game, being } \\
\text { effective while playing. }\end{array}$ & $\begin{array}{l}\text { "In the rope game, he already } \\
\text { makes } 40 \text { or } 50 \text { jumps." }\end{array}$ \\
\hline 11. Difficulty & $\begin{array}{l}\text { Difficulty of performing ges- } \\
\text { tures and difficulty of perform- } \\
\text { ing gestures while playing is } \\
\text { mentioned. }\end{array}$ & $\begin{array}{l}\text { "Some gestures are easy, oth- } \\
\text { ers turn out to be more diff- } \\
\text { cult." }\end{array}$ \\
\hline 11.1 Easy & $\begin{array}{l}\text { Gestures mentioned are easy to } \\
\text { perform while playing. }\end{array}$ & $\begin{array}{l}\text { "Now, Corda is also just per- } \\
\text { forming two taps.." }\end{array}$ \\
\hline 11.2 Hard & $\begin{array}{l}\text { Gestures mentioned are diffi- } \\
\text { cult to perform while playing. }\end{array}$ & $\begin{array}{l}\text { "It is complicated because it is } \\
\text { not that easy for us to go left, } \\
\text { up, to be able to defend both at } \\
\text { the same time." }\end{array}$ \\
\hline 12. Reaction & $\begin{array}{l}\text { A reaction to something is de- } \\
\text { scribed. }\end{array}$ & $\begin{array}{l}\text { "For example, the game that I } \\
\text { play the most is the Guarda Re- } \\
\text { des." }\end{array}$ \\
\hline 12.1 Frustrating & $\begin{array}{l}\text { Something is highlighted as } \\
\text { frustrating. }\end{array}$ & $\begin{array}{l}\text { "I can't figure out which way to } \\
\text { go.." }\end{array}$ \\
\hline
\end{tabular}




\begin{tabular}{|c|c|c|}
\hline 12.2 Weariness & $\begin{array}{l}\text { Something is highlighted as } \\
\text { tiresome. }\end{array}$ & $\begin{array}{l}\text { "But he gets a little tired after } \\
\text { having to have to play with the } \\
\text { phones." }\end{array}$ \\
\hline 12.3 Engaging & $\begin{array}{l}\text { Something is highlighted as en- } \\
\text { gaging. }\end{array}$ & $\begin{array}{l}\text { "But that also goes with the } \\
\text { game itself and is a funny chal- } \\
\text { lenge." }\end{array}$ \\
\hline 12.4 Confusing & $\begin{array}{l}\text { Something is highlighted as } \\
\text { confusing. }\end{array}$ & $\begin{array}{l}\text { "It turns out to be confusing } \\
\text { having to dodge from one side } \\
\text { or the other." }\end{array}$ \\
\hline 13. Inclusion & $\begin{array}{l}\text { Game or experience is regarded } \\
\text { as inclusive or exclusive. }\end{array}$ & $\begin{array}{l}\text { "I can see him giving the } \\
\text { phone, pass a level, pass it to a } \\
\text { friend and pass another level.." }\end{array}$ \\
\hline 14. Autonomy & $\begin{array}{l}\text { Autonomy is mentioned as a } \\
\text { consequence of using accessi- } \\
\text { ble tools. }\end{array}$ & $\begin{array}{l}\text { "Yes, Jisu, the interaction is } \\
\text { much faster, it has nothing to } \\
\text { do, nothing, nothing at all." }\end{array}$ \\
\hline 15. Ability & $\begin{array}{l}\text { Ability of navigating the smart- } \\
\text { phone is mentioned. }\end{array}$ & $\begin{array}{l}\text { "He already knew how to work } \\
\text { the phone, with Talkback." }\end{array}$ \\
\hline $\begin{array}{l}\text { 16. Functional- } \\
\text { ity }\end{array}$ & $\begin{array}{l}\text { A certain Google Talkback } \\
\text { functionality is mentioned. }\end{array}$ & $\begin{array}{l}\text { "I don't happen to remember } \\
\text { any function on Talkback that } \\
\text { has a left-right function with- } \\
\text { out lifting a finger.." }\end{array}$ \\
\hline 17. Educational & $\begin{array}{l}\text { Potential for educational pur- } \\
\text { poses is recognized. }\end{array}$ & $\begin{array}{l}\text { "I noticed that the games were } \\
\text { an asset in terms of exploring } \\
\text { gestures.." }\end{array}$ \\
\hline 18. Bug & $\begin{array}{l}\text { A bug or technical problem } \\
\text { with a game is reported. }\end{array}$ & $\begin{array}{l}\text { "It gives the impression that it } \\
\text { interprets a gesture that I didn't } \\
\text { even do." }\end{array}$ \\
\hline 19. Suggestions & $\begin{array}{l}\text { Suggestions made by partici- } \\
\text { pants. }\end{array}$ & $\begin{array}{l}\text { "Similarly to Foguete, perhaps } \\
\text { introducing levels where more } \\
\text { time is allowed." }\end{array}$ \\
\hline
\end{tabular}

Table H.1: Study - Codebook 


\section{Appendix I}

\section{Study - Themes Outline}

\begin{tabular}{|c|c|c|}
\hline Theme & Summary & Informing Codes \\
\hline $\begin{array}{l}\text { Exclusion from } \\
\text { Playing }\end{array}$ & $\begin{array}{l}\text { People with visual impairments have } \\
\text { limited choice in terms of games to play, } \\
\text { in terms of accessibility or game's ideas } \\
\text { in general; Accessible technologies of- } \\
\text { ten do not offer accessibility to the full } \\
\text { extent, forcing visually impaired people } \\
\text { to search for other alternatives. }\end{array}$ & $\begin{array}{l}\text { Accessible Tools, } \\
\text { Barrier, Frustrating, } \\
\text { Weariness, Lack, } \\
\text { Expensive, Unaware- } \\
\text { ness, Autonomy }\end{array}$ \\
\hline $\begin{array}{l}\text { Gesture Learn- } \\
\text { ing and Percep- } \\
\text { tion }\end{array}$ & $\begin{array}{l}\text { How people with visual impairments } \\
\text { learn gestures to navigate their smart- } \\
\text { phones; Which aspects of that learning } \\
\text { are common; Which are the gestures vi- } \\
\text { sually impaired users become more fa- } \\
\text { miliarized with.. }\end{array}$ & $\begin{array}{l}\text { Learning Gesture, Tu- } \\
\text { torial, Mailing Lists, } \\
\text { Peers, Exploration, } \\
\text { Gestures, Basic, } \\
\text { Back-and-Forth, An- } \\
\text { gle, Functionality, } \\
\text { Ability }\end{array}$ \\
\hline $\begin{array}{l}\text { Discovery } \\
\text { Through Enter- } \\
\text { tainment }\end{array}$ & $\begin{array}{l}\text { Feedback of the games; How games } \\
\text { were seen as a method of entertainment; } \\
\text { How that entertainment has influenced } \\
\text { the practise of gestures; Games were } \\
\text { seen as pleasurable for learning ges- } \\
\text { tures. }\end{array}$ & 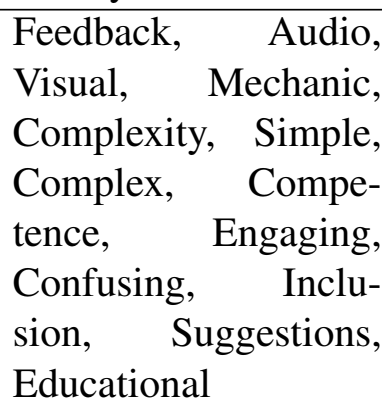 \\
\hline $\begin{array}{l}\text { Gesture Practice } \\
\text { and Discovery }\end{array}$ & $\begin{array}{l}\text { Discovery of gestures leads to auton- } \\
\text { omy and inclusion, for less experienced } \\
\text { players; Engaging games lead to a good } \\
\text { method of practise and discovery of ges- } \\
\text { tures. }\end{array}$ & $\begin{array}{l}\text { Experience, Less Ex- } \\
\text { perienced, Proficient, } \\
\text { Difficulty, Easy, Hard, } \\
\text { Engaging, Autonomy, } \\
\text { Ability, Inclusion }\end{array}$ \\
\hline
\end{tabular}

Table I.1: Study - Themes Outline 



\section{Bibliography}

[1] Lisa Anthony, YooJin Kim, and Leah Findlater. Analyzing user-generated youtube videos to understand touchscreen use by people with motor impairments. In Proceedings of the SIGCHI Conference on Human Factors in Computing Systems, pages 1223-1232. ACM, 2013.

[2] Matthew T Atkinson, Sabahattin Gucukoglu, Colin HC Machin, and Adrian E Lawrence. Making the mainstream accessible: redefining the game. In Proceedings of the 2006 ACM SIGGRAPH symposium on Videogames, pages 21-28. ACM, 2006.

[3] Audio Game Hub. Audio game hub, 2018. http://www .audiogamehub. com/games/, Last accessed on 2020-01-09.

[4] Matthew N Bonner, Jeremy T Brudvik, Gregory D Abowd, and W Keith Edwards. No-look notes: accessible eyes-free multi-touch text entry. In International Conference on Pervasive Computing, pages 409-426. Springer, 2010.

[5] Maria Claudia Buzzi, Marina Buzzi, Barbara Leporini, and Amaury Trujillo. Exploring visually impaired people's gesture preferences for smartphones. In Proceedings of the 11th Biannual Conference on Italian SIGCHI Chapter, pages 94-101. ACM, 2015.

[6] Jaime Carvalho, Tiago Guerreiro, Luis Duarte, and Luis Carriço. Audio-based puzzle gaming for blind people. In Proceedings of the Mobile Accessibility Workshop at MobileHCI (MOBACC), 2012.

[7] Creative Heroes. Audio games.net, 2018. https://audiogames.net/ search-games/, Last accessed on 2020-01-09.

[8] Rafael Jeferson Pezzuto Damaceno, Juliana Cristina Braga, and Jesús Pascual MenaChalco. Mobile device accessibility for the visually impaired: problems mapping and recommendations. Universal Access in the Information Society, 17(2):421-435, 2018. 
[9] Brian Frey, Caleb Southern, and Mario Romero. Brailletouch: mobile texting for the visually impaired. In International Conference on Universal Access in HumanComputer Interaction, pages 19-25. Springer, 2011.

[10] Johnny Friberg and Dan Gärdenfors. Audio games: new perspectives on game audio. In Proceedings of the 2004 ACM SIGCHI International Conference on Advances in computer entertainment technology, pages 148-154. ACM, 2004.

[11] Galaxy Laboratory. Shadowrine official site, 2009. http: / / www . mm-galabo . com/sr/index_en.php, Last accessed on 2020-01-10.

[12] Lee Garber. Game accessibility: enabling everyone to play. IEEE Annals of the History of Computing, 46(06):14-18, 2013.

[13] Franco Eusébio Garcia and Vânia Paula de Almeida Neris. Design guidelines for audio games. In International Conference on Human-Computer Interaction, pages 229-238. Springer, 2013.

[14] James Paul Gee. What video games have to teach us about learning and literacy. Computers in Entertainment (CIE), 1(1):20-20, 2003.

[15] Eitan Glinert and Lonce Wyse. Audiodyssey: an accessible video game for both sighted and non-sighted gamers. In Proceedings of the 2007 conference on Future Play, pages 251-252. ACM, 2007.

[16] GMA. Shades of doom, 2008. https://www.gmagames.com/sod.html, Last accessed on 2020-01-10.

[17] David Gonçalves, André Rodrigues, and Tiago Guerreiro. Playing with others: Depicting multiplayer gaming experiences of people with visual impairments. In The 22nd International ACM SIGACCESS Conference on Computers and Accessibility, pages $1-12,2020$.

[18] Dimitris Grammenos, Anthony Savidis, and Constantine Stephanidis. Ua-chess: A universally accessible board game. In Universal Access in HCI: Exploring New Interaction Environments-Proc. 11 th Int. Conf. on Human-Computer Interaction (HCI International 2005), volume 7, 2005.

[19] Dimitris Grammenos, Anthony Savidis, and Constantine Stephanidis. Designing universally accessible games. Computers in Entertainment (CIE), 7(1):8, 2009.

[20] William Grussenmeyer and Eelke Folmer. Accessible touchscreen technology for people with visual impairments: a survey. ACM Transactions on Accessible Computing (TACCESS), 9(2):6, 2017. 
[21] Tiago Guerreiro, Paulo Lagoá, Hugo Nicolau, Daniel Gonçalves, and Joaquim A Jorge. From tapping to touching: Making touch screens accessible to blind users. IEEE MultiMedia, 15(4):48-50, 2008.

[22] Includification. Includification, 2012. https://wWw. includification. com, Last accessed on 2012-16.

[23] J. Kitchen. Mach 1 car racing, 2015. https://www.agarchive.net/ pages/devs/kitchensinc.html, Last accessed on 2020-01-10.

[24] Hesham M Kamel, Patrick Roth, and Rashmi Sinha. Graphics and user's exploration via simple sonics (guess): providing interrelational representation of objects in a non-visual environment. Georgia Institute of Technology, 2001.

[25] Shaun K Kane, Jeffrey P Bigham, and Jacob O Wobbrock. Slide rule: making mobile touch screens accessible to blind people using multi-touch interaction techniques. In Proceedings of the 10th international ACM SIGACCESS conference on Computers and accessibility, pages 73-80. ACM, 2008.

[26] Shaun K Kane, Chandrika Jayant, Jacob O Wobbrock, and Richard E Ladner. Freedom to roam: a study of mobile device adoption and accessibility for people with visual and motor disabilities. In Proceedings of the 11th international ACM SIGACCESS conference on Computers and accessibility, pages 115-122. ACM, 2009.

[27] Shaun K Kane, Meredith Ringel Morris, Annuska Z Perkins, Daniel Wigdor, Richard E Ladner, and Jacob O Wobbrock. Access overlays: improving non-visual access to large touch screens for blind users. In Proceedings of the 24th annual ACM symposium on User interface software and technology, pages 273-282. ACM, 2011.

[28] Shaun K Kane, Meredith Ringel Morris, and Jacob O Wobbrock. Touchplates: lowcost tactile overlays for visually impaired touch screen users. In Proceedings of the 15th International ACM SIGACCESS Conference on Computers and Accessibility, page 22. ACM, 2013.

[29] Shaun K Kane, Jacob O Wobbrock, and Richard E Ladner. Usable gestures for blind people: understanding preference and performance. In Proceedings of the SIGCHI Conference on Human Factors in Computing Systems, pages 413-422. ACM, 2011.

[30] Joy Kim and Jonathan Ricaurte. Tapbeats: accessible and mobile casual gaming. In The proceedings of the 13th international ACM SIGACCESS conference on Computers and accessibility, pages 285-286. ACM, 2011.

[31] Jeremy Lee, Kathleen Luchini, Benjamin Michael, Cathie Norris, and Elliot Soloway. More than just fun and games: Assessing the value of educational video 
games in the classroom. In CHI'04 extended abstracts on Human factors in computing systems, pages 1375-1378. ACM, 2004.

[32] Barbara Leporini and Marion Hersh. Games for the rehabilitation of disabled people. In Proceedings of the 4th Workshop on ICTs for Improving Patients Rehabilitation Research Techniques, pages 109-112, 2016.

[33] Conor Linehan, Ben Kirman, Shaun Lawson, and Gail Chan. Practical, appropriate, empirically-validated guidelines for designing educational games. In Proceedings of the SIGCHI conference on human factors in computing systems, pages 1979-1988. ACM, 2011.

[34] M. Shultz. Blindfold racer, 2014. https://www.blindfoldracer.com, Last accessed on 2020-01-10.

[35] Phillip McClean, Bernhardt Saini-Eidukat, Donald Schwert, Brian Slator, and Alan White. Virtual worlds in large enrollment science classes significantly improve authentic learning. In in: Proceedings of the 12th International Conference on College Teaching and Learning, Center for the Advancement of Teaching and Learning. Citeseer, 2001.

[36] Joanne McElligott and Lieselotte Van Leeuwen. Designing sound tools and toys for blind and visually impaired children. In Proceedings of the 2004 conference on Interaction design and children: building a community, pages 65-72. ACM, 2004.

[37] Daniel Miller, Aaron Parecki, and Sarah A Douglas. Finger dance: a sound game for blind people. In Proceedings of the 9th international ACM SIGACCESS conference on Computers and accessibility, pages 253-254. ACM, 2007.

[38] Lauren R Milne, Cynthia L Bennett, and Richard E Ladner. Vbghost: a braillebased educational smartphone game for children. In Proceedings of the 15th International ACM SIGACCESS Conference on Computers and Accessibility, page 75. ACM, 2013.

[39] Maia Naftali and Leah Findlater. Accessibility in context: understanding the truly mobile experience of smartphone users with motor impairments. In Proceedings of the 16th international ACM SIGACCESS conference on Computers \& accessibility, pages 209-216. ACM, 2014.

[40] Hugo Nicolau, Kyle Montague, Tiago Guerreiro, André Rodrigues, and Vicki L Hanson. Typing performance of blind users: An analysis of touch behaviors, learning effect, and in-situ usage. In Proceedings of the 17th International ACM SIGACCESS Conference on Computers \& Accessibility, pages 273-280. ACM, 2015. 
[41] Uran Oh, Shaun K Kane, and Leah Findlater. Follow that sound: using sonification and corrective verbal feedback to teach touchscreen gestures. In Proceedings of the 15th International ACM SIGACCESS Conference on Computers and Accessibility, page 13. ACM, 2013.

[42] João Oliveira, Tiago Guerreiro, Hugo Nicolau, Joaquim Jorge, and Daniel Gonçalves. Blind people and mobile touch-based text-entry: acknowledging the need for different flavors. In The proceedings of the 13th international ACM SIGACCESS conference on Computers and accessibility, pages 179-186. ACM, 2011.

[43] Roland Ossmann and Klaus Miesenberger. Guidelines for the development of accessible computer games. In International Conference on Computers for Handicapped Persons, pages 403-406. Springer, 2006.

[44] John R Porter and Julie A Kientz. An empirical study of issues and barriers to mainstream video game accessibility. In Proceedings of the 15th international ACM SIGACCESS conference on computers and accessibility, page 3. ACM, 2013.

[45] Richard L Potter, Linda J Weldon, and Ben Shneiderman. Improving the accuracy of touch screens: an experimental evaluation of three strategies. In Proceedings of the SIGCHI conference on Human factors in computing systems, pages 27-32. ACM, 1988.

[46] Marc Prensky. Fun, play and games: What makes games engaging. Digital gamebased learning, 5(1):5-31, 2001.

[47] Yosra Rekik, Radu-Daniel Vatavu, and Laurent Grisoni. Understanding users' perceived difficulty of multi-touch gesture articulation. In Proceedings of the 16th International Conference on Multimodal Interaction, pages 232-239. ACM, 2014.

[48] André Rodrigues, Kyle Montague, Hugo Nicolau, and Tiago Guerreiro. Getting smartphones to talkback: understanding the smartphone adoption process of blind users. In Proceedings of the 17th International ACM SIGACCESS Conference on Computers \& Accessibility, pages 23-32. ACM, 2015.

[49] André Rodrigues, Hugo Nicolau, Kyle Montague, Luís Carriço, and Tiago Guerreiro. Effect of target size on non-visual text-entry. In Proceedings of the 18th International conference on human-computer interaction with mobile devices and services, pages 47-52. ACM, 2016.

[50] André Rodrigues, André Santos, Kyle Montague, and Tiago Guerreiro. Improving smartphone accessibility with personalizable static overlays. In Proceedings of the 19th International ACM SIGACCESS Conference on Computers and Accessibility, pages 37-41. ACM, 2017. 
[51] André Rodrigues, Hugo Nicolau, Kyle Montague, João Guerreiro, and Tiago Guerreiro. Open challenges of blind people using smartphones, 2019.

[52] Emmanouel Rovithis, Andreas Floros, Andreas Mniestris, and Nikolas Grigoriou. Audio games as educational tools: Design principles and examples. In 2014 IEEE Games Media Entertainment, pages 1-8. IEEE, 2014.

[53] RS Games. Rs games, 2009. http://rsgames.org/, Last accessed on 202001-09.

[54] Jaime Sánchez, Mauricio Sáenz, and Jose Miguel Garrido. Usability of a multimodal video game to improve navigation skills for blind children. ACM Transactions on Accessible Computing (TACCESS), 3(2):7, 2010.

[55] Frode Eika Sandnes, Tek Beng Tan, Anders Johansen, Edvin Sulic, Eirik Vesterhus, and Eirik Rud Iversen. Making touch-based kiosks accessible to blind users through simple gestures. Universal Access in the Information Society, 11(4):421-431, 2012.

[56] Brian A Smith and Shree K Nayar. The rad: making racing games equivalently accessible to people who are blind. In Proceedings of the 2018 CHI conference on human factors in computing systems, page 516. ACM, 2018.

[57] Donggil Song, Arafeh Karimi, and Paul Kim. Toward designing mobile games for visually challenged children. In Proceeding of the International Conference on eEducation, Entertainment and e-Management, pages 234-238. IEEE, 2011.

[58] Jing Su, Alyssa Rosenzweig, Ashvin Goel, Eyal de Lara, and Khai N Truong. Timbremap: enabling the visually-impaired to use maps on touch-enabled devices. In Proceedings of the 12th international conference on Human computer interaction with mobile devices and services, pages 17-26, 2010.

[59] Sue Targett and Mikael Fernstrom. Audio games: Fun for all? all for fun! Georgia Institute of Technology, 2003.

[60] Shari Trewin, Cal Swart, and Donna Pettick. Physical accessibility of touchscreen smartphones. In Proceedings of the 15th International ACM SIGACCESS Conference on Computers and Accessibility, page 19. ACM, 2013.

[61] Thomas Westin. Game accessibility case study: Terraformers-a real-time 3d graphic game. In Proceedings of the 5th International Conference on Disability, Virtual Reality and Associated Technologies, ICDVRAT, 2004.

[62] Mike Wu and Ravin Balakrishnan. Multi-finger and whole hand gestural interaction techniques for multi-user tabletop displays. In Proceedings of the 16th annual ACM symposium on User interface software and technology, pages 193-202. ACM, 2003. 
[63] Bei Yuan and Eelke Folmer. Blind hero: enabling guitar hero for the visually impaired. In Proceedings of the 10th international ACM SIGACCESS conference on Computers and accessibility, pages 169-176. ACM, 2008.

[64] BRANNON Zahand. Making video games accessible: business justifications and design considerations. MSDN Library Technical Articles. Accessed, 6, 2007. 